\begin{tabular}{|l|l|}
\hline $\begin{array}{l}\text { 2. To: (Receiving organization) } \\
\text { Distribution }\end{array}$ & $\begin{array}{l}\text { 3. From: (Originating Organization) } \\
\text { 300 Area LEF Engineering }\end{array}$ \\
\hline $\begin{array}{l}\text { 5. Proj./Prog./Dept./Div.: } \\
\text { 300A Liquid Effluent Faci1. }\end{array}$ & $\begin{array}{l}\text { 6. Design Authority/ Design Agent/Cog. } \\
\text { Engr.: } \\
\text { R. T. Stordeur }\end{array}$ \\
\hline $\begin{array}{l}\text { 8. Originator Remarks: } \\
\text { For final approval and release to meet FY } 1998 \text { Performance }\end{array}$ \\
Agreement (PA) WM 5.1.1
\end{tabular}

[] Yes

[x] No
11. Receiver Remarks:

11A. Design Baseline Document?

4. Related EDT No.: 618208

7. Purchase Order No.:

$$
N / A
$$

9. Equip./Component No.: $\mathrm{N} / \mathrm{A}$

10. System/Bldg./Facility: 340 Complex

12. Major Assin. Dwg. No.: N/A

13. Permit/Permit Application No.: N/A

14. Required Response Date: JuTy 2, 1998

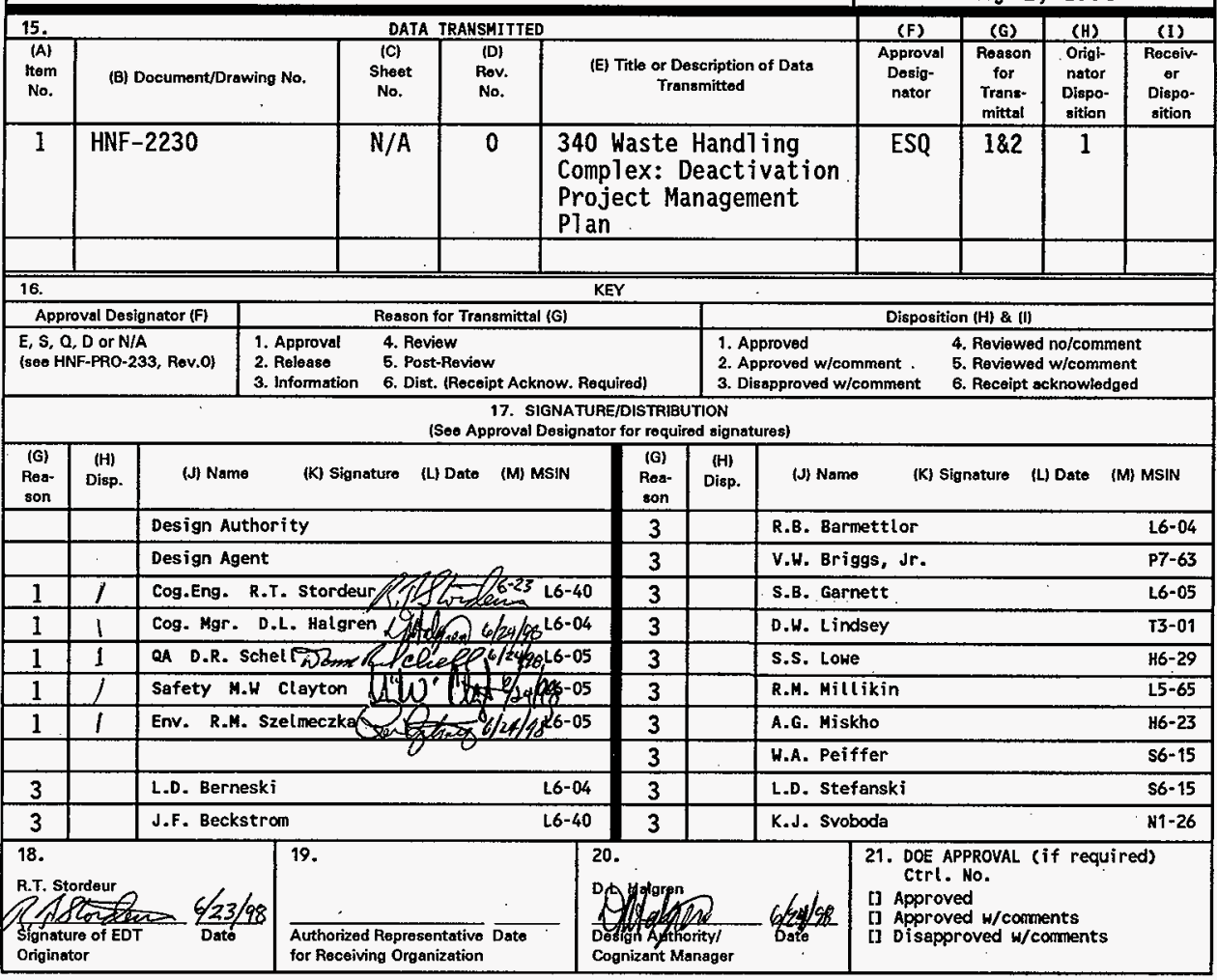


HNF-2230, Rev. 0

\title{
340 Waste Handling Complex: Deactivation Project Management Plan
}

\author{
R.T. Stordeur, J.F. Beckstrom (CE\&ES) \\ Waste Management Federal Services of Hanford Inc., Richland, WA 99352 \\ U.S. Department of Energy Contract DE-AC06-96RL13200
}

EDT: 618209

Org. Code: 32330

B\&R Code: EW3130020
UC: 2050

Charge Code: A4G1C

Total Pages: 126

Key Words: 340 Facility, 340 Complex, radioactive liquid waste system, RLWS, retention process sewer, RPS, 307 basins, waste storage tanks, 300 Area, deactivation, shut-down, pre-decommissioning, transition.

Abstract: This document provides an overview of the strategy for deactivating the 340 Waste Handling Complex within Hanford's 300 Area. The plan covers the period from the pending September 30,1998 cessation of voluntary radioactive liquid waste (RLW) transfers to the 340 Complex, until such time that those portions of the 340 Complex that remain active beyond September 30, 1998, specifically, the Retention Process Sewer (RPS), can also be shut down and deactivated. Specific activities are detailed and divided into two phases. Phase I ends in 2001 after the core RLW systems have been deactivated. Phase II covers the subsequent interim surveillance of deactivated and stand-by components during the period of continued RPS operation, through the final transfer of the entire 340 Complex to the Environmental Restoration Contractor. One of several possible scenarios was postulated and developed as a budget and schedule planning case.

TRADEMARK DISCLAIMER. Reference herein to any specific commercial product, process, or service by trade name, trademark, manufacturer, or otherwise, does not necessarily constitute or imply its endorsement, recommendation, or favoring by the United States Government or any agency thereof or its contractors or subcontractors.

Printed in the United States of America. To obtain copies of this document, contact: Document Control Services, P.O. Box 950, Mailstop H6-08, Richland WA 99352, Phone (509) 372-2420 Fax (509) 376-4989.
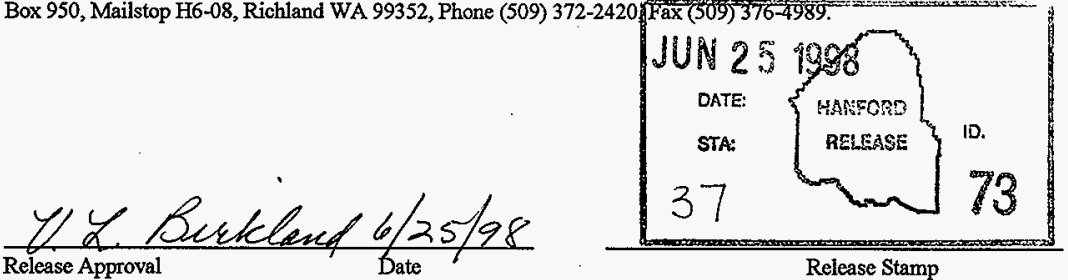

Release Stamp

\section{Approved for Public Release}


HNF-2230 Rev. 0

This page intentionally without substantive content. 


\title{
340 Waste Handling Complex: Deactivation Project Management Plan
}

Prepared for Performance Agreement WM 5.1.1

\author{
July, 1998
}

J.F. Beckstrom, Jr.

Columbia Energy and Environmental Services, Inc.

$$
\text { R.T. Stordeur }
$$

Waste Management Federal Services of Hanford, Inc. 300 Area Liquid Effluent Facilities 
HNF-2230 Rev. 0

This page intentionally without substantive content. 
HNF-2230 Rev. 0

TABLE OF CONTENTS

ABBREVIATIONS, ACRONYMS AND INITIALISMS $\ldots \ldots \ldots \ldots \ldots \ldots \ldots$ vi

ACKNOWLEDGMENTS $\ldots \ldots \ldots \ldots \ldots \ldots \ldots \ldots \ldots \ldots \ldots \ldots \ldots$ ix

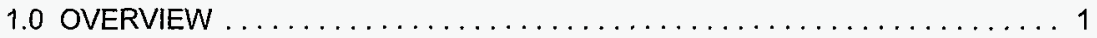

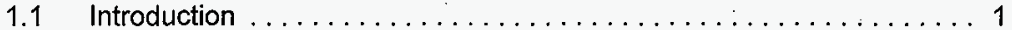

1.2 Purpose ......................... 4

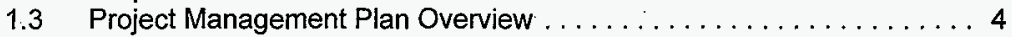

1.4 Assumptions .......................

1.5 Uncertainties ............................ 6

1.5.1 Parallel Negotiations with Regulators $\ldots \ldots \ldots \ldots \ldots \ldots \ldots 7$

1.5.2 Budgetary Considerations $\ldots \ldots \ldots \ldots \ldots \ldots \ldots \ldots \ldots$

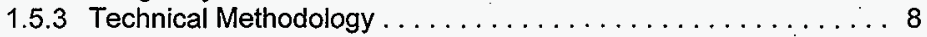

1.5.4 Scheduling Considerations . ................. 9

1.6340 Complex Description ..................... 9

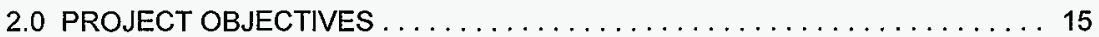

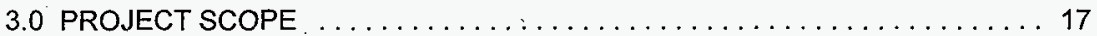

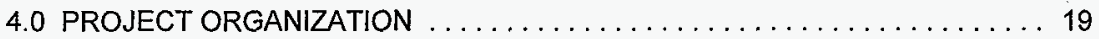

4.1 Project Management ......................... 19

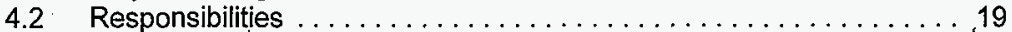

4.2.1 Liquid Effluent, Process Engineering ............. 19

4.2.2 Liquid Effluent, 340 Waste Handling Facility Operations . . . . . 19

4.2.3 Liquid Effluent, Work Control and Maintenance ... . . . . . . 19

4.2.4 Liquid Effluent, Facility Safety ................... 19

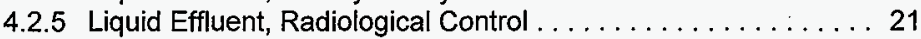

4.2.6 Liquid Effluent, Environmental Compliance ........... 21

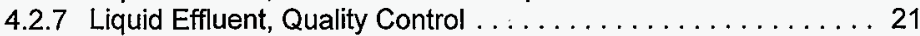

4.2.8 Environmental Services .................... 21

4.2.9 Strategic Planning and Generator Services .......... 21

5.0 MANAGEMENT AND CONTROL $\ldots \ldots \ldots \ldots \ldots \ldots \ldots \ldots \ldots \ldots \ldots$

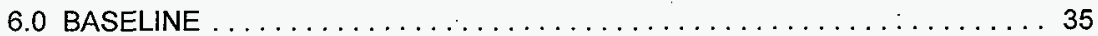

7.0 ENDPOINTS SUMMARY $\ldots \ldots \ldots \ldots \ldots \ldots \ldots \ldots \ldots \ldots \ldots \ldots \ldots \ldots \ldots$

$7.1 \quad$ Background $\ldots \ldots \ldots \ldots \ldots \ldots \ldots \ldots \ldots \ldots \ldots \ldots \ldots \ldots \ldots \ldots \ldots$

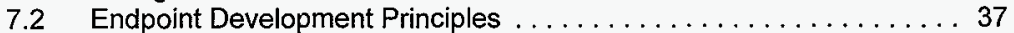

7.3 Endpoint Development Methodology $\ldots \ldots \ldots \ldots \ldots \ldots \ldots \ldots, \ldots \ldots$

7.4 Endpoint Administration $\ldots \ldots \ldots \ldots \ldots \ldots \ldots \ldots \ldots \ldots \ldots \ldots \ldots \ldots$

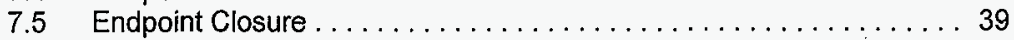

7.6 Administrative Endpoints and Turnover Package . . . . . . . . . 40 


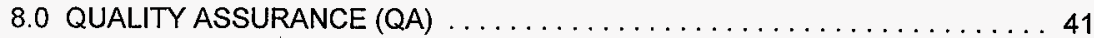

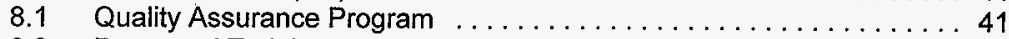

8.2 Personnel Training and Qualification $\ldots \ldots \ldots \ldots \ldots \ldots \ldots \ldots 41$

8.3 Document and Records Control ................... 42

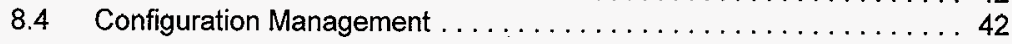

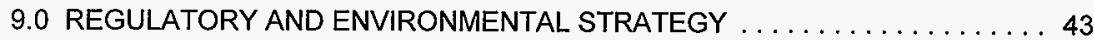

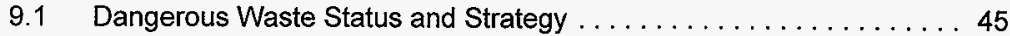

9.1.1 Regulatory Status of the 340 Complex ............ 45

9.1 .2340 Complex Closure Strategy . . . . . . . . . . . . . . . 46

9.2 Tri-Party Agreement Milestones $\ldots \ldots \ldots \ldots \ldots \ldots \ldots \ldots \ldots \ldots$

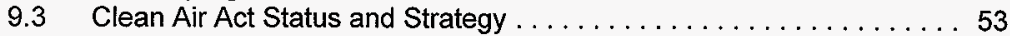

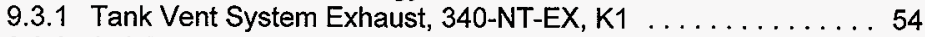

9.3.2 340-B East Ventilation Stack, 340-B-Building, K2 ....... 54

9.3.3 340 Building Stack, 340-Decon, K3 . . . . . . . . . . . . 54

9.4 Clean Water Act and Safe Drinking Water Act Status and Strategy . . 55

9.5 National Environmental Policy Act (NEPA) and State Environmental Policy Act (SEPA) and Endangered Species Act (ESA) Status and Strategy . 55

10.0 DEACTIVATION PROJECT INTEGRATED SAFETY STRATEGY . . . . . . . . 59

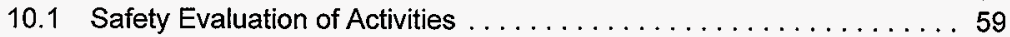

10.1.1 Safety Basis Documentation ................... 59

10.1.2 Unreviewed Safety Question Process . . . . . . . . . . . . . 59

10.2 Worker Safety . . . . . . . . . . . . . . . . . . . . . . 61

10.2.1. Radiological Screening .................. 62

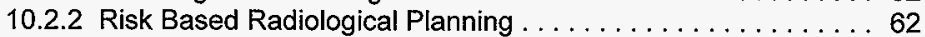

10.3 Post-Deactivation Safety Documentation . . . . . . . . . . . . . 64

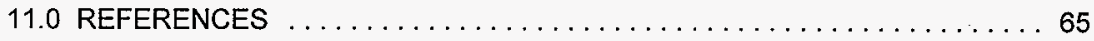

\section{APPENDICES}

APPENDIX A - GLOSSARY ....................... A -1

APPENDIX B - WBS COST ESTIMATE WORKSHEETS ........... B - 1

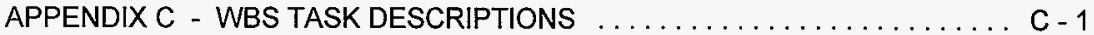

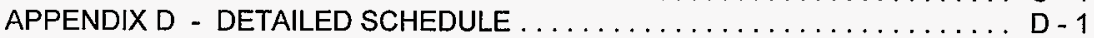

APPENDIX E - INTERIM ENDPOINT SPECIFICATION DOCUMENT . . . . . . E - 1

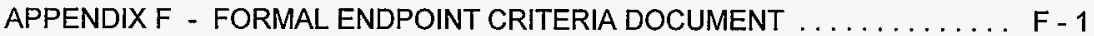

APPENDIX G - SURVEILLANCE AND MAINTENANCE PLAN ..........G -1 
HNF-2230 Rev. 0

\section{TABLES}

Table 5-1. WBS Summary - Phase | Tasks. . . . . . . . . . . . . . 24

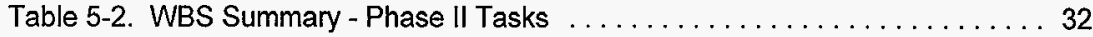

Table 8-1. QA Document Changes ...................... 41

Table 9-1. Summary Closure Status for 340 Complex .............. 48

FIGURES

Figure 1-1. Hanford Complex - Location 300 Area. . . . . . . . . . . . 2

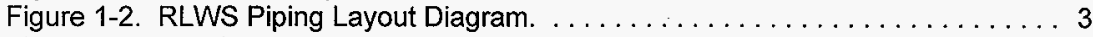

Figure 1-3. 340 Complex Plan View ....................... 11

Figure 1-4. Photos of Specific 340 Facilities . . . . . . . . . . . . . . . 12

Figure 4-1. 340 Complex Transition Management Structure . . . . . . . . . . 20

Figure 6-1. Baseline Schedule Summary. . . . . . . . . . . . . . . . 36

Figure 9-1. 340 Complex Decision Path. . . . . . . . . . . . . . . . . 44

Figure 10-1. USQ Screening and Hazard Assessment Planning. . . . . . . . . 60 
HNF-2230 Rev. 0

\section{ABBREVIATIONS, ACRONYMS AND INITIALISMS}

(Page 1 of 3 )

AGS

AJHA

ALARA

ALARACT

AMW

AOP

$\mathrm{BHI}$

BOE

BWHC

CAP

CERCLA

CFR

$\mathrm{cm}$

CSER

CVI

CX

D\&D

Decon

DOE

DOE-HQ

DOE-RL

$\mathrm{DOH}$

DST

ECN

ECO

Ecology

EM

EM-30

EM-40

EM-60

EPA

EPC

ERC

ESA

ETF

FASTER

FDH

FEMP

FHA

$\mathrm{ft}$

FY
Above ground storage

Automated job hazard analysis

As low as reasonably achievable

As low as reasonable achievable control technology

Alara management worksheet

Air operating permit

Bechtel Hanford, Inc.

Basis of estimate

Babcock \& Wilcox Hanford Company

Cost account plans

Comprehensive Environmental Response, Compensation, and

Liability Act

Code of Federal Regulations

centimeter

Criticality safety evaluation report

Certified vendor information

Categorical exclusion (NEPA)

Decontamination and decommissioning

Decontaminate or decontamination

U.S. Department of Energy

U.S. Department of Energy Headquarters

U.S. Department of Energy, Richland Operations Office

Washington State Department of Health

Double-shell tanks

Engineering Change Notice

Environmental compliance officer

Washington State Department of Ecology

Environmental Management

Office of Waste Management

Office of Environmental Restoration

Office of Nuclear Material and Facility Stabilization

U.S. Environmental Protection Agency

Endpoint criteria

Environmental remediation contractor

Endangered Species Act

Effluent treatment facility

Facility stabilization and environmental restoration

Fluor Daniel Hanford, Inc.

Facility effluent monitoring plan

Fire hazard analysis

foot or feet

Fiscal year 
HNF-2230 Rev. 0

\section{ABBREVIATIONS, ACRONYMS AND INITIALISMS}

(Page 2 of 3 )

G\&A

GFS

gal

h, hr

HCRL

HEPA

HP

HPT

HVAC

IEPC

in.

INEEL

ISB

JCO

$\mathrm{K} 1$

$\mathrm{K} 2$

$\mathrm{K} 3$

$\mathrm{kL}$

LDR

LEF

LLW

LMHC

$\mathrm{m}$

MCM

MOA

MPR

MYWP

NEPA

NESHAPS

NHPA

NOC

O\&M

OU

PHMC

PMP

PNNL

POTW

PRC

PS

QAPP

RCRA
General and administrative (overhead cost adder) Government furnished services (overhead cost adder) gallon(s)

hour(s)

Hanford cultural resources laboratory

High-efficiency particulate air

Health physics

Health physics technician

Heating, ventilating, and air conditioning

Interim endpoint criteria

inch(es)

Idaho National Engineering and Environmental Laboratory

Interim safety basis

Justification for continued operations

340 Complex tank vent exhaust system

340-B ventilation stack exhaust system

340 'Building stack exhaust system

kiloliter(s)

Land disposal restrictions

Liquid effluent facilities

Low-level waste

Lockheed Martin Hanford Corporation

meter(s)

Minimum critical mass

Memorandum of agreement

Material procurement rate (overhead cost adder)

Multi-year work plan

National Environmental Policy Act

National Emissions Standards for Hazardous Air Pollutants

National Historical Preservation Act

Notice of construction

Operation and maintenance

Operable unit (CERCLA)

Project Hanford Management Contractor

Project management plan

Pacific Northwest National Laboratory

publicly owned treatment work (municipal wastewater plant)

Plant review committee

Process sewer

Quality assurance program (or project) plan

Resource Conservation and Recovery Act 
HNF-2230 Rev. 0

\section{ABBREVIATIONS, ACRONYMS AND INITIALISMS}

(Page 3 of 3 )

$\mathrm{RL}$

RLW

RLWS

RMW

RPS

RWP

S\&M

SCW

SEPA

SHONKA

S/RID

SSC

SWCX

TBD

TEDF

TIM

TOP

Tri-Party Agreement

TSCA

TSD

USQ

USQE

WAC

WBS

WHC

WMH

$y, y r$
U.S. Department of Energy, Richland Operations Office

Radioactive liquid waste

Radioactive liquid waste system

Radioactive mixed waste

Retention process sewer

Radiation work permit (or procedure)

Surveillance and maintenance

Special case waste

State Environmental Policy Act

Surface contamination monitor survey information management system manufacturer

Standards/requirements identification document

Structures, systems and components

Site-wide categorical exclusion

To be determined

Treated effluent disposal facility

Training implementation matrix

Turnover package

Hanford Federal Facility Agreement and Consent Order

Toxic Substances Control Act

Treatment, storage, and disposal (facility)

Unreviewed safety question

Unresolved safety question evaluators

Washington Administrative Code

Work breakdown structure

Westinghouse Hanford Company

Waste Management Federal Services of Hanford, Inc.

year(s) 
HNF-2230 Rev. 0

\section{ACKNOWLEDGMENTS}

The authors would like to acknowledge the contributions of many individuals who have helped provide text and/or information, or have otherwise supported the preparation of this PMP. Our apologies to anyone whom we may have inadvertently overlooked.

L. D. Berneski (WMH)

T. F. Cherney (WMH)

M. W Clayton (WMH)

J. W. Deline (WMH)

J. I. Feaster (WMH)

D. L. Halgren (WMH)

K. Kover $(\mathrm{WMH})$

S. S. Lowe (WMH)

S. N. Luke (WMH)

A. G. Miskho (FDH)

L. T. Pedersen, Jr. (LMHC)

W. A. Peiffer (BWHC)

J. K. Perry (WMH)

D. B. Powell, Jr. (WMH)

D. E. Roohr (WMH)

J. L. Ryan (BWHC)

D. R. Schell (WMH)

L. D. Stefanski (BWHC)

R. W. Szelmeczka (WMH)

P. L. White (WMH)
Facility info, safety, work process

Facility radiological survey info

Safety

Electronic photos of 340 Facility

Historical document searches

Strategy and review

TSD processing costs

LR56 usage requirements/costs and review

Regulatory closure basis and approach

Regulatory review

Remote camera inspection estimates

Example PMP boilerplate

Air emission regulatory review

Estimated cost for RLWS excavation

Facility expertise (current and past operations)

Endpoint criteria; and related, rough WBS

Quality assurance process

Endpoint criteria

Regulatory strategy and review

Davis-Bacon issues, work package process

R.B. Barmettlor (WMH), K.J. Svoboda (FDH) and E.M. Bowers (RL), among others, also assisted with their suggestions and/or their approvals of significant improvements in deactivation strategy. 
HNF-2230 Rev. 0

This page intentionally without substantive content. 
HNF-2230 Rev. 0

\subsection{OVERVIEW}

\subsection{Introduction}

The Project Management Plan (PMP) for the 340 Complex transition project sets forth the plans, cost and schedule baselines, and organization and control systems for managing the deactivation and transition activities. The project includes the deactivation of the Radioactive Liquid Waste System (RLWS) piping, RLWS support facilities, and ancillary buildings within the 340 Complex. It also includes the 307 Basins following the termination of any Retention Process Sewer (RPS) system mission. Upon completion of deactivation and transition activities, the residual 340 Complex will be turned over to the Environmental Restoration Contractor (ERC) Office of Environmental Restoration (EM-40) for surveillance and maintenance, as well as final disposition. The RPS piping itself may continue to provide a non-radioactive process sewer (PS) function after this turnover. A map of the Hanford Site is provided, with the location of the 340 Complex shown, in Figure 1-1.

The RLWS portion of the 340 Complex is classified as a non-reactor Category 3 nuclear facility, while the RPS and 307 Basins are classified as nonnuclear, less than Category 3. The complex is also classified as an Isolated Facility in accordance with HNF-PRO-334 (FDH 1997e). This designation identifies facilities that contain or could contain more than 3 percent of a minimum critical mass (MCM) of fissionable material, but no more than one-third of an MCM.

The 340 Complex is managed as a less-than-90-day waste accumulation area. Radioactively contaminated liquid wastes, some of which are contaminated with hazardous wastes, are directed to the 340 Complex via the RLWS and RPS systems. Liquid wastes are received by one of four routes:

- Direct from the RLWS, the primary path (Figure 1-2),

- Via tanker trucks or drums,

- Via transfers from the 307 basins, or

- Through diversions from the RPS system.

During normal operations liquid wastes are shipped to the 204-AR waste receiving station in the 200 Area by rail tanker car.

The 340 Complex transition tasks will be accomplished by implementing a two-phased approach. Phase I activities involve terminating the RLWS system, isolating the RPS from the RLWS, decontaminating and stabilizing selected RLWS systems and spaces, and shipping wastes associated with deactivation activities. Phase II initiates the interim monitoring period, and ends with final deactivation of all 340 Complex systems and spaces. 
HNF-2230 Rev. 0

Figure 1-1. Hanford Complex - Location 300 Area.

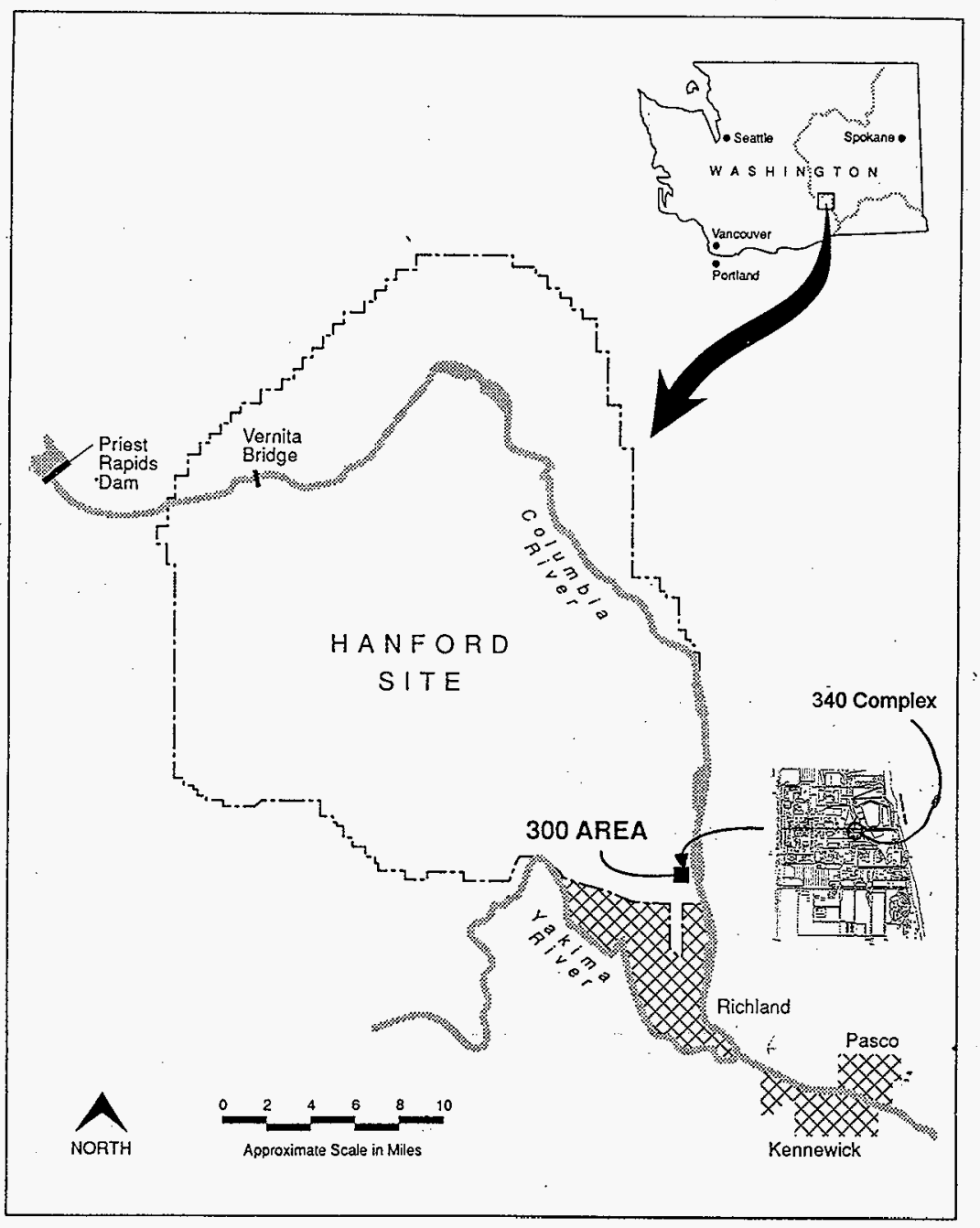


HNF-2230 Rev. 0

Figure 1-2. RLWS Piping Layout Diagram.

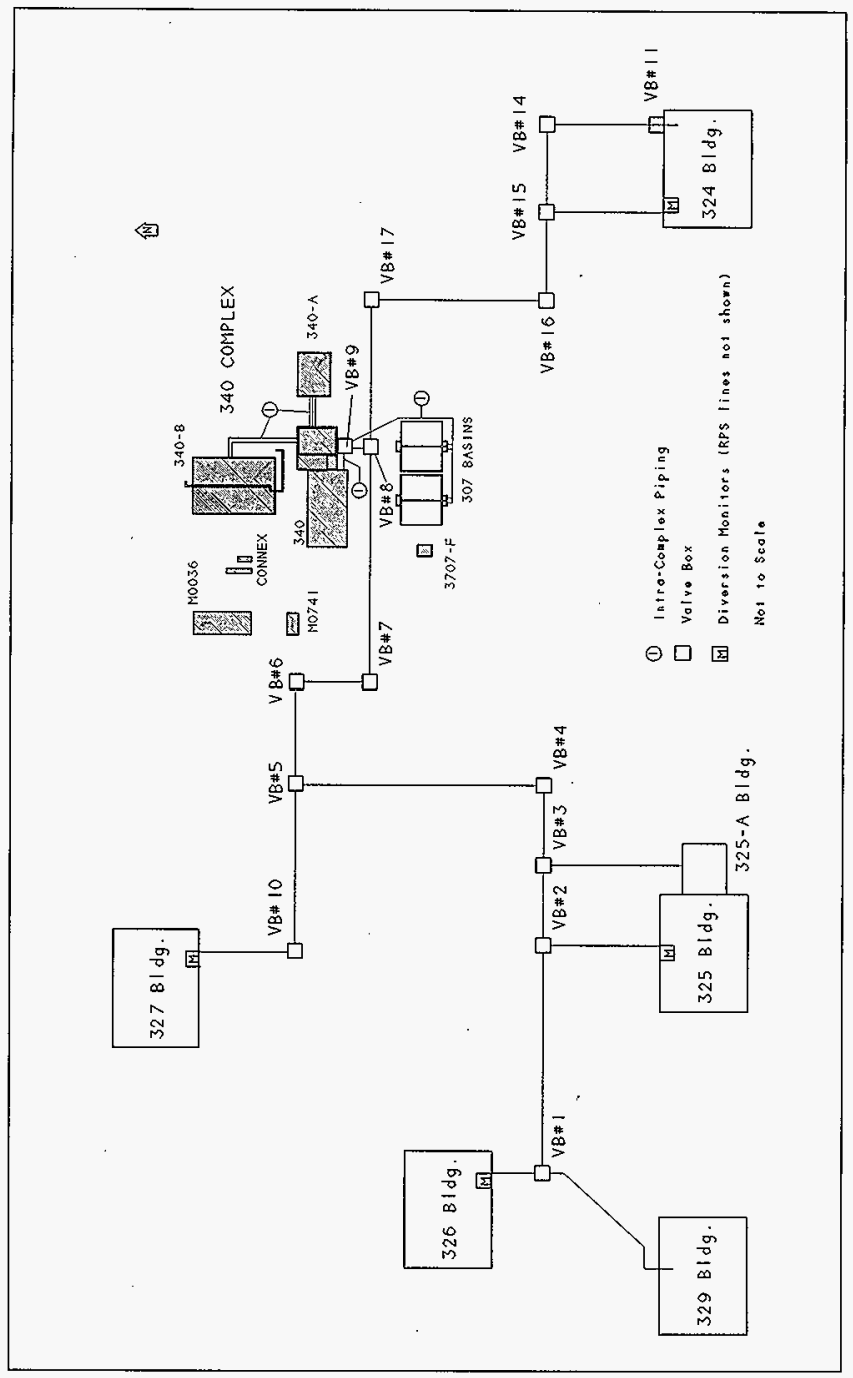




\subsection{Purpose}

The purpose of the 340 Complex transition project is to establish a passive, safe and environmentally secure configuration for the 340 Complex This will enable turnover to the ERC of a complex that requires minimal out-year surveillance and maintenance (S\&M) and preserves that configuration for a 10-yr horizon. The 10-yr horizon is used to predict future maintenance requirements and represents the typical time duration expended to define, authorize, and initiate the follow-up decontamination and decommissioning (D\&D) activities.

Deactivation and transition tasks remove, reduce, and/or stabilize the radioactive and hazardous wastes within the complex. Completing these activities reduces hazards to workers, the public, and environment, and allows for a reduced level of surveillance while waiting final disposition. When fully deactivated, the 340 Complex will be unoccupied, empty, and locked. There will be no active systems or utilities in the buildings with the exception of surveillance lighting and any necessary monitoring instrumentation. Externally there may remain an active fire hydrant and several manholes associated with the PS lines passing under the site.

\subsection{Project Management Plan Overview}

This Project Management Plan (PMP) has been prepared in accordance with the guidelines provided in U.S. Department of Energy (DOE) Order 430.1A Life Cycle Asset Management (DOE 1996); the Hanford Federal Facility Agreement and Consent Order (Tri-Party Agreement) (Ecology et al. 1989); Amendment Six, Section 8.0, "Facility Decommissioning Process" (Ecology et al. 1996); and applicable experience from nuclear facility deactivation projects, both commercial and DOE. The intent of this PMP is to describe how the 340 Complex transition project will be managed and to present summary level scope, cost and schedule information.

The PMP is organized into two distinct, but related, parts as described below:

- The main body of the PMP, also defined as a Strategic Management Plan, describes the vision for the 340 Complex transition, including project scope, objectives, and key strategies for accomplishing the transition work. In addition, this section describes the project management approach that will be used throughout the transition phase of 340 Complex decommissioning, including management structure, roles, responsibilities, and organization interfaces. The PMP document will be revised, as needed, as the project progresses and as the detailed supporting documentation, the PMP Appendices, are further refined.

- The PMP supporting appendices provide the detailed documentation for application and implementation of the PMP strategies. The supporting appendices also provide the detailed schedule and detailed cost data. The supporting appendices will be used to provide guidance to project staff for dayto-day management of the project and will be developed, maintained and 
HNF-2230 Rev. 0

approved by the waste management contractor, Waste Management Federal Services of Hanford, Inc. (WMH). Ultimately included will be the official Endpoint Criteria (EPC) and the Surveillance and Maintenance (S\&M) Plan.

\subsection{Assumptions}

Assumptions needed to complete the baseline planning case, and for subsequent planning activities throughout the PMP implementation period, are consolidated here. Section 1.5 Uncertainties, which follows, discusses some of the potential impacts if the assumptions do not hold.

1.4.1 There has been and will be no formal shutdown decision from the DOE Headquarters (DOE-HQ) relevant to the 340 Complex deactivation.

1.4.2 None of the 340 Complex tanks or wastes are, or will be, designated as Toxic Substances Control Act (TSCA) regulated.

1.4.3 Any tasks tentatively scheduled for completion by the end of FY98, even if mentioned or outlined in this PMP, will of necessity be funded, designed, planned, and implemented, independent of management under this PMP.

1.4.4 Voluntary RLWS transfers to the 340 Complex will be terminated by September 30,1998 . Until the RPS system is fully decoupled from the RLWS, some or all of the existing waste diversion, storage and transfer apparatus may be retained in a state of operational reserve. Once decoupling is complete, all possibilities for waste transfer to the 340 Complex via the RLWS will have been eliminated.

1.4.5 Whenever clear mandates cannot be determined directly from environmental regulations, a path that involves low cost and minimal employee and public risk will be proposed as a planning case, subject to future formal determinations.

1.4.6 All inactive waste sites are excluded from the scope of this PMP.

1.4.7 The task of bypassing the vault tanks for transfers from the basins to $340-\mathrm{B}$ (as long-term RPS contingency routing) can be accomplished with plant operating and matrixed craft forces.

1.4.8 The waste transport path by rail, i.e., by $75.7-\mathrm{kL}(20,000-\mathrm{gal})$ tanker with DynCorp Tri-Cities Services, Inc. crew and U.S. Department of Energy, Richland Operations Office (DOE-RL or RL) locomotive, will cease operations as of September 30, 1998 (DynCorp 1998).

1.4.9 After terminal clean out activities are complete, a safety basis re-evaluation will determine that the hazard classification for the 340 Complex will be changed 
from non-reactor nuclear Hazard Category 3, to Radiological. The 340 Complex should also lose its present classification as an Isolated Facility (FDH 1997e and WHC 1996a). The 307 Basins/RPS system is nonnuclear, below Category 3, (Berneski 1995). At the end of Phase II, it should be re-classifiable as Industrial.

1.4.10 Funding adequate to cover the budgetary needs estimated by this PMP will be detailed and provided in time to meet the outlined schedule.

1.4.11 Sufficient treatment and disposal capacity to manage hazardous debris and radioactive wastes generated from deactivation, and closure activities will be available, either on-site or within the local community.

1.4.12 The vault tanks will require removal prior to transition of the complex to the ERC because of the likely inability to effectively treat them in place. Their removal should also facilitate closure of the vault. Attempts will first be made to clean the 340-A tanks in place. Removal of any tanks will be scheduled as Phase II activities.

1.4.13 Scabbling the surface of the Vault floor, sump and lower $0.6 \mathrm{~m} \mathrm{(2ft)}$ of walls, wherever the coating has not protected the concrete), to a depth of no more than $0.6 \mathrm{~m}(0.25 \mathrm{in}$.) will result in a clean debris surface (also Phase II).

1.4.14 The National Historic Preservation Act (NHPA) related assessments and reviews will not impact deactivation.

1.4.15 The endpoint criteria (EPC) ultimately, i.e., under Phase II, negotiated with the ERC will not deviate significantly from the EPC derived by the Babcock and Wilcox Hanford Company (BWHC) Facility Stabilization and Environmental Restoration (FASTER) team for this PMP.

1.4.16 Phase I clean out and deactivation activities related to work in the Vault will likely require filing a notice of construction (NOC) associated with potential emissions from the 340 major stack filter system, which is subject to continuous emission measurement requirements of $40 \mathrm{CFR} 61.93$. After the removal or containment of residual contamination during Phase $\mathrm{I}$, it will be downgraded to a minor stack with its air emissions unit subject to periodic confirmatory measurement requirements ( 40 CFR 61). It is further assumed, under the baseline planning case, that the filter system can be shut down near the end of Phase I.

\subsection{Uncertainties}

The previous assumptions reveal that a number of uncertainties exist. The consequences of inaccurate assumptions or choosing other alternatives are discussed 
in this section, grouped under related topic headings dealing with regulatory, budgetary, technological, and scheduling issues.

\subsubsection{Parallel Negotiations with Regulators}

This PMP outlines a deactivation program grounded in regulatory experience and moderated by an awareness of recent trends at Hanford, as discussed in Section 9.0. Regulatory statutes usually require added interpretation for proper application under specific circumstances. In addition, there is a need to reconcile technological, budgetary, and safety constraints against the goal of optimum environmental protection and restoration. It would not be possible to settle on a final closure strategy approved by all involved parties prior to issuing this PMP. A number of deliberate reappraisal steps are, therefore, included in this PMP. These reappraisal steps consist of activities, such as the preparation of pre-task regulatory permits and notifications; assessments of residual hazards following preliminary cleanup steps; regulatory status evaluations; and the official endpoint negotiations ultimately needed before turnover to the ERC.

The possible need to remove the large tanks and buried piping associated with the RLWS system has a major influence on cost. While this PMP depicts tank removal as the likely precondition for meeting Resource Conservation and Recovery Act (RCRA) dangerous waste closure requirements, it proposes, based upon economic and safety considerations, leaving the RLWS piping for eventual remediation along with all similar buried equipment. It is believed that sufficient documentation exists to establish the integrity of the double-walled pipe systems. However, the decision to leave the tanks or to retrieve the piping await subsequent negotiations and evaluations. It is recognized that the Environmental Protection Agency (EPA)-Richland Office has Comprehensive Environmental Response, Compensation and Liability Act (CERCLA) authority and will be involved in decisions regarding possible remediation undertaken as part of any operable unit. A pre-conceptual cost estimate for the removal of the RLWS piping is around $\$ 3.3$ million, which does not include final disposal of retrieved pipe, nor the likelihood of encountering soil contamination.

It was recently determined that waste in the 340-A tanks is not regulated under the authority of the TSCA. Should special TSCA provisions (40 CFR 761) arise, plans for cleaning out, removing and/or disposing any equipment and waste within the 340 Complex could be impeded.

An additional deactivation concern with regulatory implications is the fate of the 340 major stack which ventilates the Vault, all 340 tanks, and the RLWS piping. The tank vent exhaust system, K1, has undergone recent evaluations by the Washington State Department of Health (DOH) in connection with NOCs developed for preliminary 340-A sludge removal activities. While there may be merit in retaining this system for use during removal of the Vault tanks, uncertainties in the both timing of such work and in continued DOH approval for use led to the proposal in this PMP for removal of the K1 system following Phase I clean out tasks. 


\subsubsection{Budgetary Considerations}

The September 1998 termination of waste receipts at the 340 Complex was prompted by management's determination that available radioactive liquid waste (RLW) disposal electives, coupled with limited generator missions, made it undesirable to correct operational and regulatory deficiencies at the 340 Complex. Early funding to implement this decision went to generator upgrades to replace the RLW services rendered by the 340 Complex. Subsequent tight budgets and higher site priorities have led other 340 shutdown activities to fall below the line. Aside from funding the preparation of this PMP, all anticipated FY98 budget needs have been pushed to FY99.

Any further funding delays or shortfalls will require re-scheduling and revision the scope of some of the activities, which will in turn, impact subsequent projections or plans based on this PMP. The two-phase approach to the 340 Complex deactivation defers many of the big ticket items for the post-2001 time frame. While this deferral rests on a logical cleanup progression, it carries the added benefit of allowing more time for further studies and agreements that should firm up, justify and help secure out-year budgets. This plan does not attempt to project the post-Phase I operation and maintenance (O\&M) costs related to continuing RPS operations. These costs will decrease over current 340 O\&M levels, but it is difficult to anticipate how partial headcount reductions may be handled which would play a key part in determining the amount of this reduction.

\subsubsection{Technical Methodology}

Examples of areas in the PMP where other techniques or approaches could impact costs are:

- Planned camera surveys of the piping and tanks,

- Number of samples and analyses of concern for establishing decontamination (decon) efficiency,

- Amount and type of cleanup solutions and means for their transport to the 200 Area,

- Possible need for robotic sludge removal devices, an example of which costs $\$ 65,000$, or solids might be left for later removal along with tank, and

- Optional, non-conventional radiation survey instrumentation, i.e., a surface contamination monitor survey information system designed by SHONKA used at Idaho National Engineering and Environmental Laboratory (INEEL).

The PMP allows for detailed work package preparation that will afford an opportunity to refine methodology. The reassessments previously mentioned could eliminate some needs or result in new needs. This PMP is not a comprehensive engineering study; instead, it responds to a request for budgetary detail, which required the development 


\section{HNF-2230 Rev. 0}

of specific task packages. The actual decommissioning path could vary from the assumed baseline planning case.

\subsubsection{Scheduling Considerations}

Although rail service is to be terminated on September 30,1998 , there are indications that this date could be as early as July 1998 in order to disposition rolling stock in advance. The termination date could be extended several months, or even years, beyond September 1998 to accommodate potential usage by off-site waste generators sending large objects to the Hanford Site. Early termination of the rail service complicates the final months of the 340 Complex shutdown planning, while an extension could save money by deferring or even eliminating some load-out modifications, reducing the number of shipments through use of the higher volume rail tanker, and reducing crew exposure with spacer cars. The longer the time to clear up the uncertainty, the smaller will be the cost savings.

Another key timing uncertainty is how long the RPS system will need to operate. Indications from Pacific Northwest National Laboratory (PNNL) is that its 325 Laboratory has a mission well into the next century; and, thus, has a concomitant need for the services of the 340 Complex. That need would disappear, however, if high risk radiological activities are consolidated to the 200 Area plateau per the Hanford Strategic Plan (DOE-RL 1996a). Until an answer emerges on the RPS mission, there can be no firm Phase II out-year schedules. However, it is realized that not all elements included under Phase II are tied directly to the end of the RPS mission, as Figure 6-1 depicts; therefore, subject to funding, some tasks could proceed independently.

\subsection{Complex Description}

The following provides a brief summary of the buildings within the 340 Complex and associated liquid waste distribution piping systems. Several other documents, such as the 340 Waste Handling Facility Interim Safety Basis (ISB) and the 340 Waste Handling Facility Deactivation Plan (WHC 1996c and WMH 1996), provide more detailed information. A plan view of the 340 Complex is provided in Figure 1-3; while Figure 1-4 presents selected pictorial views.

The 340 Complex consists of the following:

- 340 Building/annex - includes a control room, decontamination area, mechanical equipment room, change and rest rooms, truck lock area, and an operator's office. The process water, vacuum, and compressed dry air subsystems are contained within these structures.

- Vault - below grade concrete, contains two 57-kL (15,000-gal) tanks for primary RLWS storage. Includes adjacent HEPA filter ventilation system.

- 340-A Building - houses six 30-kL (8,000-gal) above ground tanks for auxiliary 
HNF-2230 Rev. 0

RLWS storage; tanks are vented through Vault filter system. Transfers to the 340-A tanks require pumping from the Vault tanks.

- 340-B Building - divided into the East, a station for RLWS load-outs currently via railroad tank cars; and West, which is used for radioactive solid waste storage and for housing ventilation equipment for East.

- 3707-F Building - houses RPS sampling equipment and controls.

- MO-036 - a double-wide trailer inside the 340 Complex fence, that provides offices for engineering, radiation control, and operations personnel.

- MO-741 - health physics technicians' (HPTs') office and survey station consisting of two personnel contamination monitors.

- The RLWS - consists of encased underground piping and ancillary equipment which connects individual PNNL and BWHC buildings to the Vault tanks for gravity drained liquid transfers. Figure 1-2 illustrates the layout of the RLWS system, from the generator facilities to the 340 Complex.

- The RPS system - a recently relined, single wall piping system, which combined with the 307 Basins, is designed to segregate process effluents potentially contaminated with radionuclides at levels not acceptable for treatment at the 300 Area Treated Effluent Disposal Facility (TEDF). Laboratories on the RPS circuit include $324,325,326,327$, and 329 .

- 307 Basins - four lined concrete reservoirs, each with actual size of 190-kL $(50,000-\mathrm{gal})$ and a routine capacity of $95-\mathrm{kL}(25,000$-gal). 
Figure 1-3. 340 Complex Plan View (minus mobile offices and Conex/Sealand containers).

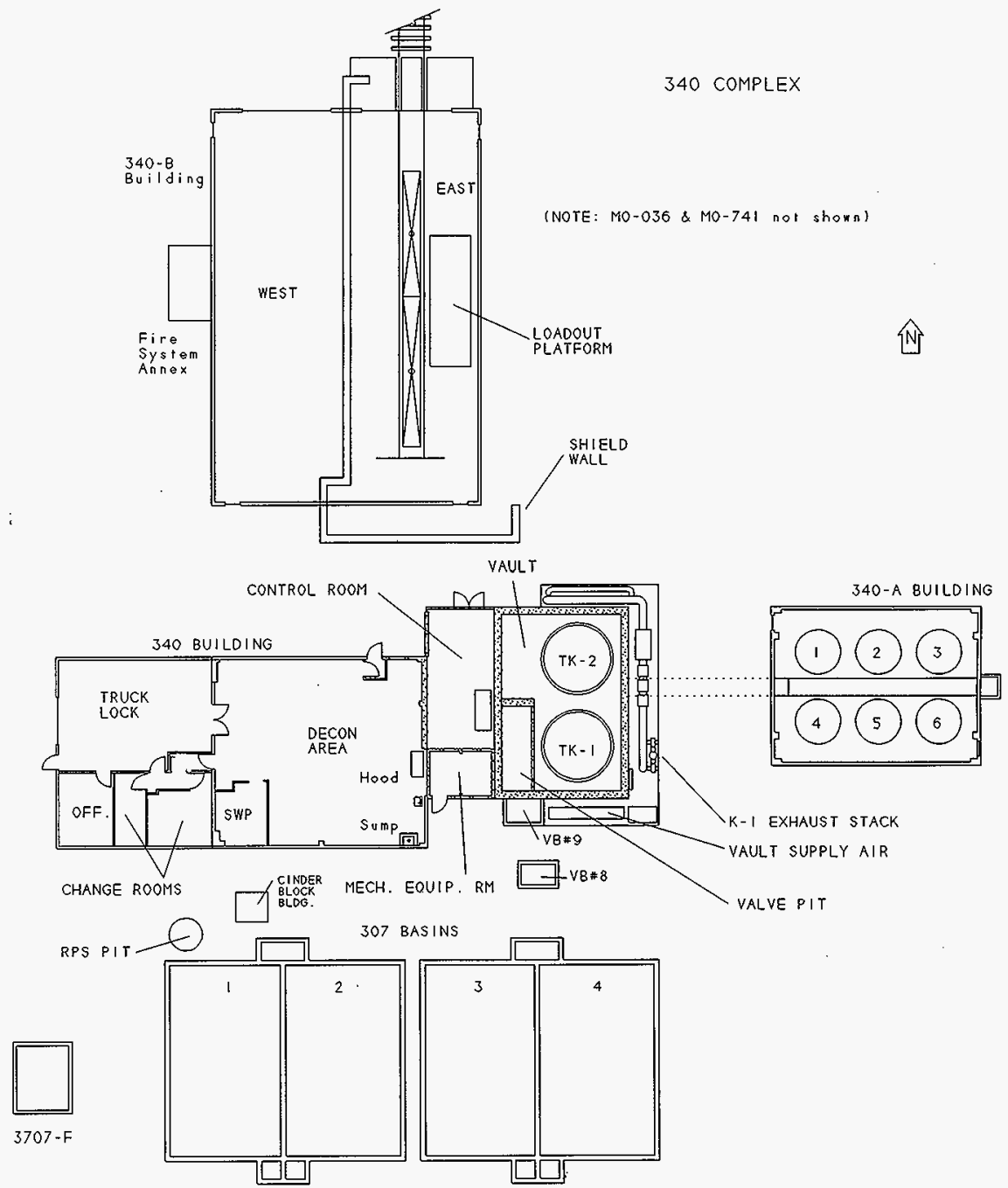


Figure 1-4. Photos of Specific 340 Facilities (1 of 2).
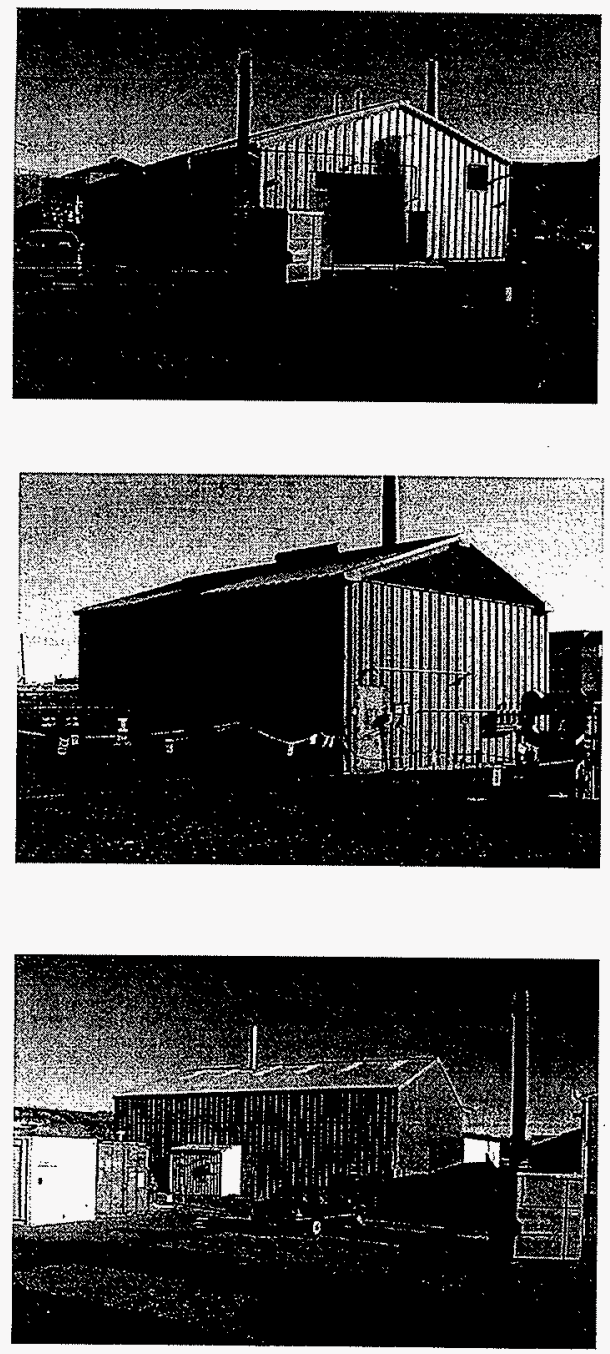

(a) 340 Building, showing Truck Lock and east entrance.
(b) 340-A Building, northwest corner, showing partial vault ventilation system

(c) 340-B Building, west side showing Fire System Annex and material storage connex/sea-land containers. 
HNF-2230 Rev. 0

Figure 1-4. Photos of Specific 340 Facilities (2 of 2).

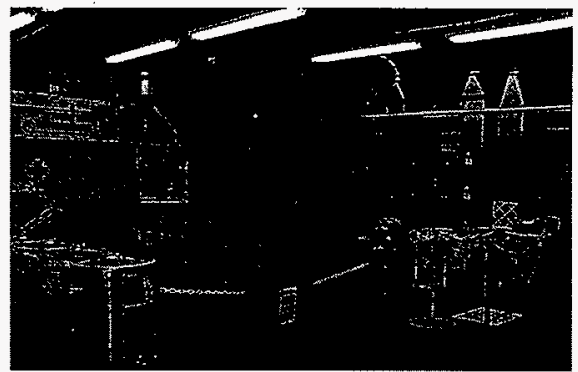

(d) 340 Bldg, Decon Area, showing Hood and K3 Vent. System prefilters.

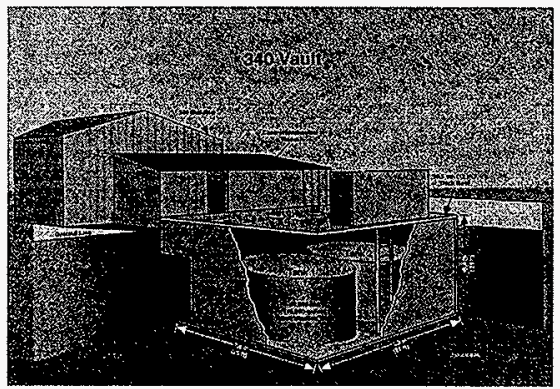

(e) 340 Vault cut-away showing underground tanks.

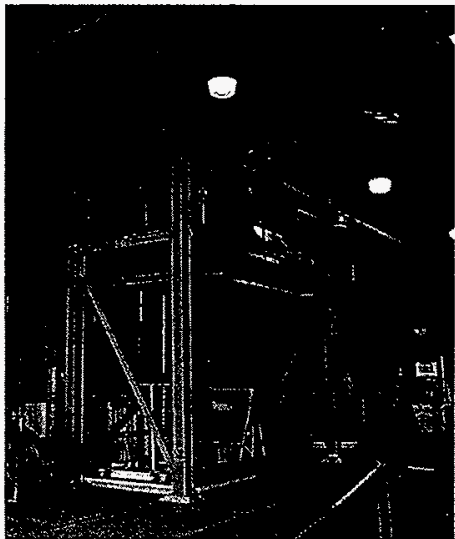

(f) 340-B East Bldg., Load-out platform. 
HNF-2230 Rev. 0

This page intentionally without substantive content. 


\subsection{PROJECT OBJECTIVES}

WMH has been directed by Fluor Daniel Hanford, Inc. (FDH) and DOE -RL Office of Waste Management (EM-30) to pursue the most cost effective means for terminating operations and cleaning out the RLWS portion of the 340 Complex according to DOE and regulatory guidelines, while at the same time keeping the RPS system operational. A two-phase approach has been formulated which will eliminate the added costs related to either an interim transition to Office of Nuclear Materials and Facility Stabilization (EM-60), or a piecemeal and largely premature turnover to EM-40.

In Phase I, the 340 Complex's core facilities associated with the RLWS would be decoupled from the RPS, the inventory removed, and radiological control areas minimized. Although some areas of this core would be deactivated to a point typically required for turnover to the ERC, WMH will retain control of the 340 Complex until the mission for all its functions ceases. The remaining facilities would either be linked to daily RPS operation or held in standby should they be needed to support the RPS.

Phase II begins with the interim monitoring of those portions of the Complex that were either deactivated or placed in standby under Phase I. Phase II is also when major closure activities, such as the removal of the Vault tanks, would occur. Phase II eventually involves the ultimate shutdown of the entire 340 Complex, and its final deactivation and turnover to the ERC. This would occur when there is no longer a need for the RPS. Ongoing RPS operations, during either Phase, are beyond the province of this PMP.

It should be noted that the above objectives are being met with an approach differing from that outlined in the last revision of the 340 Deactivation Plan, HNF-SD-LEF-SSP001, Rev. 1 (WMH 1996). That Plan envisioned the partial turnover to the ERC of the core RLWS facilities after an approximate 3-yr deactivation period, yet did not address the eventual RPS disposition. It also proposed constructing a new load-out facility for the RPS system, versus the current concept of modifying 340-B East, an option opened up by the two-phase approach. Under Phase I of this PMP most of the clean out goals of the Plan will be accomplished, with the tank removal/disposal tasks being scheduled under Phase II. This strategy accommodates the fact that the 340 Complex is not currently included on the ERC's list of pending transitions, as well as the need to finalize the RCRA/dangerous waste closure strategy, as a basis for out-year budgeting.

As previously outlined, a key and complicating aspect is the need to sever ties between the RPS and RLWS systems, due to the former's continuing mission to protect the 300 Area TEDF from potential radionuclide releases. These tasks include things such as hardwiring the upstream, in-line radiation monitor alarm signals to the 307 Basin control system; modifying software to use 307 inlet manifolds valving to send any related RPS diverts to a dedicated basin; and providing a path between said basin and the 340-B East load-out facility. Even though these tasks are described in this PMP, because of the need to expedite many of these activities, they may be pursued independently of this PMP. 
HNF-2230 Rev. 0

This page intentionally without substantive content. 


\subsection{PROJECT SCOPE}

As described in Section 1.6, the 340 Complex includes the 340, 340-A, 340-B, and 3707-F buildings, the Vault tanks, the 307 Basins, and the RPS/RLWS piping networks. This PMP follows these components through their near-term categorization as either operational, in standby, or deactivated; up to their ultimate turnover to the ERC. It outlines the tasks needed to accomplish this, as well as estimating the needed time, manpower and material resources, and the associated costs. Due to the ambiguous nature of Phase II activities, a lessor degree of detail accompanies their presentation. It is anticipated that the scope of Phase II activities will change as the result of both ongoing negotiations with the regulators, and finalization of EPC and S\&M Plan that the ERC officially will accept. In that regard, this PMP is seen as a living document that primarily establishes the basic transition management structure and overall strategy.

The RPS piping, 307 Basins, 340 truck lock, 340-B (East and West), 3707-F, and MO036 \& MO-741 trailers will be utilized in support of continuing RPS operation.

Laboratories that will be retained on the RPS circuit include $324,325,326,327$, and 329. Flows from some of these buildings should be eliminated as they are deactivated, with 325 being the ultimate contributor. The possibility of it internally managing its own RPS has been ruled out (Apley 1996 and WHC 1996f). The costs for RPS operations are outside the scope of this PMP.

The 340 Decon Area, control room, and mechanical equipment room will be cleaned, and/or secured, and placed in standby for potential future use. Although explained in greater detail in Section 9.1, after removal of dangerous waste residues, the capped RLWS piping will be transferred to the ERC for probable removal during cleanup of the CERCLA operable unit it resides within. It is recognized that the EPA-Richland Office has CERCLA authority and will be involved in any decisions regarding remediation undertaken as part of the operable unit. The $300-F F-2$ operable unit proposed plan is due to the regulators in July 1999, and it should include the scope of all 340 Complex closure activities that may be deferred to the ERC. Currently, efforts are underway to coordinate with the generators on the possibility of flushing building headers and RLWS piping out to the first valve box. Such actions, if taken, would still be supplemented with the pressure washing proposed in Phase I.

Similarly, tanks in both the 340-A Building and Vault will, at a minimum, have their waste inventories removed and be placed in a secure state subject to monitoring. The need for removing some or all the tanks and sending them (and other contaminated debris) to a treatment, storage and disposal (TSD) facility for eventual disposal, is also addressed. In such cases, the extent of prior inventory removal might be modified, since the TSD unit can accommodate tank heels. The 340-A Building and Vault themselves will also receive appropriate decontamination, e.g., the concrete surfaces in those structures that have been exposed to liquid waste may require scabbling. The K1 ventilation system will likely be removed and disposed after completing Phase I Vault tasks. 
HNF-2230 Rev. 0

This page intentionally without substantive content. 


\subsection{PROJECT ORGANIZATION}

\subsection{Project Management}

The Manager of 300 Area Liquid Effluent Facilities (LEF), WMH, has the overall management and decision-making authority for the 340 Complex Deactivation Task and the responsibility to complete the deactivation work within the approved cost and schedule baseline. The 340 Complex Project Manager has the responsibility for managing the day-to-day activities required to complete the task work and reports to the Manager of Process Engineering. The 340 Complex Project Manager is also responsible for subcontractor interface, negotiating end points, stakeholder involvement, and communications. The WMH management structure for the 340 Complex Deactivation Task consists of the management structure shown in Figure 4-1.

\subsection{Responsibilities}

Responsibilities of the WMH organization supporting the 340 Complex Deactivation Task are identified below:

\subsubsection{Liquid Effluent, Process Engineering}

- Provide project management and oversight for transition activities,

- Document activities in Project Log and maintain turnover package,

- Coordinate and direct implementation contracted tasks, and

- Maintain facility authorization safety basis.

\subsubsection{Liquid Effluent, 340 Waste Handling Facility Operations}

- Operate the 340 Complex as necessary to support transition tasks and

- Provide institutional expertise to assist in task planning details.

\subsubsection{Liquid Effluent, Work Control and Maintenance}

- Provide maintenance support to task activities as necessary,

- Coordinate and facilitate work packages to implement tasks, and

- Identify labor support organizations.

\subsubsection{Liquid Effluent, Facility Safety}

- Confirm approved task activities meet safety requirements, and

- Provide oversight of approved activities. 
HNF-2230 Rev. 0

Figure 4-1. 340 Complex Transition Management Structure.

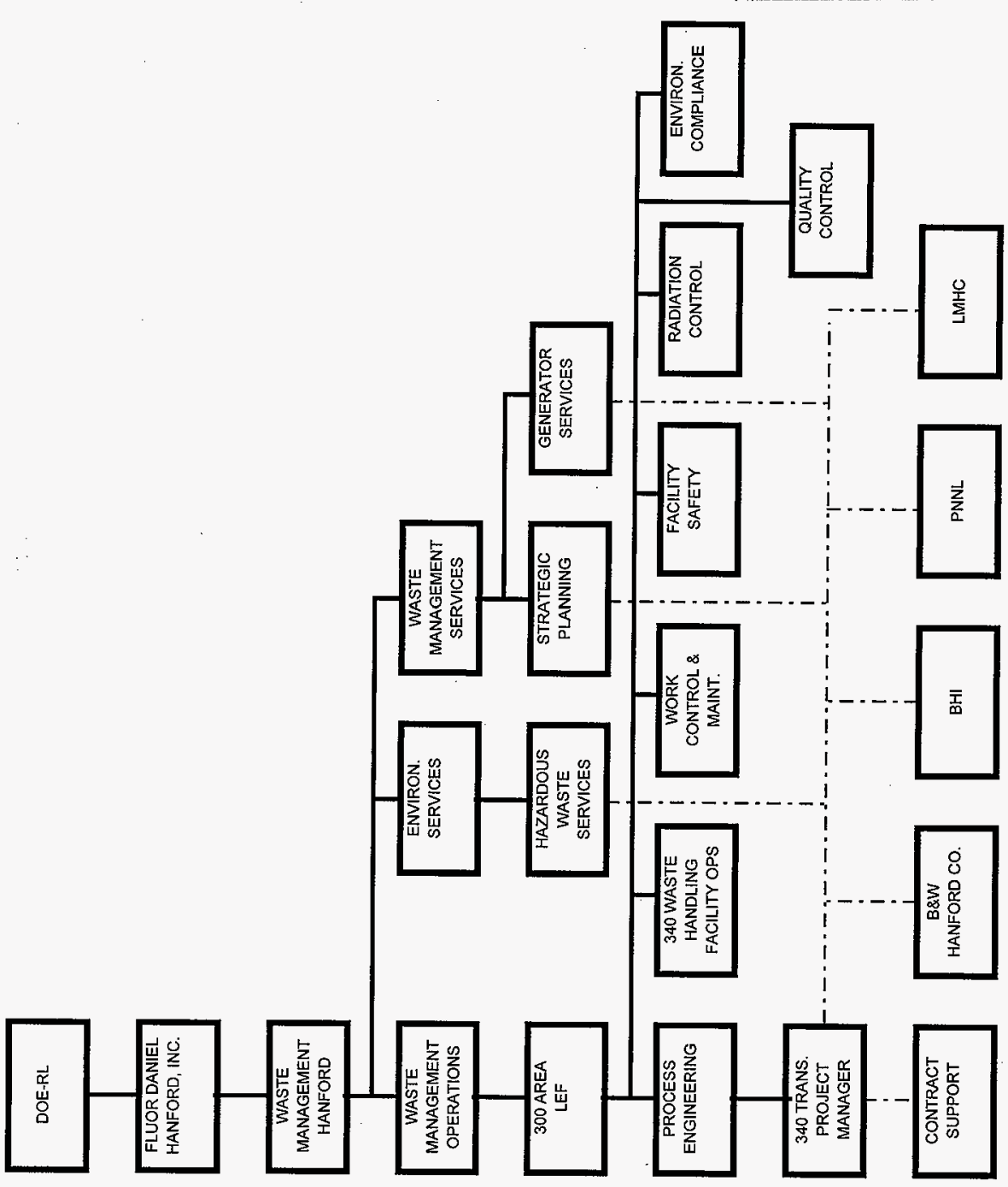




\subsubsection{Liquid Effluent, Radiological Control}

- Provide health physics (HP) oversight for transition activities,

- Provide radiation work permits (RWPs) and radiological control technicians as necessary to support transition activities, and

- Recommend as low as reasonably achievable (ALARA) actions.

\subsubsection{Liquid Effluent, Environmental Compliance}

- Ensure proposed task activities meet applicable environmental regulations, and

- Participate in regulatory negotiations and assist in obtaining necessary permits, NOCs, etc.

\subsubsection{Liquid Effluent, Quality Control}

- Serve as the 300 Area LEF interpretive authority for Quality Assurance (QA) issues and 10 CFR 830.120 , and

- Perform periodic oversight, as requested by Facility Management, to assure the application of the QA Program, refer to Section 8.0, to this project.

\subsubsection{Environmental Services}

- Support LEF Environmental Compliance Officer (ECO) in ensuring that proposed task activities meet applicable environmental regulations, and

- Support LEF-ECO in regulatory negotiations and assist in obtaining necessary permits, NOCs, etc.

\subsubsection{Strategic Planning and Generator Services}

- Obtain, negotiate for necessary budget,

- Assist in obtaining necessary agreements with waste transporter owners, etc., and

- Assist with RLW transfers to Lockheed Martin Hanford Corporation (LMHC). 
HNF-2230 Rev. 0

This page intentionally without substantive content. 
HNF-2230 Rev. 0

\subsection{MANAGEMENT AND CONTROL}

The Management and Control systems to be used for the 340 Complex Transition tasks and activities are contained in the HNF-PRO-518 through 536 series that now replace HNF-CM-2.5, Management Control System (WHC 1998). Transition work scope is organized into a Work Breakdown Structure (WBS), as shown in Table 5-1, for Phase I. The WBS organizes the work into major tasks, which are further broken down into more detailed subtasks. Based on the WBS and the estimate of resources needed, resource-loaded working schedules are developed. Appendix $\mathrm{C}$ provides greater task descriptive detail.

Phase II tasks are identified in Table 5-2, reflecting less detail due to regulatory uncertainties and unknown final RPS termination date. Some of these Phase II tasks may not ultimately be required (e.g., Phase I subtask 3.3 covers Phase II subtask 1 of 5.0 , unless the Decon Area is called back into service as speculated in section 3.0; or subtasks 1 and/or 2 of 10.0 might change if the ERC had use for the office space).

Progress will be formally statused and reported monthly through the Site Management System Report, and will include accomplishments, progress toward milestones, financial status, planned activities, and issues. Periodic task reviews will be conducted by the 340 Complex Project Manager for interested stakeholders.

If it becomes necessary to change the technical, schedules, and/or cost baselines these changes will be managed in accordance with WMH-MD-018 Baseline Change Control and HNF-PRO-585, Cost Estimating (WMH 1998a and FDH 1998). The taskspecific regulatory status evaluations following Phase I clean out efforts, along with the later S\&M Plan and formal endpoint criteria (EPC), will finalize the distinct scope for Phase II. The PMP will need to be revised during that stage in order to define the associated tasks in better detail and generate more legitimate budget and schedule estimates. 
HNF-2230 Rev. 0

Table 5-1. WBS Summary - Phase I Tasks. (Sheet 1 of 7)

\begin{tabular}{|c|c|}
\hline WBS ELEMENTS & DESCRIPTION \\
\hline \multirow[t]{2}{*}{ Task Package 1.0} & DOCUMENTATION \\
\hline & $\begin{array}{l}\text { Task Package } 1.0 \text { provides for the preparation of plans, reports, and documentation required } \\
\text { for the conduct, implementation, and completion of transition work and RCRA closure issues. } \\
\text { The following subtasks included in this Task Package are applicable to Phase I activities. }\end{array}$ \\
\hline Subtask 1.1 & $\begin{array}{l}\text { Unresolved Safety Question (USQ) Screening } \\
\text { Provides for document preparation of USQ process during Phase I deactivation and transition } \\
\text { activities. }\end{array}$ \\
\hline \multirow[t]{2}{*}{ Subtask 1.2} & Administrative Manuals \\
\hline & $\begin{array}{l}\text { Provides for the revision and updating of facility administrative manuals as required due to } \\
\text { changes in structures, systems and components as a result of deactivation activities. }\end{array}$ \\
\hline \multirow[t]{2}{*}{ Subtask 1.3} & Establish Turnover Package File \\
\hline & $\begin{array}{l}\text { Provides for establishing central file for documents and reports generated during and after } \\
\text { completed deactivation activities so that documents required to be turned over to the ERC } \\
\text { can be controlled and maintained. }\end{array}$ \\
\hline \multirow[t]{2}{*}{ Subtask 1.4} & Transporter Approvals \\
\hline & $\begin{array}{l}\text { Provides for document preparation of use of on-site truck tankers in order to transport liquid } \\
\text { waste generated during deactivation and transition activities to TSD facility in } 200 \text { Area. }\end{array}$ \\
\hline Subtask 1.5 & $\begin{array}{l}\text { Prepare } 340 \text { Complex Interim Safety Basis (ISB) Revision } \\
\text { Provides for document preparation for revising the } 340 \text { Complex ISB as a result of hazard } \\
\text { reduction during transition activities. }\end{array}$ \\
\hline \multirow[t]{2}{*}{ Subtask 1.6} & Revise Facility Effluent Monitoring Plan (FEMP) \\
\hline & Provides for the required update and revision of the 340 Complex FEMP. \\
\hline \multirow[t]{2}{*}{ Subtask 1.7} & Revise Criticality Safety Evaluation Report (CSER) \\
\hline & $\begin{array}{l}\text { Provides for the update and revision of the } 340 \text { Complex CSER based on source reduction as } \\
\text { a result of deactivation activities. }\end{array}$ \\
\hline \multirow[t]{2}{*}{ Subtask 1.8} & Prepare Interim Monitoring Plan \\
\hline & $\begin{array}{l}\text { Provides for preparation of an Interim Monitoring Plan that will be implemented for } \\
\text { surveillance and maintenance of } 340 \text { Complex systems, structures and components during } \\
\text { Phase I. }\end{array}$ \\
\hline \multirow[t]{2}{*}{ Subtask 1.9} & Prepare Notice of Construction Vault Clean out Work \\
\hline & $\begin{array}{l}\text { Provides for preparation of NOC Vault Clean out work. NOC addresses new activities that } \\
\text { have potential for increasing radioactive air emissions during deactivation. }\end{array}$ \\
\hline
\end{tabular}


HNF-2230 Rev. 0

Table 5-1. WBS Summary - Phase I Tasks. (Sheet 2 of 7 )

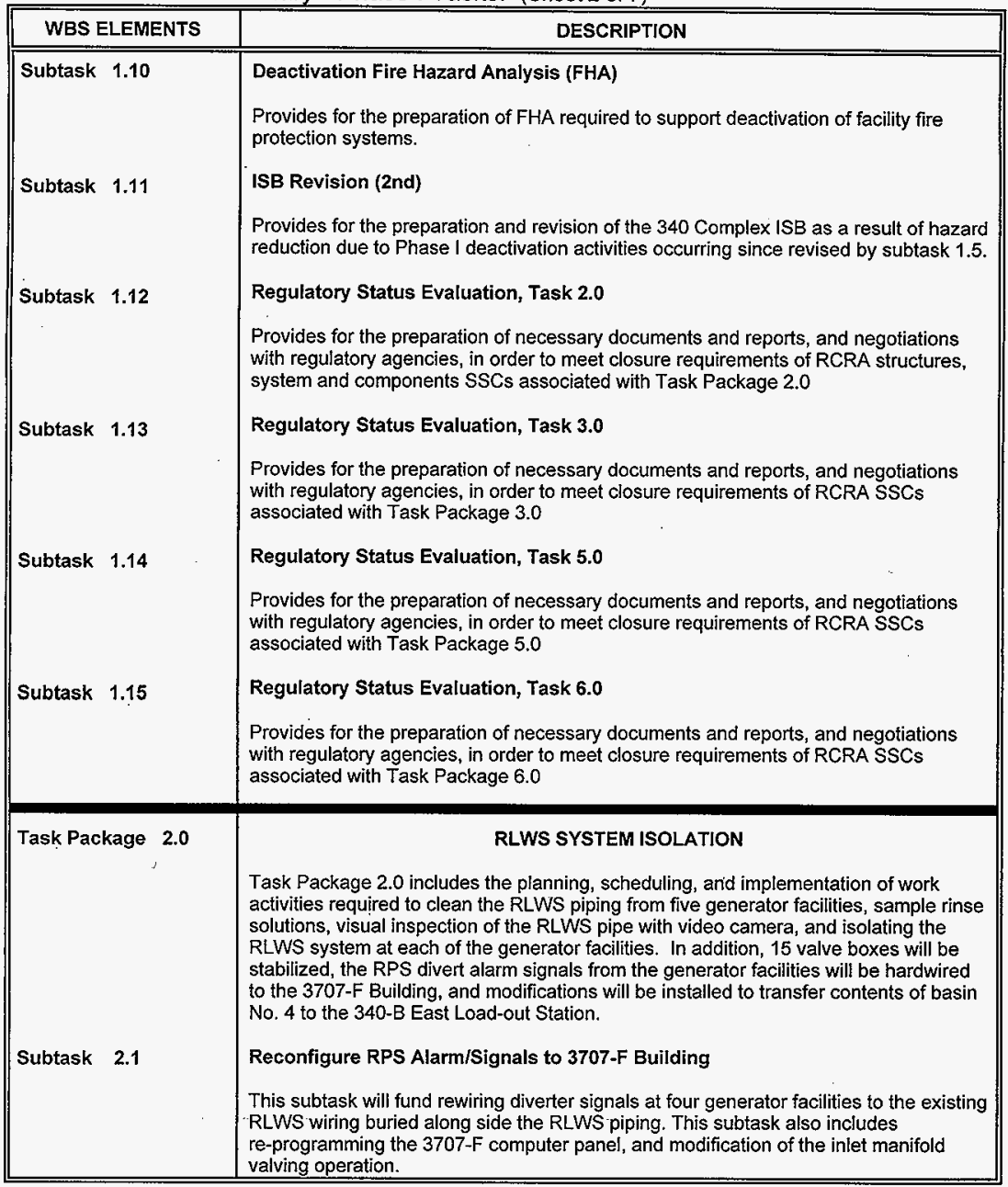


HNF-2230 Rev. 0

Table 5-1. WBS Summary - Phase I Tasks. (Sheet 3 of 7)

\begin{tabular}{|c|c|}
\hline WBS ELEMENTS & DESCRIPTION \\
\hline Subtask 2.2 & $\begin{array}{l}\text { Cap/lsolate RLWS Lines } \\
\text { This subtask will fund the isolation of the RLWS system at each of the generator } \\
\text { facilities. This subtask will involve breaking RLWS line and installing a blank } \\
\text { flange or cap inside each of the generator facilities. }\end{array}$ \\
\hline Subtask 2.3 & $\begin{array}{l}\text { Install RPS Reroute } \\
\text { This task will fund the design, planning, scheduling, and installation of the a RPS } \\
\text { by-pass piping from } 307 \text { Basin No. } 4 \text { to the } 340-B \text { East load-out station. This } \\
\text { system will allow the removal potentially contaminated liquid in Basin No. } 4 \\
\text { without having to go through the Vault tanks. }\end{array}$ \\
\hline Subtask 2.4 & $\begin{array}{l}\text { Decontaminate RLWS Piping } \\
\text { This subtask will fund removal of dangerous waste residues from the inside } \\
\text { surfaces approximately } 800 \mathrm{~m}(2,600 \mathrm{ft}) \text { of RLWS piping using high pressure } \\
\text { water sprays, performing final rinse of system piping, and collecting samples of } \\
\text { rinse solutions. }\end{array}$ \\
\hline Subtask 2.5 & $\begin{array}{l}\text { Inspect Lines } \\
\text { This subtask will fund the inspection of approximately } 800 \mathrm{~m}(2,600 \mathrm{ft}) \text { of RLWS } \\
\text { piping with a video camera. }\end{array}$ \\
\hline Subtask 2.6 & $\begin{array}{l}\text { Stabilize RLWS Valve Boxes } \\
\text { This subtask will fund the stabilization of } 15 \text { valve boxes associated with the } \\
\text { RLWS piping system. Stabilization activities include inspecting and documenting } \\
\text { condition of valve box interior surfaces, locking out the RLWS valving, and de- } \\
\text { energizing the alarm signal panels exterior to the valve boxes. }\end{array}$ \\
\hline Subtask 2.7 & $\begin{array}{l}\text { Document Turnover Package Items } \\
\text { This subtask will fund compiling and maintaining the central file for documents } \\
\text { generated during Phase I deactivation and transition activities. }\end{array}$ \\
\hline \multirow[t]{2}{*}{ Task Package 3.0} & 340 BUILDING DECON AREA STABILIZATION \\
\hline & $\begin{array}{l}\text { Task Package } 3.0 \text { includes the planning, scheduling, and implementation of work } \\
\text { activities required to place the } 340 \text { Building Decon Area in a standby status. } \\
\text { Activities required to complete this task include decontamination, system isolation, } \\
\text { radiological surveys, re-posting area status, housekeeping, and building isolation. }\end{array}$ \\
\hline \multirow[t]{2}{*}{ Subtask 3.1} & Decontaminate RLWS Related Systems and Components \\
\hline & $\begin{array}{l}\text { This subtask will fund the removal of dangerous waste residues from the sump } \\
\text { and connecting lines to Valve Box No. } 9 \text { using high pressure water sprays, and } \\
\text { video inspection. }\end{array}$ \\
\hline \multirow[t]{2}{*}{ Subtask 3.2} & RLWS System Isolation \\
\hline & $\begin{array}{l}\text { This subtask will fund the removal and isolation of the RLWS sample line, hood } \\
\text { sink drain line, decon sink and drain line, emergency shower station, sump pump } \\
\text { and sump liner, and Process Water back-flow preventer drain line. }\end{array}$ \\
\hline
\end{tabular}


HNF-2230 Rev. 0

Table 5-1. WBS Summary - Phase I Tasks. (Sheet 4 of 7)

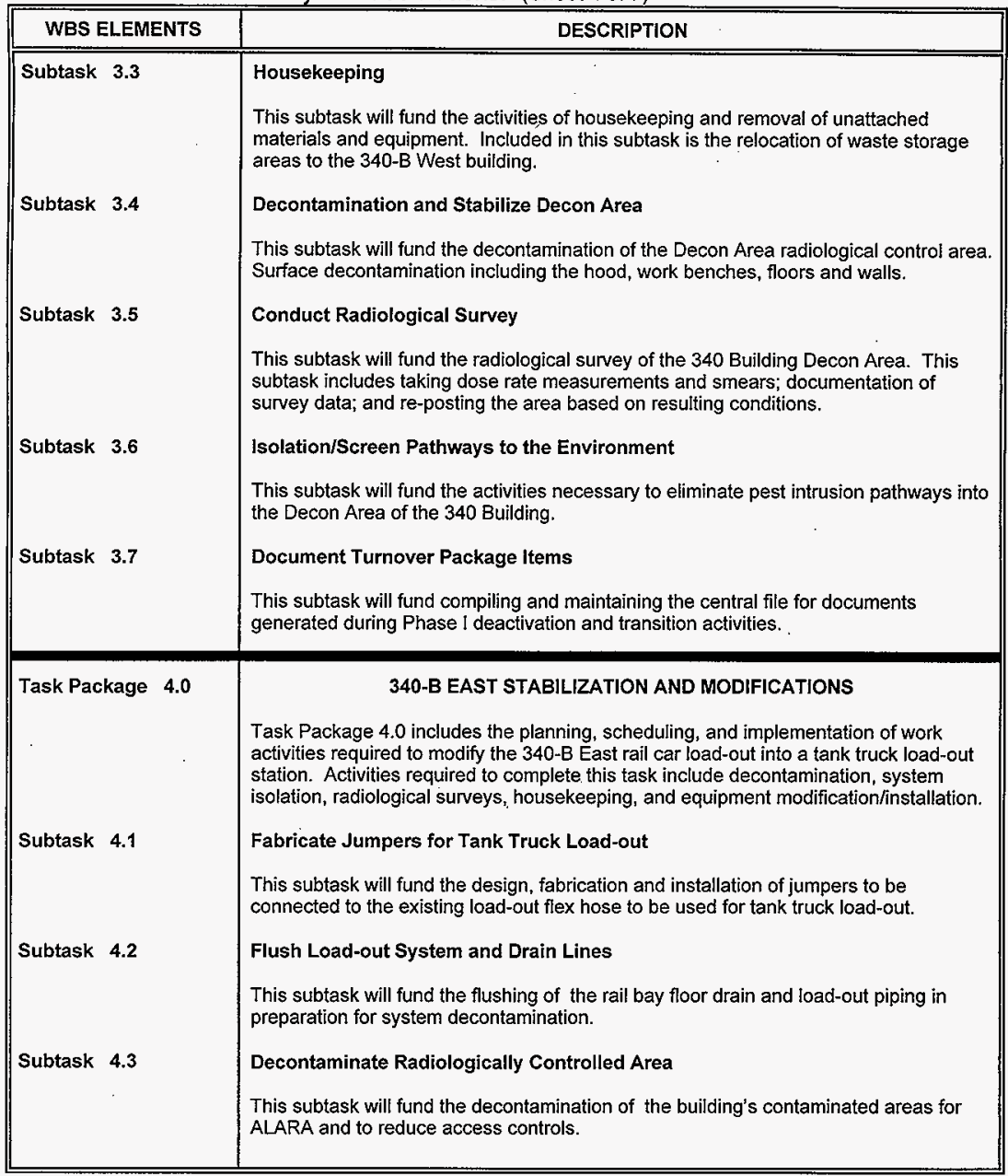


HNF-2230 Rev. 0

Table 5-1. WBS Summary - Phase I Tasks. (Sheet 5 of 7)

\begin{tabular}{|c|c|}
\hline WBS ELEMENTS & DESCRIPTION \\
\hline Subtask 4.5 & $\begin{array}{l}\text { Conduct Radiological Survey } \\
\text { This subtask will fund the radiological survey of the 340-B East Building. This subtask } \\
\text { includes taking dose rate measurements and smears; documentation of survey data; } \\
\text { and re-posting the area based on current conditions resulting after prior subtasks. } \\
\text { Document Turnover Package Items } \\
\text { This subtask will fund compiling and maintaining the central file for documents } \\
\text { generated during Phase I deactivation and transition activities. }\end{array}$ \\
\hline Task Package 5.0 & $\begin{array}{l}\text { 340-A BUILDING DEACTIVATION } \\
\text { Task Package } 5.0 \text { includes the planning, scheduling, and implementation of work } \\
\text { activities required to deactivate the } 340-A \text { Building. Activities required to complete this } \\
\text { task include decontamination, visual inspection, system isolation, radiological surveys, } \\
\text { and housekeeping. }\end{array}$ \\
\hline Subtask 5.1 & $\begin{array}{l}\text { Decontaminate Controlled Area } \\
\text { This subtask will fund decontamination of the interior surfaces of the } 340-A \text { Building. }\end{array}$ \\
\hline Subtask 5.2 & $\begin{array}{l}\text { Decontaminate 340-A Tanks } \\
\text { This subtask will fund the removal of dangerous waste residues, heel removal and } \\
\text { rinsing of the 340-A tanks and using high pressure water sprays. }\end{array}$ \\
\hline Subtask 5.3 & $\begin{array}{l}\text { Visual Inspection of Tanks } \\
\text { This subtask will fund the visual inspection of the } 340-A \text { tanks with remote video } \\
\text { camera system. }\end{array}$ \\
\hline Subtask 5.4 & $\begin{array}{l}\text { Decontaminate Piping and Inspect with Video Camera } \\
\text { This subtask will fund the decontamination of the tank transfer piping to the Vault using } \\
\text { EPA-approved physical extraction technology and visual inspection with remote video } \\
\text { camera. }\end{array}$ \\
\hline Subtask 5.5 & $\begin{array}{l}\text { Isolate Tanks, Drains, and Vent Lines } \\
\text { This subtask will fund the isolation of all tank penetrations and the drain and vent lines } \\
\text { to the Vault tanks. In addition, the } 340-A \text { sump drain line will be capped. }\end{array}$ \\
\hline Subtask 5.6 & $\begin{array}{l}\text { Housekeeping } \\
\text { This subtask will fund the activities of housekeeping and removal of unattached } \\
\text { materials and equipment. }\end{array}$ \\
\hline Subtask 5.7 & $\begin{array}{l}\text { Conduct Radiological Survey } \\
\text { This subtask will fund the radiological survey of the } 340-A \text { Building. This subtask } \\
\text { includes taking dose rate measurements and smears; documentation of survey data; } \\
\text { and re-posting the area based on resulting conditions. }\end{array}$ \\
\hline
\end{tabular}


HNF-2230 Rev. 0

Table 5-1. WBS Summary - Phase I Tasks. (Sheet 6 of 7)

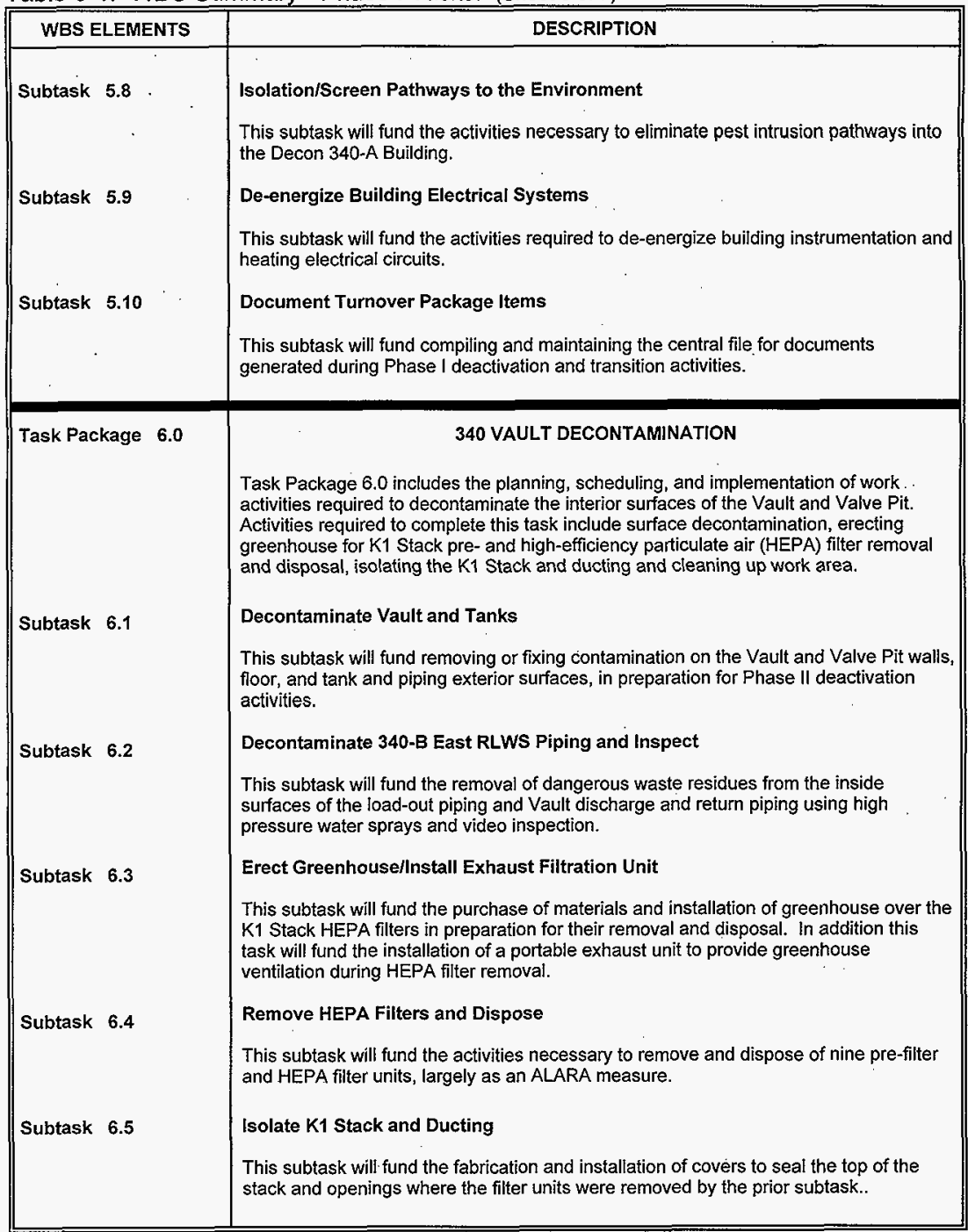


HNF-2230 Rev. 0

Table 5-1. WBS Summary - Phase I Tasks. (Sheet 7 of 7)

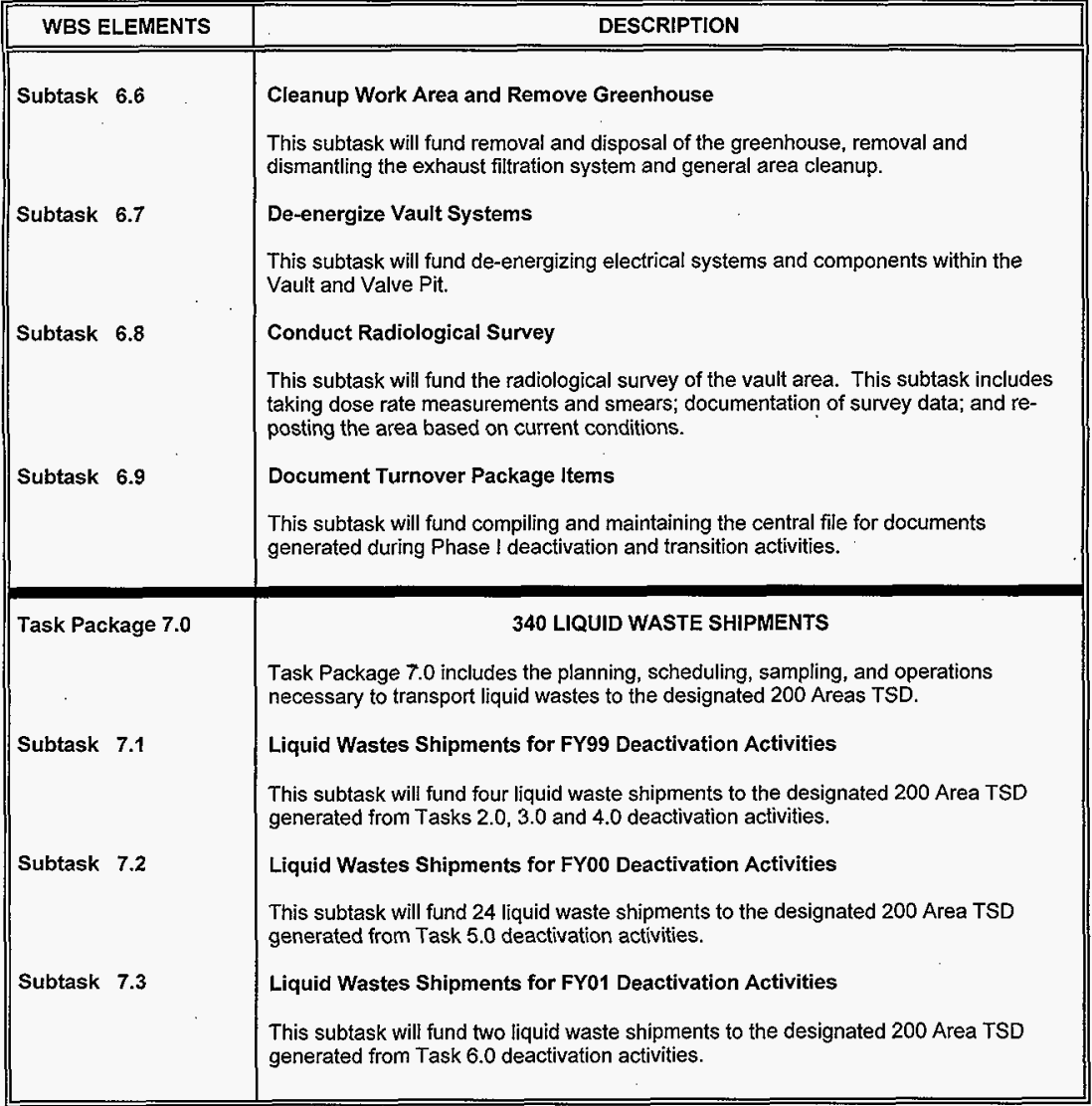


HNF-2230 Rev. 0

Table 5-2. WBS Summary - Phase II Tasks. (Sheet 1 of 3)

\begin{tabular}{|c|c|}
\hline WBS ELEMENTS & DESCRIPTION \\
\hline $\begin{array}{c}\text { TASK } 1.0 \\
\text { Subtask } \\
1 \\
2 \\
3 \\
4 \\
5 \\
6 \\
7 \\
8 \\
9 \\
10\end{array}$ & $\begin{array}{l}\qquad \text { DOCUMENTATION } \\
\text { Prepare Surveillance and Maintenance Plan } \\
\text { Prepare Final Endpoint Criteria Document } \\
\text { Revise PMP to reflect results of Phase I and Final EPC } \\
\text { Prepare NOC for Tank Removal Task } \\
\text { Maintain Turnover Package File } \\
\text { Prepare Final FHA Revision } \\
\text { Conduct Roof and Structural Analysis (Refurbishments not anticipated) } \\
\text { Prepare Asbestos Assessment for Vault } \\
\text { Prepare final safety basis } \\
\text { Miscellaneous: National Environmental Policy Act (NEPA), Tri-Party } \\
\text { Agreement, etc. }\end{array}$ \\
\hline $\begin{array}{c}\text { TASK } 2.0 \\
\text { Subtask } \\
1 \\
2 \\
3 \\
4 \\
5 \\
6 \\
7 \\
8 \\
9 \\
10 \\
11 \\
12 \\
13 \\
14 \\
15 \\
16 \\
17\end{array}$ & $\begin{array}{l}\text { VAULT AND VALVE PIT DEACTIVATION } \\
\text { Stage Work Area (for cover block removal, greenhouse install) } \\
\text { Remove and Dispose of Penthouses } \\
\text { Remove Cover Blocks and Stage } \\
\text { Install Greenhouse and Exhaust Filter Unit } \\
\text { Disconnect Tank Piping and Cap Openings } \\
\text { Drain Lube Oil Pump and Reservoir, and Isolate System } \\
\text { Cap Vault Penetrations } \\
\text { Isolate Electrical Power, except to Leak Detector } \\
\text { Remove Tanks and Prepare for Shipment } \\
\text { Process Tanks at TSD and dispose } \\
\text { Decontaminate Vault and Valve Pit Surfaces } \\
\text { Conduct Radiological Survey } \\
\text { Reconfigure Sump Leak Detection to ERC Criteria } \\
\text { Remove Greenhouse and Exhaust Filter Unit } \\
\text { Replace Vault Cover Blocks, Seal } \text { Weatherproof Hatches } \\
\text { Demobilize Work Area } \\
\text { Document and Close-out EPC }\end{array}$ \\
\hline $\begin{array}{c}\text { TASK } 3.0 \\
\text { Subtask } \\
1 \\
2 \\
3 \\
4 \\
5 \\
6 \\
7 \\
8 \\
9 \\
10\end{array}$ & $\begin{array}{l}\qquad 340 \text { CONTROL ROOM DEACTIVATION } \\
\text { Housekeep and Remove Unattached Material and Equipment } \\
\text { Deactivate Air Dryer System } \\
\text { Deactivate Control Panel } \\
\text { Clean out Sump/Pit } \\
\text { Deactivate heating, ventilating, and air conditioning (HVAC) } \\
\text { Isolate Utilities } \\
\text { Post Radiological and Safety Conditions } \\
\text { Isolate Pathways to and from Environment } \\
\text { Implement Access Control Requirements } \\
\text { Document and Close-out EPC }\end{array}$ \\
\hline
\end{tabular}


HNF-2230 Rev. 0

Table 5-2. WBS Summary - Phase II Tasks. (Sheet 2 of 3 )

\begin{tabular}{|c|c|}
\hline WBS ELEMENTS & DESCRIPTION \\
\hline $\begin{array}{c}\text { TASK } 4.0 \\
\text { Subtask } \\
1 \\
2 \\
3 \\
4 \\
5 \\
6 \\
7 \\
8 \\
9 \\
10\end{array}$ & $\begin{array}{l}\qquad 340 \text { MECHANICAL EQUIPMENT ROOM DEACTIVATION } \\
\text { Housekeep and Remove Unattached Material and Equipment } \\
\text { Remove and Dispose of Temporary Shielding } \\
\text { Remove/Fix/Contain Radioactive Contamination } \\
\text { Deactivate Air Compressor System and Vacuum Pumps } \\
\text { Deactivate Swamp Cooler } \\
\text { Isolate Utilities } \\
\text { Post Radiological and Safety Conditions } \\
\text { Isolate Pathways to and from Environment } \\
\text { Implement Access Control Requirements } \\
\text { Document and Close-out EPC }\end{array}$ \\
\hline $\begin{array}{c}\text { TASK } 5.0 \\
\text { Subtask } \\
1 \\
2 \\
3 \\
4 \\
5 \\
6 \\
7\end{array}$ & $\begin{array}{l}\qquad \text { DEACTIVATE } 340 \text { BUILDING DECON AREA } \\
\text { Housekeep and Remove Unattached Material and Equipment } \\
\text { Isolate Hood } \\
\text { Remove K3 Ventilation System Pre-filters } \\
\text { Conduct Final Radiological Survey and Post Conditions } \\
\text { Isolate Pathways to and from Environment } \\
\text { Implement Access Control Requirements } \\
\text { Document and Close-out EPC }\end{array}$ \\
\hline $\begin{array}{c}\text { TASK } 6.0 \\
\text { Subtask } \\
1 \\
2 \\
3 \\
4 \\
5 \\
6 \\
7 \\
8 \\
9\end{array}$ & $\begin{array}{l}\text { DEACTIVATE } 340 \text { TRUCK LOCK, MEZZANINE \& LOCKER ROOMS } \\
\text { Housekeep and Remove Unattached Material and Equipment } \\
\text { Deactivate K3 Ventilation System } \\
\text { Deactivate Fire Sprinkler System (Truck Lock, Decon Area, Control } \\
\text { Room) } \\
\text { isolate Roll up Door in Truck Lock } \\
\text { Isolate/Seal Drains to Sanitary Sewer } \\
\text { Isolate/Screen Locker Room Exhaust Fan Openings } \\
\text { Isolate Pathways to and from Environment } \\
\text { Implement Access Control Requirements } \\
\text { Document and Close-out EPC }\end{array}$ \\
\hline $\begin{array}{c}\text { TASK } 7.0 \\
\text { Subtask } \\
1 \\
2 \\
3 \\
4 \\
5 \\
6 \\
7 \\
8 \\
9\end{array}$ & $\begin{array}{l}\text { DEACTIVATE } 340-B \text { BUILDING } \\
\text { Housekeep and Remove Unattached Material and Equipment } \\
\text { Deactivate K2 Ventilation System } \\
\text { Deactivate Fire Sprinkler System } \\
\text { Isolate Roll up Doors } \\
\text { Conduct Final Radiological Survey and Post Conditions } \\
\text { Isolate Floor Drains } \\
\text { Isolate Pathways to and from Environment } \\
\text { Implement Access Control Requirements } \\
\text { Document and Close-out EPC }\end{array}$ \\
\hline
\end{tabular}


HNF-2230 Rev. 0

Table 5-2. WBS Summary - Phase II Tasks. (Sheet 3 of 3)

\begin{tabular}{|c|c|}
\hline WBS ELEMENTS & DESCRIPTION \\
\hline $\begin{array}{l}\text { TASK } 8.0 \\
\text { Subtask } \\
1 \\
2 \\
3 \\
4 \\
5 \\
6\end{array}$ & $\begin{array}{l}\text { 3707-F BUILDING DEACTIVATION } \\
\text { Housekeep and Remove Unattached Material and Equipment } \\
\text { Isolate Utitities } \\
\text { Conduct Final Radiological Survey and Post Conditions } \\
\text { Isolate Pathways to and from Environment } \\
\text { Implement Access Control Requirements } \\
\text { Document and Close-out EPC }\end{array}$ \\
\hline $\begin{array}{c}\text { TASK } 9.0 \\
\text { Subtask } \\
1 \\
2 \\
3 \\
4 \\
5 \\
6 \\
7\end{array}$ & $\begin{array}{l}\qquad 307 \text { BASIN DEACTIVATION } \\
\text { Housekeep and Remove Unattached Material and Equipment } \\
\text { Conduct Final Radiological Survey and Post Conditions } \\
\text { Decontaminate/Fix Removable Contamination as Applicable } \\
\text { Isolate Utilities } \\
\text { Post Hazards, in accordance with EPC } \\
\text { Implement Access Control Requirements (will retain function as local } \\
\text { storm sewer reservoir) } \\
\text { Document and Close-out EPC }\end{array}$ \\
\hline $\begin{array}{c}\text { TASK } 10.0 \\
\text { Subtask } \\
1 \\
2 \\
3 \\
4 \\
5 \\
6 \\
7\end{array}$ & $\begin{array}{l}\text { BALANCE OF COMPLEX DEACTIVATION } \\
\text { Deactivate MO-036 (turnover to Site Services) } \\
\text { Deactivate MO-741 (turnover to Site Services) } \\
\text { Stabilize Yard (Outside Area: Cinder Block Building, RPS Pit, valve } \\
\text { boxes, non-process sewer manholes, etc.) } \\
\text { Remove/Dispose of Storage Conexs (or SeaLand containers) } \\
\text { Isolate Pathways to and from Environment } \\
\text { Implement Access Control Requirements } \\
\text { Document and Close-out EPC }\end{array}$ \\
\hline $\begin{array}{c}\text { TASK } 11.0 \\
\text { Subtask } \\
1\end{array}$ & $\begin{array}{l}\text { FINAL DEACTIVATION OF 340-A BUILDING } \\
\text { Document and Close-out EPC }\end{array}$ \\
\hline $\begin{array}{c}\text { TASK } 12.0 \\
\text { Subtask } \\
1 \\
2 \\
3\end{array}$ & $\begin{array}{l}\text { FACILITY TRANSFER TO ERC } \\
\text { Consolidate closed-out EPC document, submit to ERC } \\
\text { Final assembly of turn-over package; convey to ERC } \\
\text { Prepare final transfer paperwork; official turn-over to ERC }\end{array}$ \\
\hline TBD & $\begin{array}{l}\text { (POSSIBLE RLWS REMOVAL, AGS TANK REMOVAL \& PAD } \\
\text { DECON) }\end{array}$ \\
\hline
\end{tabular}


HNF-2230 Rev. 0

This page intentionally without substantive content. 


\subsection{BASELINE}

The preliminary 340 Complex Transition Task baseline is developed and presented in Figure 6-1. The baseline establishes the duration for the transition tasks in accordance with work breakdown structure (WBS). Specific authorization for each task and subtask is established through the preparation of a detailed basis of estimate (BOE) and resource loaded schedule. These, in turn, are validated and used as the basis for the budget request in the multi-year work plan (MYWP). Once the MYWP is approved, cost account plans (CAPs) are prepared. This plan specifies milestones and deliverables, establishes both short-term and long-term schedules, and provides details on the financial, human, and material resources needed to accomplish the transition work according to the established schedules. It forms the task baseline in terms of both cost and schedules, and serves as the vehicle for obtaining RL approval of the planned transition work. Section 5.0 describes how revisions to the baseline are accomplished.

Task progress and cost schedule performance information will be monitored and reported through formal monthly performance reporting. Specific task activities and accomplishments will be tracked and reported in weekly highlights as well as at routine status review meetings held to discuss problem areas, progress, and assigned action items. The current baseline schedule (summary level) for the multi-year transition phase is Figure 6-1. Appendix D provides a greater level of scheduling detail for Phase I only.

The schedule duration for Phase $I$ is about 40 months, and the estimated cost is $\$ 2.96$ million, including contingency of $30 \%$, and general and administrative (G\&A) and other overhead adders. The Phase II duration could be as short as 36 months or may be spread out over many more years, depending upon the length of the RPS operating mission, funding for major tasks such as tank removal and vault decon, and negotiated closure agreements. The rough cost estimate for Phase II is $\$ 2.0$ million, with the possibility of an additional $\$ 3.9$ million if the above ground storage (AGS) tanks and RLWS piping and valve boxes need to be retrieved and disposed prior to turnover of the Complex to the ERC; all including contingency (35\%; reflecting the greater uncertainty noted in section 5.0) and G\&A.

Phase I milestones include [with individual task effective completion dates indicated]:

- Isolate (cap) the RLWS at generating facilities: November 30, 1998,

- Fabricate new truck/transport load-out jumpers for 340-B: January 8, 1999,

- Revise the 340 authorization basis to reflect new facility status: April 2, 1999,

- Stabilize valve boxes [task 2.0]: September 30, 1999.

- Deactivate 340 Bldg Decon Area [task 3.0]: November 16, 1999.

- Stabilize 340-B East [task 4.0]: December 14, 1999.

- Deactivate 340-A building [task 5.0]: September 28, 2000,

- Isolate K1 stack and dispose of HEPA filters: June 13, 2001, and

- De-energize 340 Vault systems [task 6.0] July 13, 2001. 


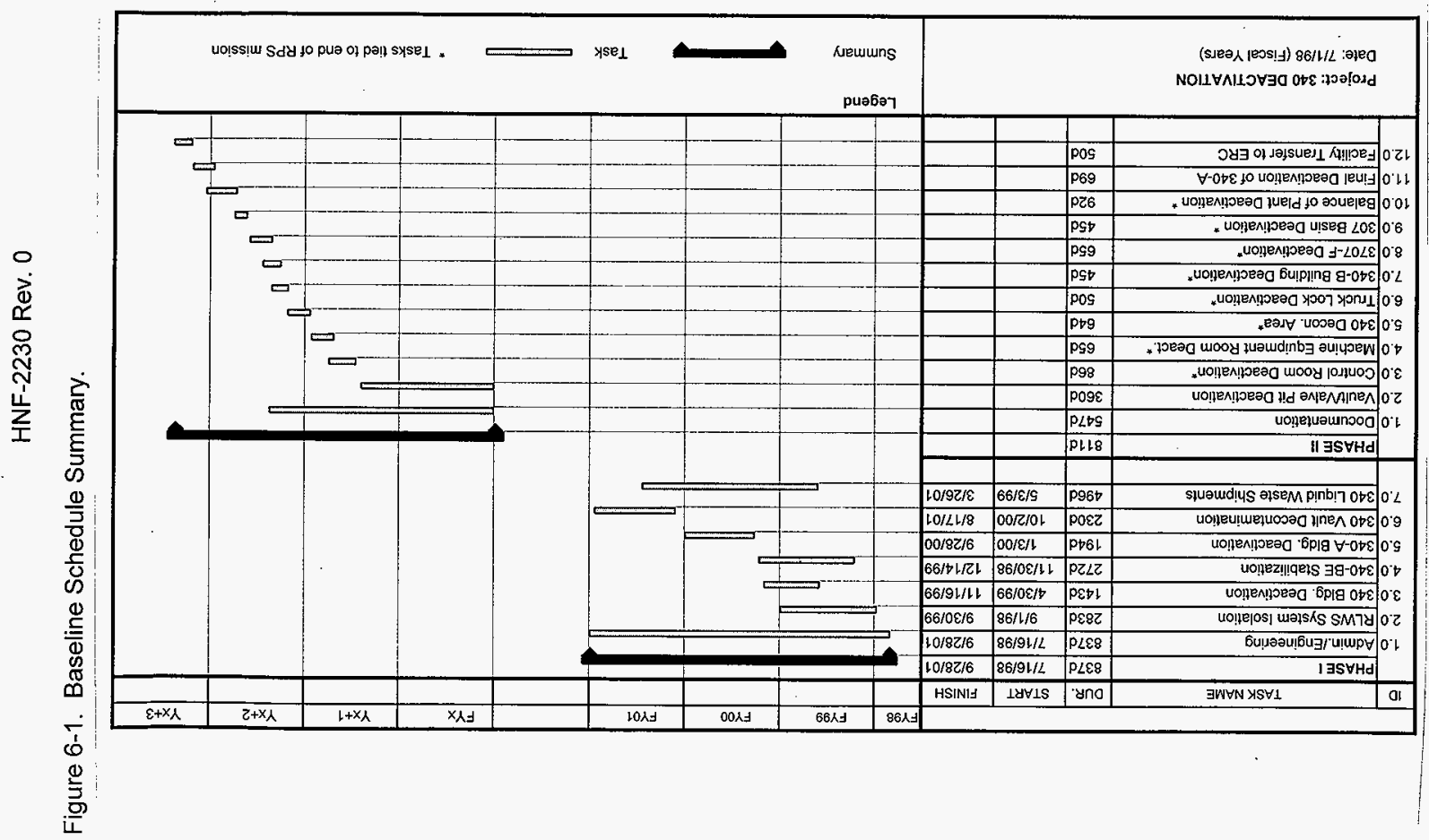


HNF-2230 Rev. 0

\subsection{ENDPOINTS SUMMARY}

\subsection{Background}

The endpoint method is a logical process of determining final conditions for each of the 340 Complex systems and spaces. The final conditions are based on stated objectives, likely task types, and expected future uses for the systems and spaces. This method was used in preparing Appendix $E$, and will be used to create Appendix $F$.

\subsection{Endpoint Development Principles}

Several guiding principles form the foundation of the endpoint process:

- Endpoint determinations, along with allocation of resources and selection of methods, should all stem directly and clearly from program goals and top-tier objectives;

- The endpoint condition of the 340 Complex should employ a fundamental safety approach which involves three layers of protection: elimination of hazards, effective facility containment, and facility monitoring and control;

- Endpoint decisions are integrally linked to decisions (and constraints) on resources and methods of which cost-effectiveness is important;

- A successful endpoint development requires ownership by all affected organizations including project planners, those who implement the plans, and the ultimate customer, EM-40;

- Work teams in the field need clear, quantitative endpoints; they cannot work effectively with vague or functional objectives;

- It is not known when or what the ultimate facility disposition will be; therefore, endpoint decisions should not be driven by dispositioning presumptions; and,

- Endpoint development is an interactive process; some endpoint decisions may have to be revisited as the stabilization proceeds.

\subsection{Endpoint Development Methodology}

Every endpoint is driven by an objective; therefore, the first step defines the top-level project objectives which will then form the objectives for the endpoints. For the 340 Complex these objectives are:

- Protect the public and environment, 
- Facilitate S\&M, protect workers and reduce cost,

- Facilitate decommissioning, and

- Comply with regulations and requirements.

Task types are the series of tasks which take the facility from its existing state, with hazards and conditions resulting from its lifetime of operation, to its deactivated state. For the 340 Complex stabilization, the following task types are used throughout the endpoint development process:

Hazards - nuclear and nonnuclear; activities include removing, isolating, and draining;

Radiation Fields - activities include removing, shielding, documenting, and ensuring the proper radiological posting of remaining radiation areas;

Contamination - activities include decontaminating, isolating, fixing, documenting and ensuring the proper radiological posting of remaining contamination areas;

Waste - compliance with regulations and requirements generates activities that include removing, flushing, excessing and disposing of waste;

Isolate and Contain - activities include blanking, plugging, covering, removing, screening, and sealing;

Monitor and Control - provides the necessary activities required to support and minimize the cost, risk and hazards involved with the future S\&M of the complex, such as instrumentation and providing surveillance lighting;

Refurbish or Install - activities include structural repairs and roof sealing and modification of the complex ventilation systems; and

Document and Label - activities cover the documentation and labeling for specific space or system.

Next, the spaces and systems that comprise the 340 Complex are classified, in terms of their intended deactivated condition, into the following cases:

Case 1, Internal Spaces, Routine Access Required - a space internal to the building where access will be required for surveillance;

Case 2, Internal Spaces, No Access Expected - a space internal to the building where access will not be required for surveillance, but can be accessed if the proper precautions are taken; 
HNF-2230 Rev. 0

Case 3, External Spaces, Including Building Exterior Envelopes - areas assigned to Complex that are in direct contact with the environment;

Case 4, Operational Systems - systems supporting the complex that will remain operational;

Case 5, Mothballed Systems - complex systems that will be laid-up for future reuse by the ERC; and

Case 6, Systems, Abandoned in Place - complex systems that will be left in place after the assigned endpoints have been completed.

The endpoint methods described above are not intended to be prescriptive in nature, but are to be adapted to suit the specific needs of the complex under stabilization. Detailed endpoints for each of the buildings in the 340 Complex are contained in the Interim Endpoint Specification Document, Appendix E.

\subsection{Endpoint Administration}

Eventual completion and verification of the 340 Complex endpoints during Phase II by both the DOE EM-30 Contractor WMH and the DOE EM-40 ERC Bechtel Hanford, Inc. $(\mathrm{BHI})$, is required to complete the facility transition phase and initiate the Surveillance and Maintenance (S\&M) phase of the Decommissioning Process. Upon ERC acceptance, the complex will be in a condition acceptable for the transfer from EM-30 to EM-40. A Memorandum of Agreement (MOA) will be required to delineate and transfer responsibilities for the future S\&M activities associated with the 340 Complex. The document will also describe the facility condition including environmental, safety and outstanding regulatory concerns.

\subsection{Endpoint Closure}

The endpoint document has grouped the complex spaces and systems into a number of manageable areas. These areas are closely related to the engineering work plans which guide completion of many of the endpoints.

Upon completion of an endpoint, a WMH field representative will initial 'complete' on the field copy of the endpoint document. A BHI/ERC field representative will then verify acceptable completion of the applicable activity. Verification may be performed by review of documents, letters, photos, work packages, work plans or visually. When all the endpoints for a specific area of the facility have been completed and verified, the designated $\mathrm{WMH}$ management along with ERC management will sign off completion and acceptance of that area. A filing system will be required for storage of the documentation closing endpoints. 
HNF-2230 Rev. 0

\subsection{Administrative Endpoints and Turnover Package}

Administrative endpoints are a compilation of identified supporting documentation for the transition of the 340 Complex into the Surplus Facility Program. An endpoint has been assigned to them for tracking and verification purposes only. The compilation includes those documents that are required by law, Tri-Party Agreement, DOE Orders, or have been identified by building management, the DOE and/or the ERC.

Additional supporting documentation is also included under the requirements of a turnover package. The turnover package activity supports the physical hands on documentation required for performance of future surveillance entries, audits and to assist disposition planning, i.e., final radiological surveys and maps. Turnover package items are addressed in the endpoints for the specific space or system where the requirement is applicable. The turnover package becomes even more critical under the 340 Complex two-phase approach, as careful documentation of Phase I measures can expedite the ultimate post-Phase II turnover.

Documents included with turnover packages are:

- Facility arrangement drawings,

- Certified vendor information (CVI),

- Chemical and hazardous substance inventory,

- Completed ECNs and signed deactivation work plans,

- Description, photos, and/or videos of Case 2 spaces,

- Electrical distribution drawings,

- Final radiological surveys and maps, HPT routine surveys,

- Industrial space hazards identification,

- Identification of Case 4 operational systems waste accumulation areas,

- Revision of structural and roof studies (e.g., McCoy 1993),

- FHA revision (e.g., Roberts 1995),

- Environmental permits, NEPA documentation, and RCRA/dangerous waste risk assessments,

- Compliance with the Hazards Communication Program,

- Compliance with the Asbestos Control Program,

- Compliance with the Confined Space Program, and

- Waste characterization data. 
HNF-2230 Rev. 0

\subsection{QUALITY ASSURANCE (QA)}

\subsection{Quality Assurance Program}

The management system currently in place to control quality at the 340 Facility will be used during the transition phase of the 340 Complex decommissioning. The quality program documents respond to the requirements of 10 CFR 830.120 , "Quality Assurance Requirements," the QA Rule. Implementation of the QA Rule occurs through a series of FDH and WMH documents, which are evolving as shown in Table 8-1.

The 340 Complex will be included in the waste management operations draft Standards/Requirements Identification Document (S/RID). No conflicts are anticipated among the requirements documents cited in the S/RIDs and the matrix attached to the WMH Quality Assurance Program Plan (QAPP). The QAPP responds to the requirements applicable to the 340 Complex.

Table 8-1. QA Document Changes.

\begin{tabular}{|c|c|}
\hline CURRENT DOCUMENTS & REPLACEMENT DOCUMENTS \\
\hline $\begin{array}{l}\text { WHC-SP-1131, Hanford Quality Assurance } \\
\text { Program and Implementation Plan (WHC 1996e). } \\
\text { WMH-MD-004, Extension of Portions of } \\
\text { WHC-CM-4-2 (WMH 1998b). }\end{array}$ & $\begin{array}{l}\text { HNF-SP-1228, Quality Assurance Program } \\
\text { Implementation Plan for Nuclear Facilities which is } \\
\text { awaiting approval by DOE-RL (FDH 1997b). } \\
\text { HNF-MP-599, Project Hanford Quality Assurance } \\
\text { Program Description, approved (FDH 1997h). }\end{array}$ \\
\hline $\begin{array}{l}\text { WHC-CM-4-2, Quality Assurance Manual } \\
\text { (WHC 1996d). } \\
\text { WMH-MD-004, Extension of Portions of } \\
\text { WHC-CM-4-2 (WMH 1998b). }\end{array}$ & $\begin{array}{l}\text { HNF-MP-599, Project Hanford Quality Assurance } \\
\text { Program Description, which became on } \\
\text { November } 1,1997, \text { the PHMC requirement } \\
\text { document for all nuclear-related and nonnuclear- } \\
\text { related Project Hanford activities. } \\
\text { HNF-SD-WM-QAPP-036, Quality Assurance } \\
\text { Program Plan, which is approved by WMH and } \\
\text { awaiting approval by FDH (WMH 1998c). }\end{array}$ \\
\hline
\end{tabular}

The requirements set forth in two PHMC procedures need to be anticipated prior to deactivation. HNF-PRO-1794, Facility Shutdown, Standby, and Transfer and HNF-PRO-443, Facility Deactivation Requirements describe activities to be completed during the transition to the ERC (FDH $1997 f$ and FDH 1997d).

\subsection{Personnel Training and Qualification}

It is anticipated that conditions and hazards encountered during deactivation activities will be similar to those encountered during normal operations. The facility will follow the DOE-RL approved WMH Training Implementation Matrix (TIM), which implements the requirements set forth in DOE Order 5480.20A, Personnel Selection, Qualification, and Training Requirements for DOE Nuclear Facilities. 
HNF-2230 Rev. 0

\subsection{Document and Records Control}

Document and record control procedures are described in the WMH QAPP (WMH 1998c). HNF-PRO-443, Facility Deactivation Requirements prescribe minimum information or documents that are to be included in the facility turnover files (FDH 1997d).

\subsection{Configuration Management}

HNF-MP-013 Configuration Management Plan describes the process that documents the functional and physical characteristics of items and how they change during their life cycle (FDH 1997g). Configuration management controls are described in the WMH QAPP (WMH 1998c). HNF-PRO-443, prescribes those activities to be accomplished during the deactivation phase (FDH 1997d). 
HNF-2230 Rev. 0

\subsection{REGULATORY AND ENVIRONMENTAL STRATEGY}

The following summary describes the approach to implementing regulatory requirements associated with deactivation of the 340 Complex, and to protect the public, workers, and the environment throughout the transition project.

The strategy for environmental compliance of the 340 Complex transition project begins with the partial ${ }^{1}$ application of the process described in the Tri-Party Agreement, Sixth Amendment, Section 8.0, "Facility Decommissioning Process" (Ecology et al. 1996). Section 8.0 contains Figure 8-1, Predecommissioning Planning, which identifies the decision path for determining the applicable decommissioning action.

The decision process is divided into three parts: Segregation, Prioritization, and Action. Segregation identifies whether or not there is a future mission for the facility; if the disposition is fully integrated in conjunction with an operable unit; and if the facility is a TSD unit. With regard to the 340 Complex, the voluntary receipt of waste transfers via the RLWS is scheduled to be terminated by the end of FY98. The 340 Complex is not now fully integrated in conjunction with an operable unit, and the Complex is not a TSD Unit.

Segregation leads to prioritization, i.e., the determination of whether or not the complex is a "Key" facility. In reference to DOE/RL-96-0046, Long-Term Facility

Decommissioning Plan, the 340 Complex has been listed as a "non-key" facility (DOE$\mathrm{RL} 1996 \mathrm{~b})$. Therefore, by definition the action decision for the 340 Complex is 'Decommissioning per Environmental Management (EM) Guidelines and other applicable regulations.' The primary source of EM guidance is contained in DOE/EM0246, the Decommissioning Resource Manual (DOE 1995a). The predecommissioning planning decision path for the 340 Complex is illustrated in Figure 9-1, which is a reproduction of Figure 8-1 of the Tri-Party Agreement.

The 340 Complex is a generator waste accumulation (less-than-90-day) area. It is not a permitted TSD unit. However, specific dangerous waste rules and regulations apply with regard to closure actions of SSCs within the 340 Complex that have been contaminated with dangerous waste per the Washington Administrative Code (WAC) 173-303, specifically WAC 173-303-200(1)(b)(ii).

The overall goal of this strategy is to comply with all applicable environmental laws and regulations during Complex transition, and to apply the lessons learned from other deactivation projects for environmental and regulatory process improvement.

' Lack of a formal DOE-HQ shutdown decision, Section 1.4.1, results in an immediate deviation from Section 8 (Tri-Party Agreement). In addition, RL has determined that EM-30 will directly transition the 340 Complex to EM-40. 
Figure 8.1, Predecommissioning Planning (TPA Action Plan, Section 8.0)

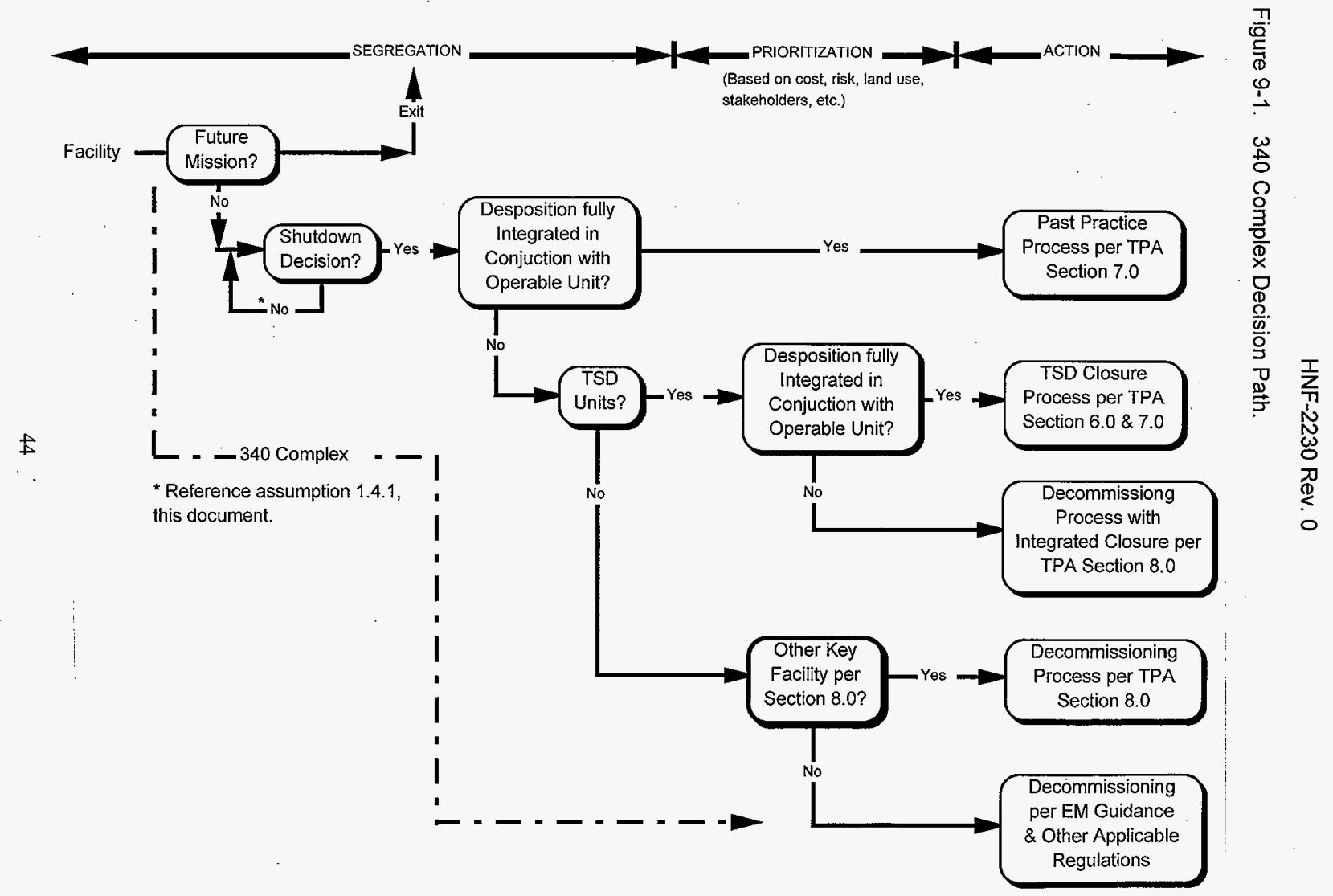


HNF-2230 Rev, 0

\subsection{Dangerous Waste Status and Strategy}

Dangerous waste requirements for the 340 Complex apply to the RLWS system piping and valve boxes, the 340 Vault and Valve Pit, the 340-A Building tanks and foundation, components of the 340 Building Decon Area, and the 340-B Building load-out facility. The 340 Vault contains two waste receiving tanks and the 340-A Building contains six above ground storage tanks.

\subsubsection{Regulatory Status of the $\mathbf{3 4 0}$ Complex}

The 340 Complex regulatory status and anticipated closure requirements under WAC 173-303, dangerous waste regulations, include:

- The 340 Complex is a 90-day waste accumulation tank system. Operation of the 340 Complex falls under the provisions of WAC 173-303-200(1)(b)(ii) for generator accumulation of waste for "90 days or less," WAC 173-303-200(1)(a).

- The 340 Complex is not required to have a dangerous waste permit, i.e., Part B permit or Part A for permitted interim status.

- Closure of the RLWS system must meet the requirements of the WAC 173-303-610(2), WAC 173-303-610(5), and WAC 173-303-640(8) with the exception of (8)(c) and the second sentence of (8)(a).

- The fundamental closure requirement is to remove or decontaminate all waste residues and components, soils, structures, and equipment contaminated with dangerous waste and manage them as dangerous waste unless WAC 173-303-070(2)(a) applies, i.e., the waste does not designate upon generation.

- The following closure requirements for permitted TSD units DO NOT apply:

- Closure plan (and schedule) per WAC 173-303-610(3)(a),

- Closure notification (partial and final closure) per WAC 173-303-610(3)(c),

- Requirements to begin closure within 90 days of last receipt of the final volume of waste dated per WAC 173-303-610(4)(a),

- Requirements to complete closure activities in 180 days per WAC 173-303$610(4)(\mathrm{b})$, and

- Closure certification per WAC 173-303-610(6).

Although a formal Ecology-approved closure plan is not required, nor currently being pursued by Ecology in this case, they will be notified of the intention to deactivate the unit, the plan to meet closure requirements, and how closure activities will be verified and documented.

- The closure requirements for piping and ancillary equipment are basically the same as for the tanks. 
- The 340 Complex tank system may designate as hazardous debris upon generation without a 'contained-in' determination from Ecology which is codified for debris in WAC 173-303-070(2)(c) and provided for in Ecology Clean Closure Guidance (Ecology 1994) and for EPA in 40 CFR 261.3(f). This debris would designate as hazardous under the waste designation requirements of WAC 173-303-070(3)(a) and WAC 173-303-070(5) due to contact with listed waste per WAC 173-303-082 and the subsequent application of the mixture rule without land disposal restrictions (LDR) treatment or an Ecology/EPA 'contained-in' determination representative of all contaminated surfaces to remove the listed waste codes.

- The 340 Complex tank system hazardous debris could undergo specific LDR treatment prior to land disposal.

- A tank is 'empty' for accumulation purposes when it is drained to fullest possible extent using normal operating methods and equipment. One hundred percent of the waste will not always be removed; so, as general guidance, a tank should be considered empty when the generator has left the tank's drainage system open until a steady, continuous flow has ceased. This could mean gravity draining or normal system mechanical pumpdown.

- 'Empty' does not equate to 'closed' and ready for disposal. Ecology regulation requires closure upon completion of use as a 90-day accumulation unit and prior to its disposal or non-regulated reuse.

- All closure waste, such as residues and rinsates, must be managed in accordance with all applicable waste generator requirements of WAC 173-303.

In addition, several commitments were made to Ecology to close-out some noncompliance issues with dangerous waste tank system requirements via Letter 95-PCA342, dated July 6, 1995 from J.D. Wagoner (RL) to D. Silver (Ecology) (DOE-RL 1995b).

- Cease receiving liquid waste transfers in September 1998 when shutdown begins,

- Maintain and continuously monitor leak detection and monitoring systems,

- Remove spilled waste from secondary containment systems within $24 \mathrm{hr}$, and

- Maintain continuous leak detection monitoring for the double-wall RLWS pipe upstream of valve box No. 9 .

\subsubsection{Complex Closure Strategy}

The goal for regulatory compliance is to clean close the components of the 340 Complex which have been contaminated with dangerous waste, following cleaning to 
meet performance standards of the Debris Rule in 40 CFR 268.452. Ecology has chosen to reference the alternative treatment standards for hazardous debris as the minimum contamination standard for closure. Table 9.1, summarizes this closure strategy. It is anticipated that compliance can be achieved under the two-phased approach formulated in this PMP. Most of the structures remain after Phase I and Phase II deactivation, and include: the RLWS piping and valve boxes, the 340-A Building (with tanks), 340 Vault and Valve Pit, 340 Building, 3707-F, 307 basins, and the 340-B Building [the office trailers will be turned over to Site Services for removal - if the ERC has no further use for them].

There are approximately $800 \mathrm{~m}(2,600 \mathrm{ft})$ of buried RLWS piping and 15 valve boxes, that fall within the scope of the 340 Complex deactivation, lying between the five generator facilities and the 340 Vault. There is also approximately $60 \mathrm{~m} \mathrm{(200} \mathrm{ft)} \mathrm{of}$ buried RLWS piping between the Vault and the various buildings within the 340 fence line. The closure strategy for the buried double-wall RLWS piping is to clean the interior of the piping to clean debris surface standard and verify there has been no release of dangerous waste which could have contaminated other portions of the piping system. The piping will be clean closed in place and mothballed until removal can be coordinated with other removal actions in the 300-FF-2 operable unit. The EPARichland Office has CERCLA authority and will be involved in any decisions regarding possible remediation undertaken as part of this operable unit.

If clean closure for the buried RLWS is not an achievable strategy, negotiation of an alternate schedule and funding to excavate the piping system would be required. The factors which will affect the final closure requirements for the RLWS piping include the following:

- The RLWS piping is located within the 300-FF-2 operable unit which contains several retired contaminated sewer systems. The RLWS piping is buried adjacent to or near these retired systems. The attempt to clean the RLWS piping to 'alternate debris standards' should result in a status that will present no environmental threat until final disposition under the $300-F F-2$ operable unit.

- Excavation of the RLWS system would have to be performed by hand due to the potential of heavy equipment disrupting the local infrastructure, e.g., active utility (electrical, natural gas, water, phone) or waste disposal (RPS, PS, sanitary) systems. It is not practical to remove the RLWS piping, when the majority of contaminated piping and soil will be remediated at some future date.

- There are no known or suspected releases of dangerous waste from the RLWS piping which could have contaminated exterior surfaces.

2 The EPA's alternate treatment standards for hazardous debris are expressed as methods of treatment. When a generator elects to use these alternate standards, the technology listed in Table 1 of 40 CFR 268.45 must be used to comply with the LDR treatment standards. 


\begin{tabular}{|c|c|c|c|c|}
\hline $\begin{array}{l}\text { Tanksystem } \\
\text { Component }\end{array}$ & $\begin{array}{l}\text { Estimated Quantity } \\
\text { Description }\end{array}$ & Regulatory Status 1 & Proposed Phase A Action & Proposed Phasell \\
\hline \multicolumn{5}{|l|}{ Dangerous Waste Piping } \\
\hline RLWS primary piping & $2,370 \mathrm{ft}$ SS pipe & Contaminated debris & $\begin{array}{l}\text { Use appropriate technology to remove } \\
\text { waste residues from internal surfaces, } \\
\text { visually verify clean internal surface. }\end{array}$ & $\begin{array}{l}\text { Determine regulatory status } \\
\text { and endpoint }{ }^{2}\end{array}$ \\
\hline RLWS 329 to VB1 primary piping & $150 \mathrm{ft}$ plastic pipe & Contaminated debris & $\begin{array}{l}\text { Use appropriate technology to remove } \\
\text { waste residues from internal surfaces, } \\
\text { visually verify clean internal surface. }\end{array}$ & $\begin{array}{l}\text { Determine regulatory status } \\
\text { and endpoint }{ }^{2}\end{array}$ \\
\hline Vault $\&$ valve pit piping & $100 \mathrm{ft}$ SS pipe & Contaminated debris & Rinse \& remove waste & Remove \& ship to TSD \\
\hline 340-A piping & $100 \mathrm{ft}$ SS pipe & Contaminated debris & Rinse \& remove waste & Remove \& ship to TSD \\
\hline 340-B piping & $100 \mathrm{ft}$ SS pipe & Contaminated debris & Rinse \& remove waste, reuse for RPS & Remove \& ship to TSD \\
\hline Vault to 340-A primary piping & $25 \mathrm{ft}$ SS pipe & Contaminated debris & $\begin{array}{l}\text { Use appropriate technology to remove } \\
\text { waste residues from internal surfaces, } \\
\text { visually verify clean internal surface. }\end{array}$ & $\begin{array}{l}\text { Determine regulatory status } \\
\text { and endpoint }{ }^{2}\end{array}$ \\
\hline Vault to $340-B$ primary piping & $100 \mathrm{ft}$ SS pipe & Contaminated debris & $\begin{array}{l}\text { Use appropriate technology to remove } \\
\text { waste residues from internal surfaces, } \\
\text { visually verify clean internal surface. }\end{array}$ & $\begin{array}{l}\text { Determine regulatory status } \\
\text { and endpoint }{ }^{2}\end{array}$ \\
\hline $\begin{array}{l}\text { Decon sump drain to valve-box } 9 \\
\text { primary piping }\end{array}$ & $25 \mathrm{ft}$ SS pipe & Contaminated debris & $\begin{array}{l}\text { Use appropriate technology to remove } \\
\text { waste residues from internal surfaces, } \\
\text { visually verify clean internal surface. }\end{array}$ & $\begin{array}{l}\text { Determine regulatory status } \\
\text { and endpoint }{ }^{2}\end{array}$ \\
\hline \multicolumn{5}{|l|}{ Dangerous Waste Tanks } \\
\hline Vault tanks & $2-15,000$ gal. SS tanks & Contaminated debris & Rinse, minimize heels & Remove \& ship to TSD \\
\hline AGS tanks & $6-8,000$ gal. SS tanks & Contaminated debris & $\begin{array}{l}\text { Use appropriate technology to remove } \\
\text { waste residues from internal surfaces, } \\
\text { visually verify clean internal surface. }\end{array}$ & $\begin{array}{l}\text { Determine regulatory status } \\
\text { and endpoint } 2\end{array}$ \\
\hline \multicolumn{5}{|l|}{ Ancillany Equipment } \\
\hline Vault tank sampling lines & $100 \mathrm{ft} 1 / 2^{n}$ SS pipe & Contaminated debris & $\begin{array}{l}\text { Rinse to remove waste, remove } \\
\text { accessible portions \& send to TSD }\end{array}$ & $\begin{array}{l}\text { Remove inaccessible portions } \\
\text { \& ship to TSD }\end{array}$ \\
\hline Decon sample hood drain & SS 2"drain line & Contaminated debris & Rinse \& remove waste & Remove \& ship to TSD \\
\hline Decon sump & SS sump liner & Contaminated debris & Remove \& send to TSD & (Removed in Phase I) \\
\hline Decon sump pump & 1 pump & Contaminated debris & Remove \& send to TSD & (Removed in Phase I) \\
\hline Pumps/valves in valve pit $\&$ vault & 5 pumps and 23 valives & Contaminated debris & Rinse \& remove waste & Remove \& ship to TSD \\
\hline
\end{tabular}




\begin{tabular}{|c|c|c|c|c|}
\hline $\begin{array}{l}\text { TankSystem } \\
\text { Component }\end{array}$ & $\begin{array}{l}\text { Estimated Quantity/ } \\
\text { Description }\end{array}$ & Regulatory Status & Proposed phase I Action & $\begin{array}{c}\text { Proposed Phase II } \\
\text { Action }\end{array}$ \\
\hline \multicolumn{5}{|l|}{ Secondary Containment } \\
\hline RLWS secondary piping & 2,370 ft FRP pipe & $\begin{array}{l}\text { Potential contaminated } \\
\text { debris }\end{array}$ & Document integrity / status & $\begin{array}{l}\text { Determine regulatory status } \\
\text { and endpoint }{ }^{2}\end{array}$ \\
\hline 329 to VB1 secondary piping & $150 \mathrm{ft} \mathrm{FRP} \mathrm{pipe}$ & $\begin{array}{l}\text { Potential contaminated } \\
\text { debris }\end{array}$ & Document integrity / status & $\begin{array}{l}\text { Determine regulatory status } \\
\text { and endpoint }{ }^{2}\end{array}$ \\
\hline Vault to $340-A$ secondary piping & $50 \mathrm{ft}$ FRP pipe & $\begin{array}{l}\text { Potential contaminated } \\
\text { debris }\end{array}$ & Document integrity / status & $\begin{array}{l}\text { Determine regulatory status } \\
\text { and endpoint }{ }^{2}\end{array}$ \\
\hline Vault to $340-B$ secondary piping & $100 \mathrm{ft} \mathrm{FRP} \mathrm{pipe}$ & $\begin{array}{l}\text { Potential contaminated } \\
\text { debris }\end{array}$ & Document integrity / status & $\begin{array}{l}\text { Determine regulatory status } \\
\text { and endpoint }{ }^{2}\end{array}$ \\
\hline Valve boxes & $\begin{array}{l}15 \text { coated concrete } \\
\text { structures }\end{array}$ & $\begin{array}{l}\begin{array}{l}\text { Potential contaminated } \\
\text { structure }\end{array} \\
\end{array}$ & Document integrity / status & $\begin{array}{l}\text { Determine regulatory status } \\
\text { and endpoint }{ }^{2}\end{array}$ \\
\hline Decon sump secondary containment & Coated concrete structure & $\begin{array}{l}\text { Potential contaminated } \\
\text { structure }\end{array}$ & Document integrity / status & $\begin{array}{l}\text { Determine regulatory status } \\
\text { and endpoint }{ }^{2}\end{array}$ \\
\hline $\begin{array}{l}\text { Decon sump to valve-box } 9 \\
\text { secondary piping }\end{array}$ & $25 \mathrm{ft}$ FRP pipe & $\begin{array}{l}\text { Potential contaminated } \\
\text { structure }\end{array}$ & Document integrity / status & $\begin{array}{l}\text { Determine regulatory status } \\
\text { and endpoint }{ }^{2}\end{array}$ \\
\hline Valve pit & Coated concrete structure & $\begin{array}{l}\text { Potential contaminated } \\
\text { structure }\end{array}$ & Rinse & $\begin{array}{l}\text { Determine regulatory status } \\
\text { and endpoint }{ }^{2}\end{array}$ \\
\hline Vault & Coated concrete structure & $\begin{array}{l}\text { Potential contaminated } \\
\text { structure }\end{array}$ & Rinse & $\begin{array}{l}\text { Determine regulatory status } \\
\text { and endpoint }{ }^{2}\end{array}$ \\
\hline $340-A$ floor \& sump & Concrete structure & $\begin{array}{l}\text { Potential contaminated } \\
\text { structure }\end{array}$ & Rinse & $\begin{array}{l}\text { Determine regulatory status } \\
\text { and endpoint }{ }^{2}\end{array}$ \\
\hline 340-B floor \& sump & Coated concrete structure & $\begin{array}{l}\text { Potential contaminated } \\
\text { structure }\end{array}$ & Rinse & $\begin{array}{l}\text { Determine regulatory status } \\
\text { and endpoint }{ }^{2}\end{array}$ \\
\hline $340-B$ valve pit & Coated concrete structure & $\begin{array}{l}\text { Potential contaminated } \\
\text { structure }\end{array}$ & Rinse & $\begin{array}{l}\text { Determine regulatory status } \\
\text { and endpoint }{ }^{2}\end{array}$ \\
\hline
\end{tabular}

${ }^{1}$ Expected waste category when component/structure becomes a solid waste. Items labeled "contaminated debris" are known to be contaminated with dangerous waste residues and will be removed or decontaminated during the closure process. Items labeled "Potential contaminated debris/structure" are components/structures that could have been contaminated with dangerous waste residues due to their function in the tank system. Although there is a high degree of confidence these components are not contaminated with dangerous waste, their status is not well documented.

${ }^{2}$ After completion of planned waste residue removal activities in the facility, the regulatory status of these components/structures will be determined and the actions required to achieve RCRA closure documented. (See Phase I Tasks, 1.12 through 1.15.) 
- Safety and ALARA issues related to intrusive activities that have the potential of releasing or spreading existing contamination. Excavations would be performed twice in the same area if the RLWS piping is removed separately. Also, any major digging in the 300 Area will require an Environmental Assessment under NEPA to address cultural resource concerns. At a minimum this represents a five-month, $\$ 30,000$ effort.

- The RPS divert signals from the generator facilities are currently relayed to the 340 Complex via telephone lines. In order to make this system more reliable (once the RPS is decoupled from RLWS, and diversions occur at 307. versus at the generator facilities), divert signals from the generator facilities will be hardwired to the 3707-F Building. In order to accomplish this task (Phase I, 2.1) in a cost effective manner, existing RLWS alarm signal wiring (which is buried along side the RLWS piping, and no longer needed once inactivated) will be used. Removal of the RLWS piping would disturb this electrical conduit.

\section{PHASE I Closure-Related ${ }^{3}$ Activities}

- RLWS Piping

Remove dangerous waste contamination from interior surfaces of all RLWS doublewall piping (i.e., both between the generating facilities and the Vault, and within the 340 Complex such as between the Vault and 340-A, 340-B, and 340 Decon Area sump) with a high pressure spray wash system using appropriate cleaning solutions. The piping may then be rinsed, and the rinsate sampled and analyzed ${ }^{4}$ prior to disposal. All cleaning and rinse solutions will be disposed of according to the results of designation per WAC 173-303-070(3)(a) and WAC 173-303-070(5), as newlygenerated waste (WAC 173-303). The interior surfaces of the piping will then be visually inspected with a remote video camera inserted into the system clean outs, or other access points as needed and as available to verify all dangerous waste contamination has been removed.

Document status of RLWS piping secondary containment to verify system integrity. This is envisioned as a review of the installation project files, historical valve box leak detection alarm incidents, and routine surveillance records. Decontaminate and dispose of waste residues as newly-generated wastes.

${ }^{3}$ It is understood that upon completion of the activities identified in this subsection and the Phase II subsection (themselves subject to regulator acceptance), final "closure" may remain to be completed.

${ }^{4}$ Although not required for debris rule verification, sampling is required prior to waste shipment and it could provide added assurance that radioactive contamination is either fixed or gone, and can aid in completing a waste designation for the rinsate. This is good ALARA practice for subsequent camera work and capping and will be useful ERC turnover information. 
- Tanks

340-A Tanks - After tank heels (if any) are removed, remove dangerous waste contamination from interior surfaces of tanks and piping by cleaning to meet performance standards of the Debris Rule. Rinse tanks and piping after cleaning and sample rinsate as sound ALARA practice and useful turnover information. Dispose of all cleaning solutions as newly-generated waste under the appropriate designation category. Verify clean with visual inspection. Isolate and blank all tank penetrations and remove associated piping for disposal, all without disabling the ability to function as a tank. Leave tanks in place for Phase II transition to ERC.

340 Vault Tanks - Rinse and minimize heels in the two tanks. These Vault tanks will be used to collect flush and rinse solutions during Phase I activities.

- Ancillary Equipment

The Vault tank sample lines will be rinsed for ALARA and waste designation purposes. Accessible portions within Decon Area will be removed and shipped to a TSD facility for treatment and disposal.

Portions of the 340 Decon Area hood drainage line will be removed and shipped to a TSD for treatment and disposal. The hood will be decontaminated and placed in standby condition for potential future use, such as sample preparation in the event of an RPS divert to the 307 Basins.

The 340 Decon Area sump pump, discharge line, and sump liner will be removed and shipped to a TSD facility for treatment and disposal. The sump annulus will be visually inspected and decontaminated, if needed. The annulus endpoint and regulatory status will be determined in Phase II.

At the completion of Phase I activities, components of the RLWS system will have either met closure conditions, been stabilized and waiting closure, or have been removed and shipped to a TSD facility.

\section{PHASE II Closure-Related Activities}

Phase II activities involve the goal of meeting final closure requirements for the RLWS system, structures and components, and completing endpoint documentation for transition to the ERC. Whether or not final closure can be achieved prior to transition will be a function of the effectiveness of planned cleanup activities and the related negotiations with regulators.

- RLWS Piping

The RLWS piping and associated valve boxes will be left in place for either demolition or remediation (depending upon closure status) during 300-FF-2 operable unit CERCLA cleanup operations. The Vault and Valve Pit piping will be removed and 
shipped to a TSD facility for treatment and disposal. RLWS associated piping in the 340-A and 340-B Buildings will be removed and shipped to a TSD facility for treatment and disposal.

- Tanks

If the six 340-A tanks meet the alternate debris standards after cleaning, they will be left in place and transitioned to the ERC for either demolition and disposal as nondangerous waste or for re-use. The two Vault tanks will be removed and shipped to a TSD facility for treatment and disposal.

\subsection{Tri-Party Agreement Milestones}

Additional milestones for the 300 Area were developed during 1996 and issued in the Tri-Party Agreement in June 14, 1996 (Ecology et al. 1996). The milestones addressing the 340 Complex are contained in M-92-00 and its supplements and govern the disposition of 300 Area special case waste (SCW). Removal and transfer of 300 Area SCW will be completed in a separate three-phase approach for which the milestones are:

Milestone M-92-13 - Submit 300 Area SCW PMP to Ecology pursuant to Agreement Action Plan Section 11.5 by September 2000.

Milestone M-92-14 - Complete removal and transfer, and initiate storage of Phase I $300 \mathrm{SCW}$ and materials by September 2002 . Phase I inventory will consist of, at minimum, one-third the total curie content of all $300 \mathrm{SCW}$.

Milestone M-92-15 - Complete removal and transfer, and initiate storage of Phase II $300 \mathrm{SCW}$ waste and materials by September 2004 . Phase II inventory will consist of, at minimum, one-half of the remaining curie content of all $300 \mathrm{SCW}$ and materials.

Milestone M-92-16 - Complete removal and transfer, and initiate storage of Phase III $300 \mathrm{SCW}$ waste and materials by September 2006 . Phase III inventory will consist of any remaining $300 \mathrm{SCW}$ and materials.

The 340 Complex wastes included in SCW are the sludges in the AGS and Vault tanks. A separate SCW PMP for the 300 Area is being developed by BWHC to meet the M-92-13 milestone. That document will determine where the 340 Complex SCW clean out occurs within the three-phased process.

The milestones form the basis for the 340 Complex transition work and are consistent with early assumptions and endpoints developed for the 340 Complex transition. There are no TSD units at the 340 Complex, therefore, there are no plans to develop additional milestones in the Tri-Party Agreement for the transition of the Complex. 


\subsection{Clean Air Act Status and Strategy}

It is the policy of the DOE and WMH to conduct effluent monitoring that is adequate to determine whether the public and environment are protected during DOE nuclear site operations and whether those operations are in compliance with DOE and other applicable federal, state, and local radiation standards and requirements. The policy, purpose and scope of the 340 Complex airborne emissions measurement and monitoring program are contained in WHC-EP-0469-2, Facility Effluent Monitoring Plan for the 340 Waste Handling Facility (WHC 1996b).

All new activities, construction, and/or modifications at the 340 Complex that have the potential for increasing air emissions or introducing new pollutant emissions will be evaluated for the need to submit a NOC application to appropriate agencies, i.e., EPA, $\mathrm{DOH}$, and/or Ecology. The following NOCs pertain to the 340 Complex:

- DOE/RL-96-75, Annual Update to Notice of Construction for Portable Temporary Radioactive Airborne Emissions Units, February 1995,

- As conditionally approved by DOH for the annually updated DOE/RL-96-75, Rev. 1, State of Washington, Department of Health, Radioactive Air Emissions Notice of Construction for Portable/Temporary Radioactive Air Emission Units in a letter from A.W. Conklin to J.E. Rasmussen (RL), AIR 97-1207, dated December 15, 1997 (DOE-RL 1995a);

- DOE/RL-97-15, Nonradioactive Air Emissions Notice of Construction for Removal of 340A Building Tank Solids, February 1997,

- As approved by Ecology (WAC 173-400 and WAC 173-460) in a letter from M.A. Crane to J.E. Rasmussen (RL), dated May 5, 1997, (DOE-RL 1997a); and

- DOE/RL-97-06, Rev. 0, Radioactive Air Emissions Notice of Construction 340-A Building Tank Sludge Clean Out, April 1997,

- As approved by EPA (40 CFR 61) in a letter from A.J. Frankel to J.E. Rasmussen $(R L)$, dated July 17,1997 , and

- As approved by DOH (WAC 246-247) in a letter from A.W. Conklin to J. E. Rasmussen (RL), AIR 97-604, dated June 6, 1997 (DOE-RL 1997b).

The 340 Complex has three point source radioactive airborne emission units that have a potential for regulated releases. These emission points are: Tank vent system, $\mathrm{K} 1$, exhaust 340-NT-EX; 340-B East ventilation stack, 340-B-Building, K2, system; and 340 Building facility stack, 340-Decon, K3, system. 


\subsubsection{Tank Vent System Exhaust, 340-NT-EX, K1}

The 340 tank vent exhaust system, $\mathrm{K} 1$, provides air ventilation to the 340 Vault and Valve Pit, 340 Vault tanks, and the 340-A Building tanks. Pursuant to 40 CFR 61.93, $\mathrm{K} 1$, a major stack, is subject to continuous emissions measurement requirements. Phase I cleanout and deactivation activities may need to be evaluated for possible NOC filings. The K1 stack will be downgraded to an air emissions unit subject to 40 CFR 61.93 periodic confirmatory measurement requirements, referred to as a minor stack at the completion of measures taken during Phase I. These measures include cleaning and/or containing residual contamination, and sealing of tank penetrations. The need for the continued operation of the K1 as a minor stack awaits an evaluation of the effectiveness of Phase I actions. Possible mothballing of the filtration exhaust system for use during Phase II tank removal and vault decontamination work will be considered, although this PMP will schedule their removal under Phase I. Prior to performing this action, it must first be verified that shutting down the emissions unit will not violate WAC 246-247-040(4) requirements for as low as reasonable achievable control technology (ALARACT) (WAC 246-247).

Upon shutting down the emissions unit, a report of closure will be filed with the $\mathrm{DOH}$ pursuant to WAC 246-247-080(6). Furthermore, the Hanford Site Air Operating Permit $(A O P)$ may require removal of the emissions unit from the $A O P$.

\subsubsection{0-B East Ventilation Stack, 340-B-Building, K2}

The 340-B ventilation stack exhaust system, $\mathrm{K} 2$, provides air ventilation to the east section of the $340-B$ Building. This ventilation system is operated only when a rail car is being connected or disconnected to facility piping and during the associated waste transfers. K2 is a minor stack, i.e., an air emissions unit subject to 40 CFR 61.93 periodic confirmatory measurement requirements, and will be kept in serviceable operating condition for waste transfers until no longer needed. The K2 stack will likely be removed from service during Phase II transition activities when RPS operations are terminated. Prior to performing this action, it must first be verified that shutting down the emissions unit will not violate WAC 246-247 ALARACT requirements.

Upon shutting down the emissions unit a report of closure will be filed with the $\mathrm{DOH}$ pursuant to WAC 246-247-080(6). Furthermore, the AOP may require removal of the emissions unit from the AOP.

\subsubsection{Building Stack, 340-Decon, K3}

The 340 Building stack exhaust system, $\mathrm{K} 3$, provides air ventilation to the truck lock, operator's office, change-rooms, decontamination area, and sampling hood. The K3 stack will remain in operation during Phase I transition activities and will be shutdown during Phase II transition activities when no longer needed. Prior to performing this action, it must first be verified that shutting down the emissions unit will not violate WAC 246-247 ALARACT requirements. 
HNF-2230 Rev. 0

Upon shutting down the emissions unit a report of closure will be filed with the $\mathrm{DOH}$ pursuant to WAC 246-247-080(6). Furthermore, the AOP may require removal of the emissions unit from the AOP.

\subsection{Clean Water Act and Safe Drinking Water Act Status and Strategy}

Currently, two primary liquid effluents are discharged from the 340 Complex:

Process sewer - The process sewer receives cooling water, process water and other non-sanitary liquid effluent. The process sewer line from the 340 Complex ties into a line in common with other facilities where the effluent flows to the TEDF. At TEDF the effluent is treated prior to discharge to the Columbia River. There are two storm drains within the 340 Complex fence line. One drains to the 307 Basins, and the other drains to the process sewer.

Sanitary sewer - The sanitary sewer receives sanitary liquid wastes from kitchens and restrooms. The sanitary sewer lines from the 340 Complex tie into a common line with other facilities and the effluent flows to the City of Richland Publicly Owned Treatment Works.

During deactivation, the above effluent streams (except for the storm drains) from the Complex will be eliminated, lines blanked, and drains plugged.

\subsection{National Environmental Policy Act (NEPA) and State Environmental Policy Act (SEPA) and Endangered Species Act (ESA) Status and Strategy}

NEPA coverage of proposed deactivation activities at the 340 Complex is contained in 97-STO-091, Categorical Exclusion for the 325 and 340 Facilities Radioactive Liquid Waste System Modifications (DOE-RL/NEPA 1997).

The above referenced categorical exclusion (CX) approval document addresses deactivation of portions of the 340 Facility. The document was approved by the DOERL NEPA Compliance Officer and provides the NEPA documentation for the action. The applicable section of the document concerning 340 Complex deactivation is presented verbatim below:

\section{Facility Deactivation}

Portions of the 340 Complex that manage the receipt and storage of RLW would be deactivated. Current deactivation plans address the below-grade concrete Vault containing two stainless steel tanks, the 340-A Building (with six above ground storage tanks), and the east side of the 340-B (used for rail tanker load-out). Other portions of the 340 Complex will continue to support ongoing missions, i.e., the retention process sewer, the 307 Basins, and the west side of 340-B (used for solid waste staging). 'The 307 Basins would be maintained to provide containment capacity in the event of retention process sewer diversions and other emergency situations in 300 Area facilities. The railroad which currently senves the 340 
Complex and provides RLW shipment to the 200 East Area is expected to cease operations within the next several years.

Current planning scope indicates that the 340 Facility deactivation would include activities such as the following:

- The radioactive and hazardous inventory would be removed.

- Radioactive or hazardous contamination would be removed, reduced, or isolated from facilities and equipment by washing, heating, chemical or electrochemical action, mechanical cleaning, or other techniques.

- Any loose asbestos would be removed.

- A truck load-out station or other form of valved access station would be installed at or near the 307 Basins by refurbishing the 340-B Building or constructing a modular structure adjacent to the 340 Complex.

- Facility utility and network service systems, such as water supply, fire protection, heating, ventilating and air conditioning systems, electrical service, and lighting, would be removed or minimized, consistent with environmental protection and safety requirements.

- Alternate environmental monitoring and safety components would be installed, if required.

- Adequate freeze and heat protection would be ensured.

- Deactivation activities, such as final process runs, flushing process piping systems, and other closeout actions, would be conducted.

- Piping systems would be drained and lines would be blanked off.

- Equipment would be mothballed, re-used, disposed, or "excessed in place."

A site-wide categorical exclusion (SWCX) also exists titled Deactivation, DeEnergization, or /solation of Unneeded Plant Systems and Stabilization in Hanford Facilities, which also covers many of the same type activities as listed in the previous CX (NEPA 1996). Associated guidance states that "Because of the complexity of deactivation activities, a NEPA Services representative should be consulted when using this SWCX."

Current planning for Phase II deactivation calls for removal of the two Vault tank (and possibly the AGS tanks and RLWS piping and valve boxes) and transporting them to an approved TSD for treatment and disposal. Such activities may be beyond the scope of the activities covered under either CX document, 97-STO-091 or the above noted SWCX (DOE-RL/NEPA 1997 and NEPA 1996). Should this be the case, additional NEPA documentation requirements will be evaluated and planned prior to the initiation of Phase II work.

\section{Cultural Resources, Biological Review and Historical Preservation}

A cultural resource review and a biological review for a proposed 340 Complex project were completed by Hanford Cultural Resources Laboratory (HCRL) and documented as HCRC No. 95-300-017, Cultural Resources Review of Project W-302, 340 Facility Containment and Leak Detection and Biological Review of the W-302, 340 Facility Containment and Leak Detection (HCRL 1994a and HCRL 1994b). Discussions with HCRL staff indicate that both a cultural resource review and biological review will still be required for deactivation work, prior to any excavations. Therefore, Phase II deactivation activities will need to be evaluated to determine when and if these required 
HNF-2230 Rev. 0

reviews and associated documentation need to be completed.

The required historical documentation per the National Historic Preservation Act (NHPA) for the 340 Complex has been completed. However, prior to any building modification or excavation, a walk-though of the Complex by qualified historical professional(s) is required to determine if historical artifacts are present. If they are present and are not contaminated, or can be decontaminated, they will be removed and placed in suitable storage as historical artifacts. 
HNF-2230 Rev. 0

This page intentionally without substantive content. 
HNF-2230 Rev. 0

\subsection{DEACTIVATION PROJECT INTEGRATED SAFETY STRATEGY}

The following discussion identifies the process that will be used by the 340 Complex transition project to ensure that the safety of the worker, public and the environment are adequately addressed during transition tasks and operations. The primary activities involved in this process include the following:

- Use the DOE-approved authorization basis and the USQ process to determine if transition activities are within the defined safety envelope and, if not, to obtain the appropriate authorization;

- Identify, control, or mitigate worker safety related issues for deactivation activities; and

- Provide the required safety documentation for the surveillance and maintenance period.

\subsection{Safety Evaluation of Activities}

A key element for safety during the transition project is the adequate evaluation of planned activities to determine the potential impacts to the workers, public, and the environment. To accomplish this objective, the safety basis for the project must be established and a graded hazards screening and assessment process will be implemented in conjunction with the USQ process. Figure 10-1 illustrates the path for USQ screening and hazards assessment planning.

\subsubsection{Safety Basis Documentation}

The safety basis for the transition project is defined in WHC-SD-WM-ISB-003, Rev. 0 , 340 Waste Handling Facility Interim Safety Basis (WHC 1996c). Consistent with the requirements of DOE Order 5480.21, Unreviewed Safety Question, the 340 Facility authorization basis and associated Safety Evaluation Report (SER), includes the information used in development and approval of the ISB such as references and related documents. These documents will be used in the implementation of the unreviewed safety question process as required by the referenced order. This process and its implementation for the 340 Complex transition project is described further in the following sections.

\subsubsection{Unreviewed Safety Question Process}

The 340 Complex implements a graded approach in conformance with the requirements of DOE 5480.21, Unreviewed Safety Questions, and to HNF-PRO-062, Identifying and Resolving Unreviewed Safety Questions (FDH 1997a). The USQ process for the 340 Complex transition project is implemented in WMH-200, Section 4.3, Rev. 1, Unreviewed Safety Questions, and the administration of the Plant Review Committee (PRC) when a potential USQ is identified (WMH 1998d). 
HNF-2230 Rev. 0

Figure 10-1. USQ Screening and Hazard Assessment Planning.

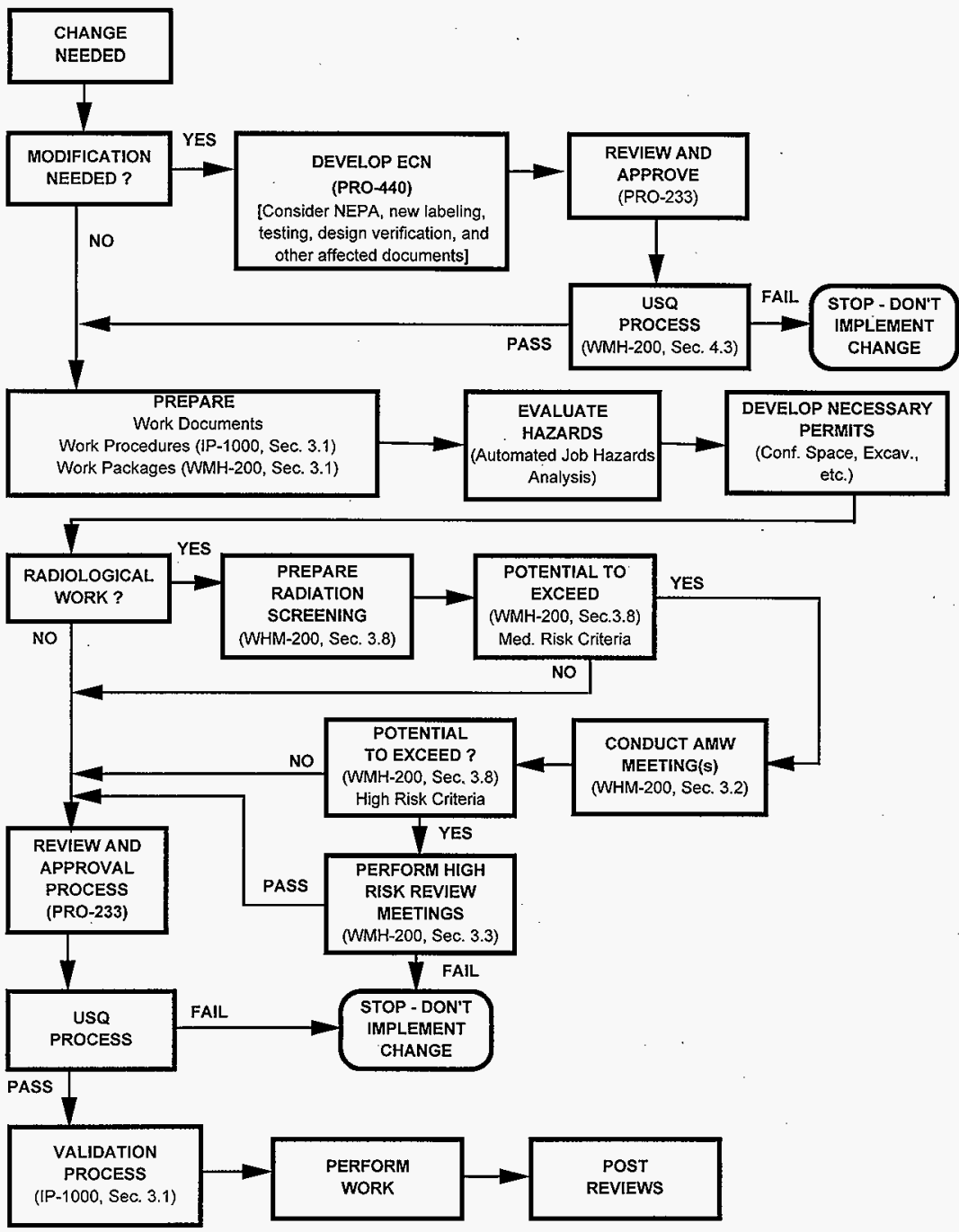


The USQ screening process requires two individuals to evaluate changes. These evaluators, referred to as USQEs, are provided facility specific training. The screening process involves the first USQE performing a USQ screening in accordance with HNFPRO-062 which is then forwarded to the second USQE where it is given an independent review (FDH 1997a). If no potential USQ is identified, the USQ screening documentation is attached to the document and maintained as a part of the document history file and work is permitted to proceed. If a potential USQ is identified, the change must be reviewed against the USQ evaluation criteria.

If the USQ evaluation process is required, the USQEs perform independent USQ evaluations of the change or discovery. The USQ evaluations of discoveries should be completed within $48 \mathrm{hr}$ from the time the occurrence was reported to management. If the evaluation indicates a potential USQ exists, the PRC secretary is notified to set up a formal meeting of the PRC.

The PRC consists of the facility manager, the engineering manager and the facility safety representative. Depending on the issues, others such as the QA and health physics representatives may be invited to attend a particular meeting. A meeting of the PRC is scheduled as soon as possible after a potential USQ is identified. The PRC shall review the independent evaluations conducted by the USQEs. Unanimous agreement from the voting members is required to declare a non-USQ. If a USQ is declared against an existing condition, the facility must be immediately placed in a safe condition. A Justification for Continued Operations $(\mathrm{JCO})$ is prepared in accordance with HNF-PRO-062 (FDH 1997a). DOE-RL will be notified in the event that the declared USQ involved potential inadequacies of the previous analysis as defined in the ISB. A completed safety evaluation will be submitted to DOE-RL for approval prior to removing any operational restrictions initiated as a result of the USQ process. DOE-RL must provide approval documentation prior to initiating changes to the facility regarding a USQ.

\subsection{Worker Safety}

In addition to the graded hazards assessment process described above, all transition tasks will be screened and evaluated regarding worker hazards, nuclear safety hazards and potential environmental hazards. This process, the Automated Job Hazards Analysis (AJHA), will be utilized to ensure that worker hazards are identified, communicated to the workers, and the proper controls are incorporated into the work activity to prevent, mitigate and control the hazards.

This process will be used in addition to the current company-wide worker safety programs and their requirements. The use of the graded task level hazards screening and analysis process combined with these other programs will provide an effective means of ensuring worker safety during the completion of the transition projects. When finalized, guidance from the draft DOE-STD-XXXX-97, Integration of Safety and Health into Facility Disposition Activities, will be factored into this process as appropriate (DOE 1997). 
HNF-2230 Rev. 0

\subsubsection{Radiological Screening}

The primary hazard associated with work at the 340 Complex involves radiological concerns. The facility utilizes a radiological work screening to determine the level of oversite and/or controls needed for the work. The radiological screen involves the following questions:

- Is the proposed work an infrequent or first time activity?

- Will any radioactive systems be breached?

- What is the radiological history of the system?

- What is the radiological history of similar work and are there any lessons learned?

- How much radioactive waste will be generated? What will be its physical form? Will mixed waste be generated?

- What are the initial radiological conditions and what conditions will be created by the work? One must consider airborne radioactivities; whole body and extremity beta and gamma dose rates; alpha, beta-gamma surface contamination and the form of contamination.

- Will the work involve cutting, drilling, grinding or welding on potentially contaminated surfaces?

- Are there any surfaces that will be disturbed that have painted contamination?

- Based on radiological data collected or assumed, will any ALARA trigger levels be reached?

- What engineered controls can be used to mitigate the radiation and/or contamination levels and minimize the waste created?

The information gathered by these questions will be used to assess the job risk and determine RWP requirements. Based on the screening process and input from the Radiological Control group each task is evaluated against trigger levels provided defined in WMH-200, Section 2.8 (WMH 1998d). These trigger levels define a task as low risk, medium risk or high risk. The level of oversight is dependent on the risk level.

\subsubsection{Risk Based Radiological Planning}

ALARA planning should be done at all three risk levels. However, the difference in planning between the risk levels is the relative benefit associated with the cost of the planning effort. At lower risk levels the benefit may not justify very much effort or cost. However, it is also important to look at the long-term radiological risk of work that will be performed routinely. For example, a single job may not warrant exposure reduction because it only saves a few person-mrem, or cleans up a small amount of contamination. However, if the job is to be repeated or other jobs will be performed in the same area, the collective exposure saved or contamination buildup prevented during several low risk jobs may warrant the application of added shielding or contamination controls.

\section{Low Risk Planning}

Planning for low risk radiological work need only be informal and can be performed in 
HNF-2230 Rev. 0

conjunction with preparing the RWP for the job or reviewing existing RWPs to determine if they are suitable for the task to be performed.

\section{Medium Risk Planning}

Planning for medium risk, radiological work requires more involvement of facility Radiological Control personnel. An ALARA Management Worksheet is developed to ensure adequate consideration and controls are applied.

\section{High Risk Planning}

Tasks with the potential to exceed the high risk trigger levels undergo a formal, documented high risk work review per WMH-200, Section 3.3 (WMH 1998d). At a minimum, the work document should consider the following:

- Inclusion of radiological control hold points in the technical work documents,

- Elimination or reduction of radioactivity through line flushing and decontamination,

- Use of work processes and special tooling to reduce time in the work area,

- Use of engineered controls to minimize the spread of contamination and generation of airborne radioactivity,

- Specification of special radiological training or monitoring requirements,

- Use of mockups for high exposure or complex tasks,

- Engineering, design and use of temporary shielding to reduce radiation levels,

- Walk down or dryrun of the activity using applicable procedures,

- Staging and preparation of necessary materials and special tools,

- Maximization of prefabrication and shop work,

- Review of abnormal and emergency procedures and plans,

- Identification of points where signatures and second party or independent verifications are required,

- Establishment of success or completion criteria, with contingency plans to anticipate difficulties,

- Development of a pre-job estimate of collective doses to be incurred for the job, and

- Provisions for waste minimization and disposal.

The steps taken to mitigate radiological hazards should be formally documented using the ALARA Management Worksheet (AMW). The work should have a documented Pre-Job ALARA Review Record and Post-ALARA Review completed by the job supervisor or lead engineer.

Using the graded hazards assessment process, all deactivation tasks will be screened and evaluated regarding worker industrial safety, radiological safety and potential environmental hazards. This process will be utilized to ensure that worker hazards are identified, communicated to the workers, and the proper controls are incorporated into the work activity to prevent, mitigate or control the hazard.

The process described above will be used in addition to the current company-wide worker safety programs and their requirements. The use of the graded task level 
HNF-2230 Rev. 0

hazards screening and analysis process combined with other programs will provide an effective means of ensuring worker safety during the implementation and completion of deactivation activities.

\subsection{Post-Deactivation Safety Documentation}

As one of the conditions for transfer of the 340 Complex to the Hanford Surplus Facilities Program, the safety documentation will be updated to reflect the current facility conditions and controls necessary to prevent or mitigate accident scenarios. The hazard classification for the 340 Complex is expected to be Radiological following completion of transition activities. Based on this classification, the appropriate safety basis documentation for surveillance and maintenance will be developed. The safety basis will be developed near the end of Phase II in accordance with current DOE Orders, standards and other guidance and requirements, and will rely upon the current facility and site safety documentation. The safety basis will be specific to the Complex end-state activities and conditions of the 340 Complex. 
HNF-2230 Rev. 0

\subsection{REFERENCES}

10 CFR 830, "Quality Assurance Requirements," Code of Federal Regulations, as amended.

40 CFR 60, 1989, "Standards of Performance for New Stationary Sources,." Code of Federal Regulations, as amended.

40 CFR 61, 1991, "National Emission Standards for Hazardous Air Pollutants," Code of Federal Regulations, as amended.

40 CFR 261, 1990, "Identification and Listing of Hazardous Waste," Code of Federal Regulations, as amended.

40 CFR 268, 1997, "Land Disposal Restrictions," Code of Federal Regulations, as amended.

40 CFR 761, 1990, "Polychlorinated Biphenyls (PCBs) Manufacturing, Processing, Distribution in Commerce, and Use Prohibitions," Code of Federal Regulations, as amended.

Apley, W.J., 1996, Review and Comments of the 340 Waste Handling Facility Deactivation Plan, Letter 9601973 to A.J. DiLiberto, dated August 6, 1996, Pacific Northwest National Laboratory, Richland, Washington.

Berneski, L.D., 1995, Hanford 300 Area Retention Process Sewer - Inventory at Risk Calculations and Safety Analysis, WHC-SD-WM-SAD-027, Rev. 0, Westinghouse Hanford Company, Richland, Washington.

DOE, 1991, Unreviewed Safety Question, DOE Order 5480.21, U.S. Department of Energy, Washington, D.C.

DOE, 1994, Personnel Selection, Qualification and Training Requirements for DOE Nuclear Facilities, DOE Order 5480.20A, U.S. Department of Energy, Washington, D.C.

DOE, 1995a, Decommissioning Resource Manual, DOE-EM-0246, August 1995, EM-40, Office of Environmental Restoration, U.S. Department of Energy, Washington, D.C.

DOE, 1995b, Facility Deactivation End Points Handbook, Third Draft for Use and for Comment, November 16, 1995, EM-60, Office of Nuclear Material and Facility Stabilization, U.S. Department of Energy, Washington, D.C.

DOE, 1996, Life Cycle Asset Management, DOE Order 430.1A, U.S. Department of Energy, Washington, D.C. 
DOE, 1997, Integration of Safety and Health in to Facility Disposition Activities, Draft DOE-STD-XXXX-97, Department of Energy, Washington, D.C.

DOE-RL, 1995a, Annual Update to Notice of Construction for Portable Temporary Radioactive Airborne Emissions Units, DOE/RL-96-75, U.S. Department of Energy, Richland Operations Office, Richland, Washington, February 1995, as conditionally approved by DOH for the annually updated DOE/RL-96-75, Rev. 1, State of Washington, Department of Health, Radioactive Air Emissions Notice of Construction for Portable/Temporary Radioactive Air Emission Units in a letter from A.W. Conklin to J.E. Rasmussen (RL), AIR 97-1207, December 15, 1997.

DOE-RL, 1995b, Identification of Non-Permitted Treatment, Storage, or Disposal (TSD) Facilities and Related Potential Environmental Non-Compliant Conditions at the Hanford Site, Letter 95-PCA-342 from J.D. Wagoner to D. Silver (Ecology), dated July 6, 1995, with Tracking Nos. 16.1.5, 16.2.5, 16.4.1, 16.5.5, and 25.

DOE-RL, 1996a, Hanford Strategic Plan, DOE/RL-96-92, U.S. Department of Energy, Richland Operations Office, Richland, Washington.

DOE-RL, 1996b, Long-Term Facility Decommissioning Plan, DOE/RL-96-0046, U.S. Department of Energy, Richland Operations Office, Richland, Washington.

DOE-RL, 1997a, Nonradioactive Air Emissions Notice of Construction for Removal of 340A Building Tank Solids, DOE/RL-97-15, U.S. Department of Energy, Richland Operations Office, Richland, Washington, February 1997, as approved by Ecology (WAC 173-400 and WAC 173-460) in a letter from M.A. Crane to J.E. Rasmussen (RL), dated May 5, 1997.

DOE-RL, 1997b, Radioactive Air Emissions Notice of Construction 340-A Building Tank Sludge Clean Out, DOE/RL-97-06, Rev. 0, U.S. Department of Energy, Richland Operations Office, Richland, Washington, April 1997, as approved by EPA (40 CFR 61) in a letter from A.J. Frankel to J.E. Rasmussen (RL), dated July 17, 1997; and, as approved by DOH (WAC 246-247) in a letter from A.W. Conklin to J.E. Rasmussen (RL), AIR 97-604, dated June 19,1997.

DOE-RL/NEPA, 1997, Categorical Exclusion for the 325 and 340 Facilities Radioactive Liquid Waste System Modification, Hanford Site, Richland, Washington, 97-STO-091, April 21, 1997, Department of Energy, Richland Operations Office, National Environmental Policy. Act Compliance, Richland, Washington.

DynCorp, 1998, Hanford Railroad Shutdown Project Plan, prepared by DynCorp Tri-Cities Services, Inc. and transmitted to RL via letter FDH-9760267 R4, dated January 30, 1998.

Ecology, 1994, Guidance for Clean Closure of Dangerous Waste Facilities, August 1994, Washington State Department of Ecology, Olympia, Washington. 
Ecology, EPA, and DOE, 1989, Hanford Federal Facility Agreement and Consent, Order. as amended, Washington State Department of Ecology, U.S. Environmental Protection Agency, and the U.S. Department of Energy, Olympia, Washington.

Ecology, EPA, and DOE, 1996, Hanford Federal Facility Agreement and Consent Order, Sixth Amendment, Attachment 2, Action Plan, Section 8.0, "Facility Decommissioning Process, Washington State Department of Ecology, U.S. Environmental Protection Agency, and the U.S. Department of Energy, Olympia, Washington.

FDH, 1997a, Identifying and Resolving Unreviewed Safety Questions, HNF-PRO-062, July 1, 1997, Project Hanford Procedures, Fluor Daniel Hanford, Inc., Richland, Washington.

FDH, 1997b, Quality Assurance Program Implementation Plan for Nuclear Facilities, HNF-SP-1228, July 1, 1997, Fluor Daniel Hanford, Inc., Richland, Washington.

FDH, 1997c, Review and Approval of Documents, HNF-PRO-233, July 1, 1997, Project Hanford Procedures, Fluor Daniel Hanford, Inc., Richland, Washington.

FDH, 1997d, Facility Deactivation Requirements, HNF-PRO-443, August 18, 1997, Project Hanford Procedures, Fluor Daniel Hanford, Inc., Richland, Washington.

FDH, 1997e, Criticality Safety General Requirements, HNF-PRO-334, September 1, 1997, Project Hanford Procedures, Fluor Daniel Hanford, Inc., Richland, Washington.

FDH, 1997f, Facility Shutdown, Standby, and Transfer, HNF-PRO-1794, October 24, 1997, Project Hanford Procedures, Fluor Daniel Hanford, Inc., Richland, Washington.

FDH, 1997g, Configuration Management Plan, HNF-MP-013, October 31, 1997, Project Hanford Procedures, Fluor Daniel Hanford, Inc., Richland, Washington.

FDH, 1997h, Project Hanford Quality Assurance Program Description, HNF-MP-599, Rev. 1, December 31, 1997, Fluor Daniel Hanford, Inc., Richland, Washington.

FDH, 1998, Cost Estimating, HNF-PRO-585, Project Hanford Procedures, Fluor Daniel Hanford, Inc., Richland, Washington.

Hanford, 1997, Hanford Site Radiological Control Manual, HSRCM-1, Prepared for DOE by the Hanford Contractors.

HCRL, 1994a, Cultural Resources Review of Project W-302, 340 Facility Containment and Leak Detection, HCRC No. 95-300-017, November 17, 1994, Hanford Cultural Resources Laboratory, Richland, Washington. 
HNF-2230 Rev. 0

HCRL, 1994b, Biological Review of the W-302, 340 Facility Containment and Leak Detection, HCRC No. 95-300-017, November 29, 1994, Hanford Cultural Resources Laboratory, Richland, Washington.

Lockheed, 1996, "Operations of the LR56 Radioactive Liquid Cask Transport System at U.S. Department of Energy Sites," American Society of Mechanical Engineers, PVP-Vol. 334, pp. 51-58, prepared by personnel from Lockheed Martin Energy Systems, NUMATEC, Inc., and SGN.

McCoy, R.M., 1993, Structural Assessment of the Roof Deck and Supporting Structure for the Solid Waste Disposal Facility [340, 340-A, 340-B] Buildings, WHC-SD-GN-ER-30030, Westinghouse Hanford Company, June 1993.

NEPA, 1996, Deactivation, De-Energization, or Isolation of Unneeded Plant Systems and Stabilization in Hanford Facilities, Site-Wide Categorical Exclusion, National Environmental Policy Act, Richland, Washington.

Roberts, L.W., 1995, 340 Complex Fire Hazard Analysis, WHC-SD-WM-FHA-011, Rev. 0, Hughes Associates, Inc., Columbia, Maryland, for Westinghouse Hanford Company, Richland, Washington.

RFSH, 1996, 340 Waste Handling Facility Interim Safety Basis, WHC-SD-WM-ISB-003, Rev. 1, October 4, 1996, Rust Federal Services of Hanford Company, Richland, Washington.

WAC 173-303, 1990, "Dangerous Waste Regulations," Washington Administrative Code, as amended.

WAC 246-247, 1997, "ALARACT," Washington Administrative Code, as amended.

Walter, E.J., 1996, 340 Facility Waste Tank System Integrity Assessment Report, WHC-SD-WM-ER-546, Rev. 0, May 15, 1996, Westinghouse Hanford Company, Richland.

WHC, 1992, Past Practices Technical Characterization Study - 300 Area - Hanford Site, WHC-MR-0388, December 1992, Westinghouse Hanford Company, Richland, Washington.

WHC, 1993, Hanford Site. Solid Waste Acceptance Criteria, WHC-EP-0063-4, November 1993, Westinghouse Hanford Company, Richland, Washington (latest change May 1996).

WHC, 1995, Engineering Study: 340 Facility Upgrade; Supporting Project W-302 Facility Secondary Containment and Leak Detection, WHC-SD-LEF-ES-001, November 3, 1995, Westinghouse Hanford Company, Richland, Washington. 
WHC, 1996a, Criticality Safety Evaluation Report for 340 Facility, WHC-SD-SQACSA-20379, Rev. 1, February 15, 1996, Westinghouse Hanford Company, Richland, Washington.

WHC, 1996b, Facility Effluent Monitoring Plan for the 340 Waste Handling Facility, WHC-EP-0469-2, April 1996, Westinghouse Hanford Company, Richland, Washington.

WHC, 1996c, 340 Waste Handling Facility Interim Safety Basis, WHC-SD-WM-ISB-003, August 20, 1996, Westinghouse Hanford Company, Richland.

WHC, 1996d, Quality Assurance Manual, WHC-CM-4-2, Westinghouse Hanford Company, Richland, Washington.

WHC, 1996e, Quality Assurance Program and Implementation Plan, WHC-SP-1131, Westinghouse Hanford Company, Richland, Washington.

WHC, 1996f, 340 Waste Handling Facility Deactivation Plan, HNF-SD-LEF-SSP-001, Rev. 0, August, 1996, Westinghouse Hanford Company, Richland, Washington.

WHC, 1998, Management Control System Hanford, HNF-CM-2-5, partially replaced by HNF-PRO-518 through HNF-PRO-536, Westinghouse Hanford Company, Richland, Washington.

WMH, 1994, 300 Area Liquid Effluent Facilities Administration, HNF-IP-1000, September, 1994, Waste Management Federal Services of Hanford, Richland, WA.

WMH, 1996, 340 Waste Handling Facility Deactivation Plan, HNF-SD-LEF-SSP-001, Rev. 1, Waste Management Federal Services of Hanford, Inc., Richland, Washington.

WMH, 1998a, Baseline Change Control, WMH-MD-018, January 16, 1998, Waste Management Federal Services of Hanford, Inc., Richland, Washington.

WMH, 1998b, Extension of Portions of WHC-CM-4-2, WMH-MD-004, Waste Management Federal Services of Hanford, Inc., Richland, Washington.

WMH, 1998c, Quality. Assurance.Program Plan, HNF-SD-WM-QAPP-036, Rev. 1, Waste Management Federal Services of Hanford, Inc., Richland, Washington.

WMH, 1998d, Waste Management Hanford Procedures, WMH-200, Waste Management Federal Services of Hanford, Inc., Richland, Washington. 
HNF-2230 Rev. 0

This page intentionally without substantive content. 


\section{APPENDIX A - GLOSSARY}

Acceptance Criteria - A generic set of acceptance criteria developed by the U.S. Department of Energy Headquarters (DOE-HQ) for use complex wide as a target for acceptance into the surveillance and maintenance (S\&M) phase of decommissioning. Based on these generic acceptance criteria, facility-specific transition endpoint criteria are developed throughout the transition phase with the intent to establish acceptable final conditions of systems, i.e., tanks, piping, and spaces, i.e., rooms and areas, at the end of the transition phase.

Deactivation - Activities associated with removing facility systems and/or areas from operational service with the intent of being ready for facility transition to either convert the facility for another use or move to permanent shutdown. These activities could include the removal of waste, draining and/or de-energizing of systems, removal of accessible stored radioactive and hazardous materials, and other required actions that will place the facility systems and/or spaces in a safe and stable condition. These activities are usually conducted during the facility transition phase.

Decontamination - The process of removing radioactive and/or hazardous contamination from facilities, equipment, or soils by physical removal, washing, heating, chemical action, mechanical cleaning, or other techniques to achieve a stated objective or end condition.

Environmentally Secure - refer to "Safe and Environmentally Secure Configuration."

Facility, as applied to the Facility Decommissioning Process - A free-standing building, plant, laboratory, or other enclosure and associated buildings and disposal sites under its responsibility that fulfills, or fulfilled, a specific purpose and is owned by or otherwise under the responsibility of the DOE-HQ. This usage differs substantially from that in the Comprehensive Environmental Response, Compensation, and Liability Act (CERCLA) and Resource, Conservation and Recovery Act (RCRA).

Facility Decommissioning Process - The sequential phases for a facility, once a shutdown decision is made by DOE-HQ, beginning with facility transition, through $S \& M$, and final facility disposition.

Facility Disposition Phase - Final period in the life of a facility. This phase occurs when no future use is identified as part of the DOE-HQ facility assessment process and priority is given to proceed with disposition. This phase primarily involves processes to achieve a final end state for the facility, e.g., entombment, and/or dismantlement and site restoration, including closure of any TSD units. Facility disposition may be integrated with cleanup of past-practice units covered under CERCLA Remedial Action or RCRA Corrective Measure Authority. 
Facility Endpoint Criteria, as used during facility transition phase - Facility-specific criteria prepared during facility transition planning to support development of the transition planning documentation, work plans, and ultimately the PMP. Collectively these criteria provide a technical description of the acceptable state of facility components to be achieved at the end of the facility transition phase and are prepared consistent with EM-40 acceptance criteria objectives outlined in the Office of Environmental Management Decommissioning Resource Manual (DOE 1995a). The facility endpoint criteria includes a status of how tanks, piping, rooms/areas, and miscellaneous systems and equipment will be left at the end of the transition phase for a period of S\&M prior to final disposition.

Facility Surveillance and Maintenance (S\&M) Phase - Period in the life of a facility following completion of the transition phase until such time as the facility is dispositioned for other use or facility disposition has commenced. The S\&M program provides direction, management, and performance assessments to be carried out in accordance with an approved S\&M Plan. The S\&M phase ensures that facilities are maintained in a safe and environmentally sound manner until a final disposition occurs. In addition, the S\&M level of effort will be established in the S\&M Plan to minimize the costs of final disposition, i.e., as low as economically achievable, whether the facility is planned by DOE-HQ to be released for alternate use or for dismantlement and site restoration and/or entombment under the facility disposition phase.

Facility Transition Phase - A period of time during which activities necessary to place the subject facility in a safe, stable, and environmentally sound condition suitable for an extended period of S\&M pending final disposition are completed. Facility transition starts with termination of operations, includes the establishment of a S\&M program, and ends with the achievement of facility-specific end point criteria.

Interim Monitoring - Activities conducted during the transition phase of the 340 Complex that insures deactivated facilities and/or buildings remain in a physically safe and environmentally secure condition until implementation of the Surveillance and Maintenance phase. This term was developed to identify WMH responsibilities during extended ownership of the 340 Complex until transition is complete.

Safe and Environmentally Secure Configuration - Ensures adequate containment of contamination; provides physical safety and security controls; maintains the facility in a manner which will minimize potential hazards to the public and workers; maintains selected systems or equipment which will be essential for decommissioning activities in a shutdown but standby or operational mode (if economically justified); and provides a mechanism for the identification and compliance with applicable environmental, safety and health, safeguard, and security requirements.

Shutdown Decision - A formal DOE-HQ documented determination that a facility is surplus (see surplus facility).

Surplus Facility - Any facility or site (including equipment) that has no identified 
HNF-2230 Rev. 0

programmatic use by the operating phase Program Management.

Surveillance and Maintenance - Activities conducted to ensure that a site or facility remains in a physically safe and environmentally secure condition, and includes periodic inspections and monitoring of the property, appropriate contamination control actions, and required maintenance of barriers controling access. This process continues as a best management practice through the facility disposition phase until final disposition is achieved as defined in Section 8.0 of the Tri-Party Agreement. 
HNF-2230 Rev. 0

This page intentionally without substantive content.

A -4 
HNF-2230 Rev. 0

APPENDIX B - WBS COST ESTIMATE WORKSHEETS

\begin{tabular}{|c|c|c|}
\hline \multicolumn{3}{|c|}{ Phase I Cost Summary } \\
\hline Task No. & Task Description & Total Dollars \\
\hline 1.0 & Administrative/Engineering Documentation & 205,000 \\
\hline 2.0 & RLWS Isolation \& Piping Decon/RPS Decoupling & 796,000 \\
\hline 3.0 & 340 Building Decon Area Deactivation & 105,000 \\
\hline 4.0 & 340-B East Building Stabilization \& Modification & 137,000 \\
\hline 5.0 & 340-A Building Deactivation & 252,000 \\
\hline 6.0 & 340 Building Vault Decontamination and Isolation & 308,000 \\
\hline 7.0 & Sample and Ship Decontamination Solutions & 514,000 \\
\hline & Subtotal (overheads included) & $\$ 2,320,000$ \\
\hline & Contingency $(30 \%)$ & 684,000 \\
\hline & Total (non-escalated 1998) & $\$ 3,000,000$ \\
\hline
\end{tabular}

Supporting, detailed work sheets follow for Phase I tasks. A Phase II cost summary table in turn follows these Phase I work sheets. 
HNF-2230 Rev. 0

Phase I WBS Cost Estimate Work Sheets

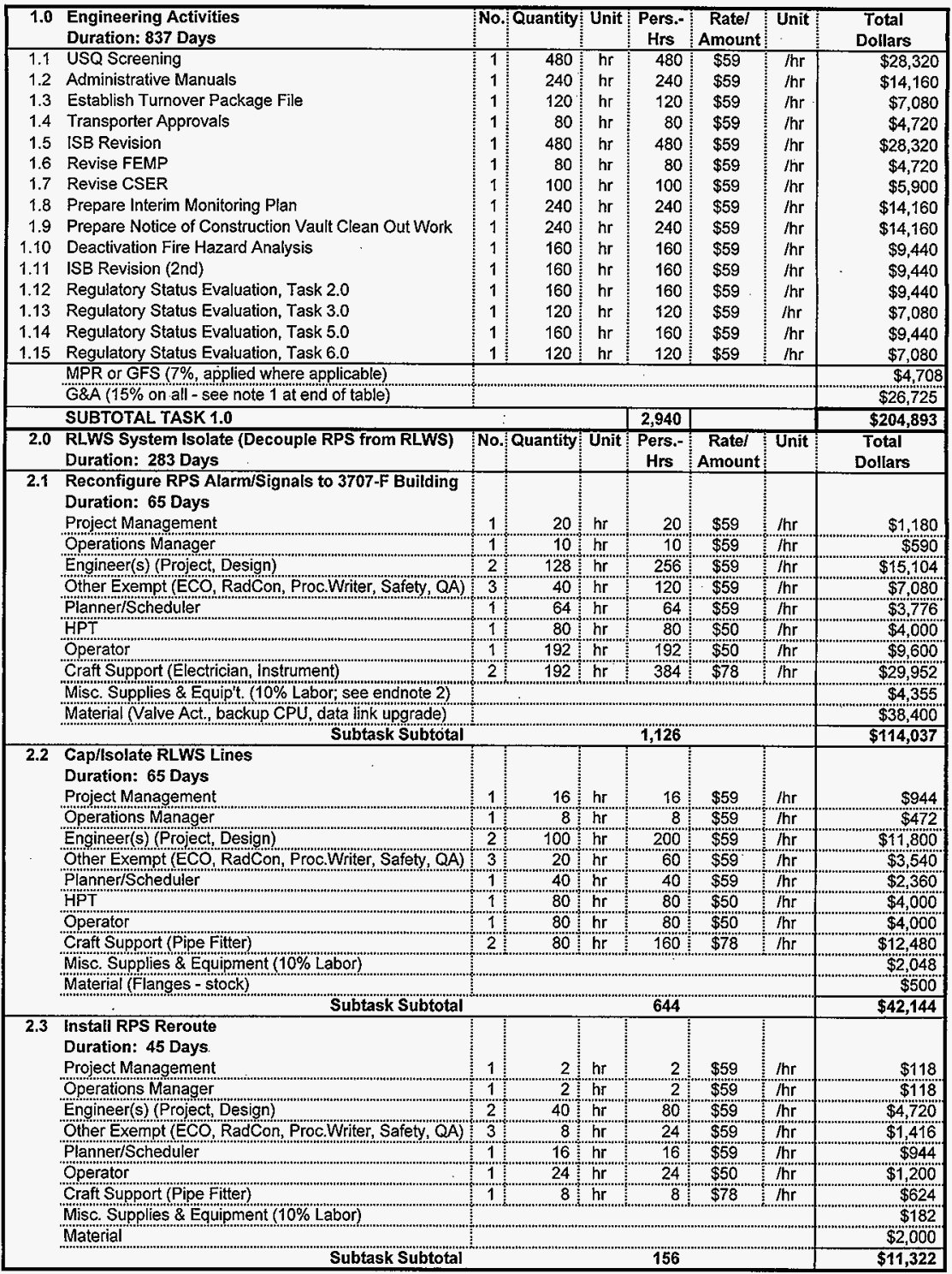


HNF-2230 Rev. 0

Phase I WBS Cost Estimate Work Sheets

\begin{tabular}{|c|c|c|c|c|c|c|c|c|}
\hline $\mathbf{2 . 0}$ & $\begin{array}{l}\text { RLWS System Isolate (Decouple RPS from RLWS) } \\
\text { Duration: } 283 \text { Days }\end{array}$ & No. & Quantity & Unit & $\begin{array}{l}\text { Pers.- } \\
\text { Hrs }\end{array}$ & $\begin{array}{c}\text { Rate/ } \\
\text { Amount }\end{array}$ & Unit & $\begin{array}{l}\text { Total } \\
\text { Dollars }\end{array}$ \\
\hline \multirow[t]{13}{*}{2.4} & $\begin{array}{l}\text { Decontaminate RLWS Piping } \\
\text { Duration: } 64 \text { Days } \\
\text { Project Management }\end{array}$ & 1 & 80 & $\mathrm{hr}$ & 80 & $\$ 59$ & $/ \mathrm{hr}$ & $\$ 4,720$ \\
\hline & Operations Manager & 1 & 48 & $\mathrm{hr}$ & 48 & $\$ 59$ & hinr & $\$ 2,832$ \\
\hline & Engineer(s) (Project) & 1 & 512 & $\mathrm{hr}$ & 512 & $\$ 59$ & hr & $\$ 30,208$ \\
\hline & Other Exempt (ECO, RadCon, Proc. Writer, Safety, QA) & 3 & 96 & $\mathrm{hr}$ & 288 & $\$ 59$ & thr & $\$ 16,992$ \\
\hline & Planner/Scheduler & 1 & 240 & $\mathrm{hr}$ & 240 & $\$ 59$ & "Thr & $\$ 14,160$ \\
\hline & HPT & 2 & 512 & $\mathrm{hr}$ & 1,024 & $\$ 50$ & har & $\$ 51,200$ \\
\hline & Operator & 2 & 512 & $\mathrm{hr}$ & 1.024 & $\$ 50$ & thr & $\$ 51,200$ \\
\hline & Craft Support (Pipe Fitter) & 1 & 176 & $\mathrm{hr}$ & 176 & $\$ 78$ & "The & $\$ 13,728$ \\
\hline & Miso Supplies \& Equipment (10\% Labor) & & & & & & & $\$ 11,613$ \\
\hline & Decon Equipment (Purchase) & & & & & & & $\$ 6,500$ \\
\hline & Sample & & 2 & $\mathrm{ea}$ & & $\$ 20,000$ & ispl & $\$ 40,000$ \\
\hline & Liquid Waste (See Subtask 7.1) & & 3,000 & gal & & & & \\
\hline & Subtask Subtotal & & & & 3,392 & & & $\$ 243,153$ \\
\hline \multirow[t]{13}{*}{2.5} & $\begin{array}{l}\text { Inspect Lines (Visual Verification) } \\
\text { Duration: } 80 \text { Days }\end{array}$ & & & & & & & \\
\hline & $\begin{array}{l}\text { Project Management } \\
\text { Operations Manager }\end{array}$ & 1 & 16 & $\mathrm{hr}$ & 16 & $\$ 59$ & $\mathrm{hr}$ & $\$ 944$ \\
\hline & $\begin{array}{l}\text { Operations Manager } \\
\text { Engineer(s) (Project) }\end{array}$ & 11 & 16 & $\mathrm{hr}$ & 16 & $\$ 59$ & $/ \mathrm{hr}$ & $\$ 944$ \\
\hline & Engineer(s) (Project) & 1 & 64 & $\mathrm{hr}$ & 64 & $\$ 59$ & $\mathrm{hr}$ & $\$ 3,776$ \\
\hline & Other Exempt (ECO, RaaCon, Proc. Writer, Safey, $Q A)$ & 4 & 40 & $\mathrm{hr}$ & 160 & $\$ 59$ & hir & $\$ 9,440$ \\
\hline & Plannerischeduler & 11 & 40 & $\mathrm{hr}$ & 400 & $\$ 59$ & $\mathrm{hr}$ & $\$ 2,360$ \\
\hline & "HPT & 1 & 216 & "hr & 216 & $\$ 50$ & "Thr & $\$ 10,800$ \\
\hline & Operator & 2 & 108 & $\mathrm{hr}$ & 216 & $\$ 50$ & "ihr & $\$ 10,800$ \\
\hline & Craft Support (Pipe Fitter) & 1 & 176 & $\mathrm{hr}$ & 176 & $\$ 78$ & $\pi \mathrm{hr}$ & $\$ 13,728$ \\
\hline & Contract Support (Video Camera Operation) & 3 & 192 & $\mathrm{hr}$ & 576 & $\$ 70$ & $\mathrm{Thr}$ & $\$ 40,320$ \\
\hline & Misc. Supplies \& Equipment (10\% Labor) & & & & & & & $\$ 7,565$ \\
\hline & Materials (Video Equipment) & & & & & & & $\$ 27,900$ \\
\hline & Subtask Subtotal & & & & 1,480 & & & $\$ 128,577$ \\
\hline \multirow[t]{14}{*}{2.6} & Stabilize RLWS Valve Boxes & & & & & & & \\
\hline & Duration: 90 Days & & & & & & & \\
\hline & Project Management & 1 & 60 & $\mathrm{hr}$ & 60 & $\$ 59$ & $\mathrm{hr}$ & $\$ 3,540$ \\
\hline & Operations Manager & 1 & 30 & $\mathrm{hr}$ & 30 & $\$ 59$ & $\mathrm{hr}$ & $\$ 1,770$ \\
\hline & Engineer(s) (Project, Design) & 2 & 300 & $\mathrm{hr}$ & 600 & $\$ 59$ & $\mathrm{hr}$ & $\$ 35,400$ \\
\hline & Other Exempt (ECO, RadCon, Proc.Writer, Safety, QA) & 3 & 60 & $\mathrm{hr}$ & 180 & $\$ 59$ & $\mathrm{hr}$ & $\$ 10,620$ \\
\hline & Planner/scheduler & 1 & 120 & $\mathrm{hr}$ & 120 & $\$ 59$ & $7 \mathrm{hr}$ & $\$ 7,080$ \\
\hline & "HPT & 1 & 360 & $\mathrm{hr}$ & 360 & $\$ 50$ & thr & $\$ 18,000$ \\
\hline & Operator & 2 & 360 & $\mathrm{hr}$ & 720 & $\$ 50$ & $\mathrm{mr}$ & $\$ 36,000$ \\
\hline & Craft Support (Electrician) & 1 & 120 & $\mathrm{hr}$ & 120 & $\$ 78$ & $\mathrm{hr}$ & $\$ 9,360$ \\
\hline & Misc. Supplies \& Equipment (10\% Labor) & & & & & & & $\$ 6,336$ \\
\hline & Equipment (Scabbler Air compressor) & & 72 & $\mathrm{hr}$ & & $\$ 100$ & $\mathrm{Th}$ & $\$ 7,200$ \\
\hline & RMWWaste & & 0.26 & $\mathrm{~m}^{3}$ & & $\$ 2.410$ & $\mathrm{~m} 3$ & $\$ 627$ \\
\hline & Subtask Subtotal & & & & 2,190 & & & $\$ 135,933$ \\
\hline \multirow[t]{10}{*}{2.7} & Document Turnover Package Items & & & & & & & \\
\hline & $\begin{array}{l}\text { Duration: } 5 \text { Days } \\
\text { Project Management }\end{array}$ & 1 & 8 & hr & $8 \stackrel{3}{3}$ & $\$ 59$ & thr & $\$ 472$ \\
\hline & Operations Manager & 1 & 8 & $\mathrm{hr}$ & 8 & $\$ 59$ & $\mathrm{hr}$ & $\$ 472$ \\
\hline & Engineer(s) (Project) & 1 & 40 & $\mathrm{hr}$ & 40 & $\$ 59$ & $\mathrm{Thr}$ & $\$ 2,360$ \\
\hline & Other Exempt) (Safety) & 1 & 40 & $\mathrm{hr}$ & 40 & $\$ 59$ & $\mathrm{hr}$ & $\$ 2,360$ \\
\hline & Clerk & 1 & 20 & $\mathrm{hr}$ & 201 & $\$ 40$ & $\mathrm{hr}$ & $\$ 800$ \\
\hline & Subtask Subtotal & & & & 116 & & & $\$ 6,464$ \\
\hline & MPR or GFS ( $7 \%$, applied where applicable) & & & & & & & $\$ 10,844$ \\
\hline & $G \& A$ ( $15 \%$ on all - see note 1 at end of table) & & & & & & & $\$ 103,871$ \\
\hline & SUBTOTAL TASK 2.0 & & & & 9104 & & & $\$ 796,345$ \\
\hline
\end{tabular}


HNF-2230 Rev. 0

Phase I WBS Cost Estimate Work Sheets

\begin{tabular}{|c|c|c|c|c|c|c|c|c|}
\hline 3.0 & $\begin{array}{l}340 \text { Building Decon Area Deactivation } \\
\text { Duration: } 143 \text { Days }\end{array}$ & No. & Quantity & Unit & $\begin{array}{c}\text { Pers.: } \\
\text { Hrs }\end{array}$ & $\begin{array}{c}\text { Ratel } \\
\text { Amount }\end{array}$ & Unit & $\begin{array}{c}\text { Total } \\
\text { Dollars }\end{array}$ \\
\hline \multirow[t]{13}{*}{3.1} & $\begin{array}{l}\text { Decontaminate RLWS Related Sys. \& Components } \\
\text { Duration: } 21 \text { Days } \\
\text { Project Management }\end{array}$ & $1 \stackrel{\vdots}{\vdots}$ & 8 & $\mathrm{hr}$ & . & 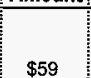 & hr & \\
\hline & Operations Manager & 1 & 4 & $\mathrm{hr}$ & 4 & $\$$ & $\frac{\mathrm{hr}}{\mathrm{hr}}$ & $\begin{array}{l}\$ 472 \\
\$ 236\end{array}$ \\
\hline & Engineer(s) (Project) & 1 & 24 & hi & 24 & $\$ 59$ & $\mathrm{hr}$ & $\$ 1,416$ \\
\hline & Other Exempt (ECO, RadCon, Proc.Writer, Safety, QA) & 3 & 40 & $\mathrm{hr}$ & 120 & $\$ 59$ & $\mathrm{hr}$ & $\$ 7,080$ \\
\hline & Planner/Scheduler & 1 & 32 & $h r$ & 32 & $\$ 59$ & $\mathrm{hr}$ & $\$ 1,888$ \\
\hline & HPT & 2 & 32 & $\mathrm{hr}$ & 64 & $\$ 50$ & $\mathrm{hr}$ & $\$ 3,200$ \\
\hline & Operator & 2 & 32 & $\mathrm{hr}$ & 64 & $\$ 50$ & $\mathrm{hr}$ & $\$ 3,200$ \\
\hline & Craft Support (Pipe Fitter) & 1 & 24 & $\mathrm{hr}$ & 24 & $\$ 78$ & $\mathrm{hr}$ & $\$ 1,872$ \\
\hline & Contract Support (Video Camera Operation) & 3 & 8 & $\mathrm{hr}$ & 24 & $\$ 70$ & $\mathrm{hr}$ & $\$ 1,680$ \\
\hline & Misc supplies \& Equipment ( $10 \%$ Labor) & & & & & & & $\$ 995$ \\
\hline & Decon Equipment (Purchased in Subtask 2.4) & & & & & & & \\
\hline & Liquid Waste (See Subtask 7.1) & & 200 & gal & & & & \\
\hline & Subtask Subtotal & & & & 364 & & & $\$ 22,039$ \\
\hline \multirow[t]{12}{*}{3.2} & $\begin{array}{l}\text { RLWS System Isolation } \\
\text { Duration: } 44 \text { Days }\end{array}$ & & & & & & & \\
\hline & Project Management & 1 & 8 & $\mathrm{hr}$ & 8 & $\$ 59$ & $/ \mathrm{hr}$ & $\$ 472$ \\
\hline & Operations Manager & 1 & 4 & $\mathrm{hr}$ & 4 & $\$ 59$ & /hr & $\$ 236$ \\
\hline & Engineer(s) (Project, Design) & 2 & 40 & hr & 80 & $\$ 50$ & $\mathrm{hhr}$ & $\$ 4,720$ \\
\hline & Other Exempt (ECO, RadCon, Proc.Writer, Safety, QA) & 3 & 24 & $\mathrm{hr}$ & 72 & $\$ 59$ & thr & $\$ 4,248$ \\
\hline & "Planner/Scheduler & 1 & 32 & $\mathrm{hr}$ & 32 & $\$ 59$ & $\mathrm{hhr}$ & $\$ 1,888$ \\
\hline & "НPF" & 2 & 32 & $\mathrm{hr}$ & 64 & $\$ 50$ & $\mathrm{hr}$ & $\$ 3,200$ \\
\hline & Operator & 2 & 32 & $\mathrm{hr}$ & 64 & $\$ 50$ & thr & $\$ 3,200$ \\
\hline & Craft Support (Pipe Fitter) & 1 & 24 & $\mathrm{hr}$ & 24 & $\$ 78$ & $\mathrm{hr}$ & $\$ 1,872$ \\
\hline & Misc. Supplies \& Equipment ( $10 \%$ Labor) & & & & & & & $\$ 827$ \\
\hline & RMWWaste & & 1.00 & $\mathrm{~m} 3$ & & $\$ 2,410$ & $/ \mathrm{m} 3$ & $\$ 2,410$ \\
\hline & Subtask Subtotal & & & & 348 & & & $\$ 23,073$ \\
\hline \multirow[t]{10}{*}{3.3} & $\begin{array}{l}\text { Housekeeping } \\
\text { Duration: } 25 \text { Days }\end{array}$ & & & & & & & \\
\hline & Project Management & 1 & 4 & $\mathrm{hr}$ & 4 & $\$ 59$ & $\mathrm{hr}$ & $\$ 236$ \\
\hline & Operations Manager & 1 & 2 & $\mathrm{hr}$ & 2 & $\$ 59$ & $\mathrm{hr}$ & $\$ 118$ \\
\hline & Engineer(s)(Project) & 1 & 8 & $\mathrm{hr}$ & 8 & $\$ 59$ & $/ \mathrm{hr}$ & $\$ 472$ \\
\hline & Other Exempt (ECO, RadCon, Proc.Writer, Safety, $Q A)$ & 1 & 8 & $\mathrm{hr}$ & 8 & $\$ 59$ & hr & $\$ 472$ \\
\hline & Plannerischeduler & 1 & 8 & $\mathrm{hr}$ & 8 & $\$ 59$ & Jhr & $\$ 472$ \\
\hline & $\mathrm{BPT}$ & 2 & 20 & $\mathrm{hr}$ & 40 & $\$ 50$ & he & $\$ 2,000$ \\
\hline & Operator & 2 & 40 & $\mathrm{hr}$ & 80 & $\$ 50$ & "Thr" & $\$ 4,000$ \\
\hline & Misc Supplies \& Equipment ( $10 \%$ Labor) & & & & & & & $\$ 600$ \\
\hline & Subtask Subtotal & & & & 150 & & & $\$ 8,370$ \\
\hline \multirow[t]{11}{*}{3.4} & Decontaminate and Stabilize Decon Area & & & & & & & \\
\hline & $\begin{array}{l}\text { Duration: } 25 \text { Days } \\
\text { Project Management }\end{array}$ & 1 & 8 & $\mathrm{hr}$ & 8 & $\$ 59$ & $/ \mathrm{hr}$ & $\$ 472$ \\
\hline & Manager & 1 & 4 & $\mathrm{hr}$ & 4 & $\$ 59$ & ihr & $\$ 236$ \\
\hline & Engineer(s) (Project) & 1 & 40 & $\mathrm{hr}$ & 40 & $\$ 59$ & his & $\$ 2,360$ \\
\hline & Other Exempt (ECO, RadCon, Proc.Writer, Safety, OA) & 3 & 8 & $\mathrm{hr}$ & 24 & $\$ 59$ & hir & $\$ 1,416$ \\
\hline & Planner/Scheduler & 1 & 16 & $\mathrm{hr}$ & 16 & $\$ 50$ & thr & $\$ 800$ \\
\hline & "HPT & 2 & 40 & $\mathrm{hr}$ & 80 & $\$ 50$ & thr & $\$ 4,000$ \\
\hline & Operator & 2 & 40 & $\mathrm{hr}$ & 80 & $\$ 50$ & thr & $\$ 4,000$ \\
\hline & E \& Equipment ( $10 \%$ Labor) & & & & & & & $\$ 800$ \\
\hline & Low Level Waste & & 0.52 & $\mathrm{~m}^{3}$ & & $\$ 1,900$ & $\mathrm{~m} 3$ & $\$ 988$ \\
\hline & Subtask Subtotal & & & & 252 & & & $\$ 15,072$ \\
\hline \multirow[t]{9}{*}{3.5} & Conduct Radiological Survey & & & & & & & \\
\hline & $\begin{array}{l}\text { Duration: } 15 \text { Days } \\
\text { Project Management }\end{array}$ & 1 & 4 & $\mathrm{hr}$ & 4 & $\$ 59$ & $/ \mathrm{hr}$ & $\$ 236$ \\
\hline & Operations Manager & 1 & 2 & $\mathrm{hr}$ & 2 & $\$ 59$ & hr & $\$ 118$ \\
\hline & Engineer(s) (Project) & 1 & 8 & hr & 8 & $\$ 59$ & $\mathrm{hhr}$ & $\$ 472$ \\
\hline & Other Exempt (ECO, RadCon, Proc.Writer, Safety, QA) & 3 & 16 & $\mathrm{hr}$ & 48 & $\$ 59$ & hin & $\$ 2,832$ \\
\hline & Plannerischeduler & 1 & 8 & $\mathrm{hr}$ & 8 & $\$ 59$ & $\mathrm{hr}$ & $\$ 472$ \\
\hline & - & 21 & 60 & $\mathrm{hr}$ & 120 & $\$ 50$ & $\mathrm{hhr}$ & $\$ 6,000$ \\
\hline & Misc. Supplies \& Equipment ( $10 \%$ Labor) & & & & & & & $\$ 600$ \\
\hline & Subtask Subtotal & & & & 190 & & & $\$ 10,730$ \\
\hline
\end{tabular}


HNF-2230 Rev. 0

Phase I WBS Cost Estimate Work Sheets

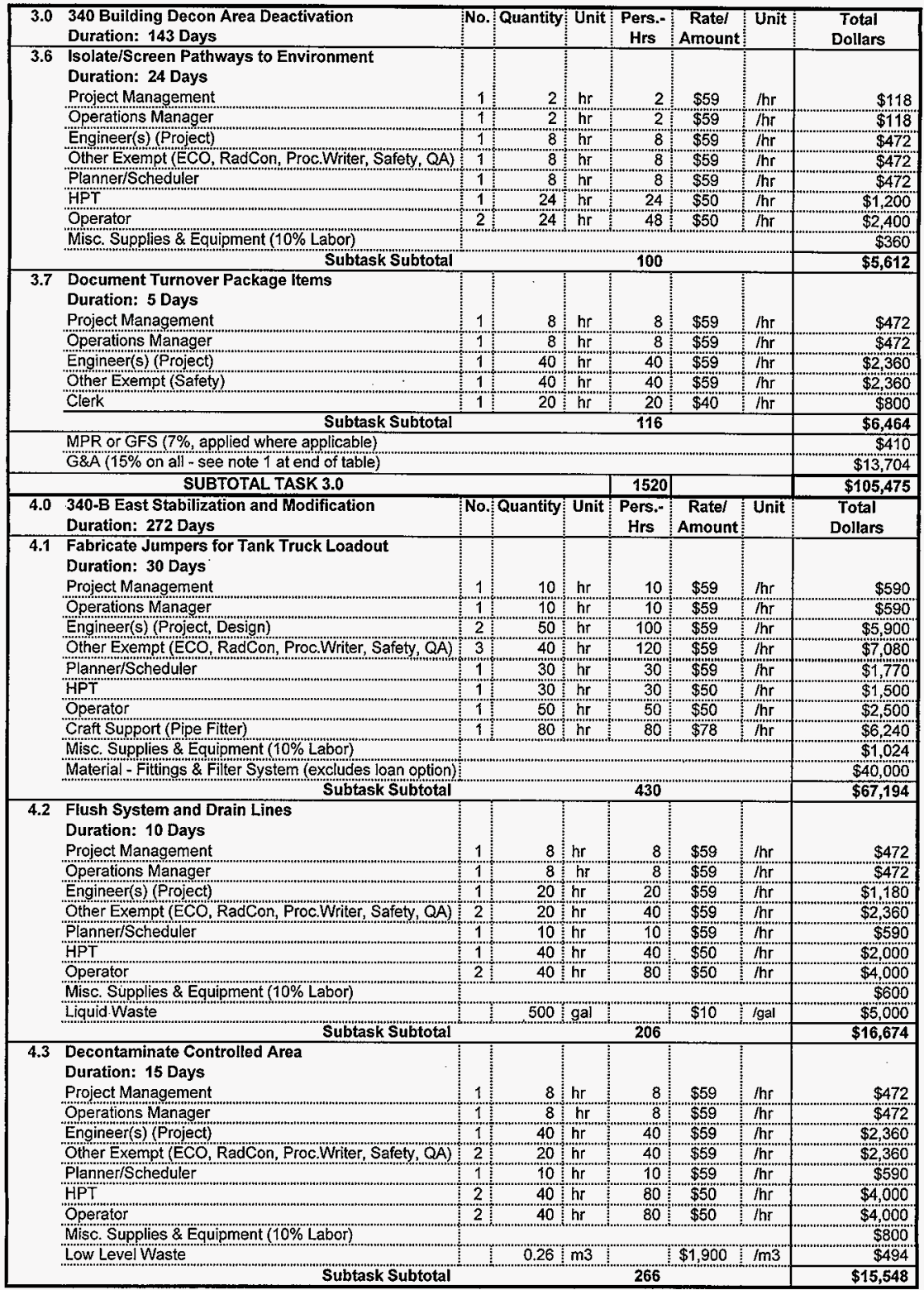


Phase I WBS Cost Estimate Work Sheets

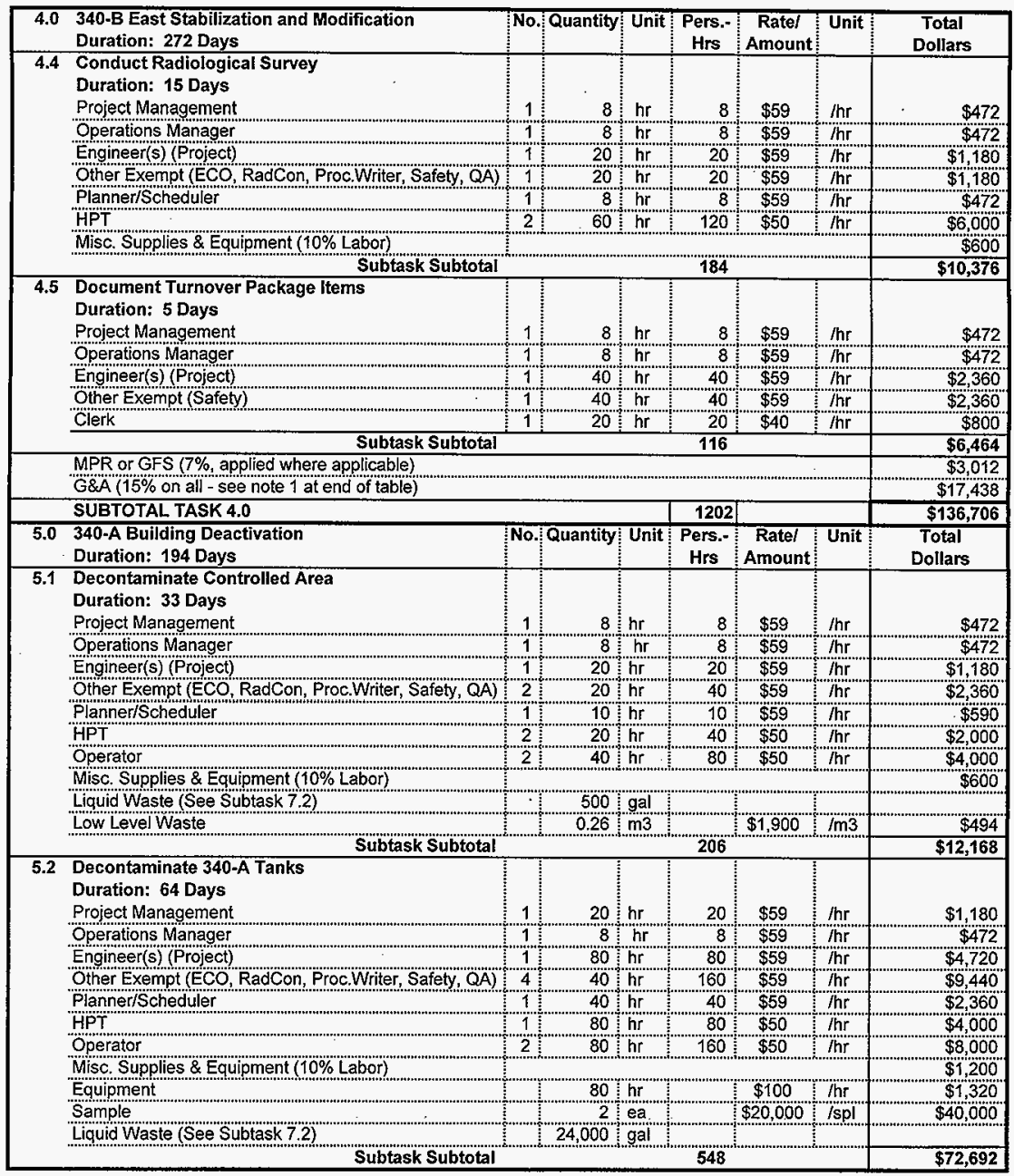


HNF-2230 Rev. 0

Phase I WBS Cost Estimate Work Sheets

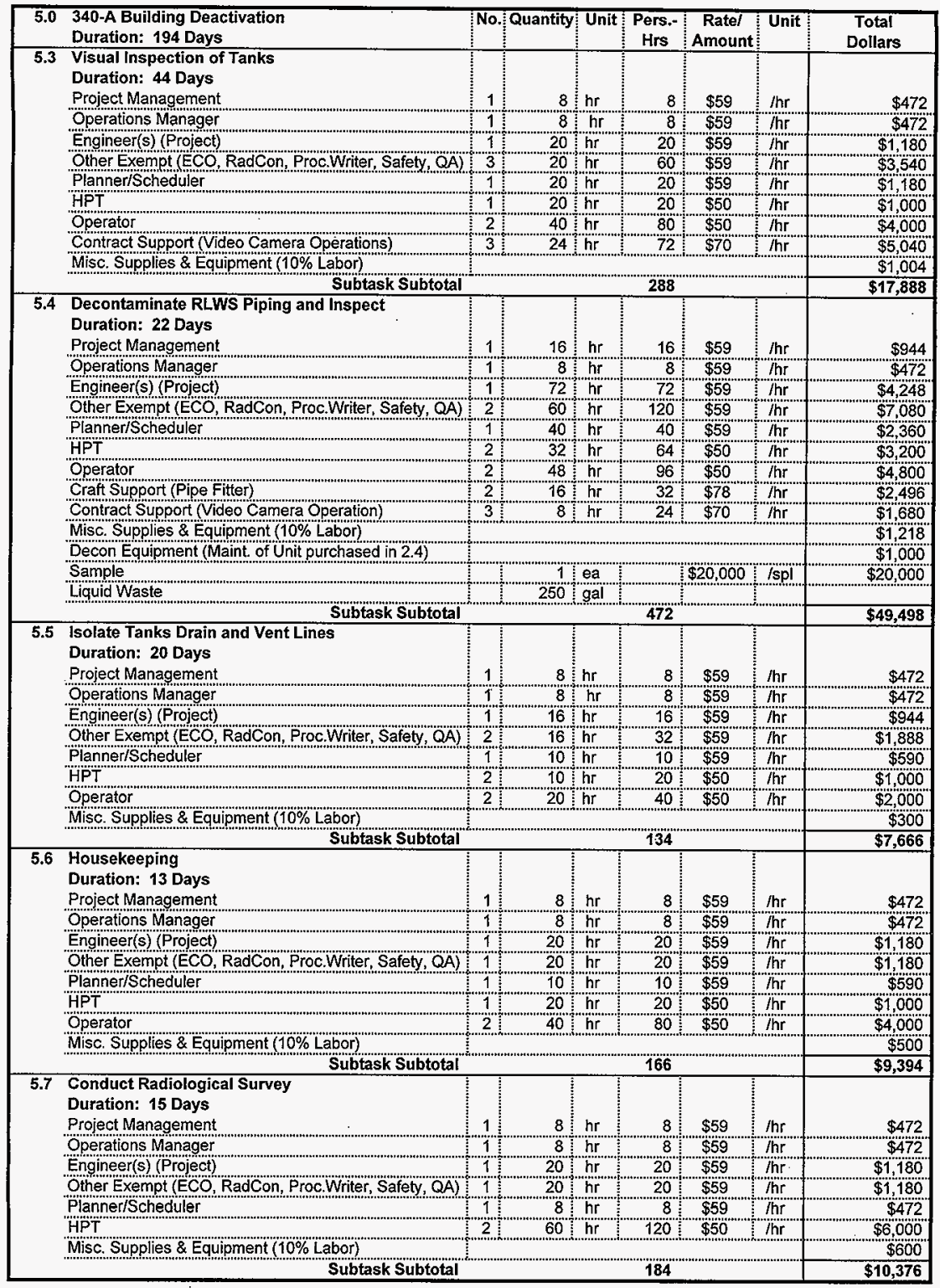


HNF-2230 Rev. 0

Phase I WBS Cost Estimate Work Sheets

\begin{tabular}{|c|c|c|c|c|c|c|c|c|}
\hline$\overline{5.0}$ & $\begin{array}{l}\text { 340-A Building Deactivation } \\
\text { Duration: } 194 \text { Days }\end{array}$ & No. & Quantity & Unit & $\begin{array}{l}\text { Pers.- } \\
\text { Hrs }\end{array}$ & $\begin{array}{c}\text { Rate/ } \\
\text { Amount }\end{array}$ & Unit & $\begin{array}{c}\text { Total } \\
\text { Dollars }\end{array}$ \\
\hline \multirow[t]{10}{*}{5.8} & Isolate/Screen Pathways to Environment & & & & & & & \\
\hline & $\begin{array}{l}\text { Duration: } 10 \text { Days } \\
\text { Project Management }\end{array}$ & 1 & 8 & hr & 8 & $\$ 59$ & $/ \mathrm{hr}$ & $\$ 472$ \\
\hline & Operations Manager & 1 & 8 & $\mathrm{hr}$ & 8 & $\$ 59$ & "hr & $\begin{array}{l}\$ 472 \\
\$ 472\end{array}$ \\
\hline & Engineer(s) (Project) & 1 & 16 & $\mathrm{hr}$ & 16 & $\$ 59$ & $\mathrm{hr}$ & $\$ 944$ \\
\hline & Other Exempt (ECO, RadCon, Proc.Writer, Safety, QA) & 1 & 16 & $\mathrm{hr}$ & 16 & $\$ 59$ & $\mathrm{hr}$ & $\$ 944$ \\
\hline & Plannerischeduler & 11 & 8 & $\mathrm{hr}$ & 8 & $\$ 59$ & hir & $\$ 472$ \\
\hline & HPT & 1 & 40 & $\mathrm{hr}$ & 40 & $\$ 50$ & $\mathrm{hr}$ & $\$ 2,000$ \\
\hline & Operator & 2 & 40 & hr & 80 & $\$ 50$ & $\mathrm{hr}$ & $\$ 4,000$ \\
\hline & Misc. Supplies \& Equipment (10\% Labor) & & & & & & & $\$ 600$ \\
\hline & Subtask Subtotal & & & & 176 & & & $\$ 9,904$ \\
\hline \multirow[t]{11}{*}{5.9} & $\begin{array}{l}\text { Deenergize } 340-A \text { Building Instrumentation and } \\
\text { Duration: } 35 \text { Days }\end{array}$ & & & & & & & \\
\hline & Project Management & 1 & 20 & $\mathrm{hr}$ & 20 & $\$ 59$ & hor & $\$ 1,180$ \\
\hline & Operations Manager & 1 & 8 & $\mathrm{hr}$ & 8 & $\$ 59$ & $\mathrm{hr}$ & $\$ 472$ \\
\hline & Engineer(s) (Project) & 1 & 80 & $\mathrm{hr}$ & 80 & $\$ 59$ & $\mathrm{hr}$ & $\$ 4,720$ \\
\hline & Other Exempt (ECO, RadCon, Proc. Writer, Safety, QA) & 2 & 40 & $\mathrm{hr}$ & 80 & $\$ 59$ & $\mathrm{hr}$ & $\$ 4,720$ \\
\hline & Plannerischeduler & 1 & 40 & $\mathrm{hr}$ & 40 & $\$ 59$ & thr & $\$ 2,360$ \\
\hline & HPT & 1 & 20 & $\mathrm{hr}$ & 20 & $\$ 50$ & thr & $\$ 1,000$ \\
\hline & Operator & 2 & 40 & $\mathrm{hr}$ & 80 & $\$ 50$ & $\mathrm{hr}$ & $\$ 4,000$ \\
\hline & "Craft Support (Electrician) & 11 & 40 & $\mathrm{hr}$ & 40 & $\$ 78$ & $\mathrm{hr}$ & $\$ 3,120$ \\
\hline & Misc Supplies \& Equipment (10\% Labor) & & & & & & & $\$ 812$ \\
\hline & Subtask Subtotal & & & & 368 & & & $\$ 22,384$ \\
\hline \multirow[t]{10}{*}{5.10} & Document Turnover Package Items & & & & & & & \\
\hline & $\begin{array}{l}\text { Duration: } 5 \text { Days } \\
\text { Project Management }\end{array}$ & 1 & 8 & $\mathrm{hr}$ & 8 & $\$ 59$ & $\mathrm{hr}$ & $\$ 472$ \\
\hline & Operations Manager & 1 & 8 & $h r$ & 8 & $\$ 59$ & $\mathrm{hr}$ & $\$ 472$ \\
\hline & Engineer & 11 & 40 & $\mathrm{hr}$ & 40 & $\$ 59$ & $\mathrm{hr}$ & $\$ 2,360$ \\
\hline & Other Exempt (Safety) & 1 & 40 & $\mathrm{hr}$ & 40 & $\$ 59$ & hir & $\$ 2,360$ \\
\hline & Clerk & 1 & 20 & $\mathrm{hr}$ & 20 & $\$ 40$ & ihr & $\$ 800$ \\
\hline & Subtask Subtotal & & & & 116 & & & $\$ 6,464$ \\
\hline & MPR or GFS (7\%, applied where applicable) & & & & & & & $\$ 1,111$ \\
\hline & G\&A ( $15 \%$ on all - see note 1 at end of table) & & & & & & & $\$ 32,765$ \\
\hline & SUBTOTAL TASK 5.0 & & & & 2658 & & & $\$ 252,310$ \\
\hline 6.0 & $\begin{array}{l}340 \text { Vault Decontamination } \\
\text { Duration: } 230 \text { Days }\end{array}$ & No. & Quantity & Unit & $\begin{array}{l}\text { Pers.- } \\
\text { Hrs }\end{array}$ & $\begin{array}{c}\text { Ratel } \\
\text { Amount }\end{array}$ & Unit & $\begin{array}{l}\text { Total } \\
\text { Dollars }\end{array}$ \\
\hline \multirow[t]{14}{*}{6.1} & Decontaminate Vault \& Tanks & & & & & & & \\
\hline & Duration: 60 Days & & & & & & & \\
\hline & Project Management & 11 & 40 & $\mathrm{hr}$ & 40 & $\$ 59$ & $\mathrm{hr}$ & $\$ 2,360$ \\
\hline & Operations Manager & 1 & 8 & $\mathrm{hr}$ & 8 & $\$ 59$ & $\mathrm{hr}$ & $\$ 472$ \\
\hline & Engineer(s) (Project) & 11 & 80 & $\mathrm{hr}$ & 80 & $\$ 59$ & hrr & $\$ 4,720$ \\
\hline & Other Exempt (ECO, RadCon, Proc.Writer, Safety, $Q A)$ & 4 & 80 & $\mathrm{hr}$ & 320 & $\$ 59$ & $\mathrm{hr}$ & $\$ 18,880$ \\
\hline & Planner/Scheduler & 11 & 40 & $\mathrm{hr}$ & 40 & $\$ 59$ & thr & $\$ 2,360$ \\
\hline & "HPT" & 2 & 160 & $\mathrm{hr}$ & 320 & $\$ 50$ & hr & $\$ 16,000$ \\
\hline & Operator & 3 & 160 & $\mathrm{hr}$ & 480 & $\$ 50$ & hrt & $\$ 24,000$ \\
\hline & Misc. Supplies \& Equipment (10\% Labor) & & & & & & & $\$ 4,000$ \\
\hline & Material (Filtration Unit) & & & & & & & $\$ 3,000$ \\
\hline & RMW Waste & & 100 & $\mathrm{m3}$ & & $\$ 2,410$ & $m 3$ & $\$ 2,410$ \\
\hline & Liquid Waste (See Subtask 7.3) & & 700 & gal. & & & & \\
\hline & Subtask Subtotal & & & & 1,288 & & & $\$ 78,202$ \\
\hline
\end{tabular}


HNF-2230 Rev. 0

Phase I WBS Cost Estimate Work Sheets

\begin{tabular}{|c|c|c|c|c|c|c|c|c|}
\hline 6.0 & $\begin{array}{l}340 \text { Vault Decontamination } \\
\text { Duration: } 230 \text { Days }\end{array}$ & No.? & Quantity & Unit & $\begin{array}{l}\text { Pers.: } \\
\text { Hrs }\end{array}$ & $\begin{array}{c}\text { Ratel } \\
\text { Amount }\end{array}$ & Unit & $\begin{array}{l}\text { Total } \\
\text { Dollars }\end{array}$ \\
\hline \multirow[t]{14}{*}{6.2} & $\begin{array}{l}\text { Decon RLWS 340-BE Piping and Inspect } \\
\text { Duration: } 60 \text { Days }\end{array}$ & & & & & & & \\
\hline & $\begin{array}{l}\text { Project Management } \\
\text { Operations Manager }\end{array}$ & 1 & 16 & hr & 16 & $\$ 59$ & hr & $\$ 944$ \\
\hline & Engineer(s) (Project) & 1 & 72 & $\mathrm{hr}$ & 72 & $\begin{array}{l}\$ 59 \\
\$ 59\end{array}$ & $\frac{\mathrm{hr}}{\mathrm{hr}}$ & $\begin{array}{r}\$ 472 \\
\$ 4,248\end{array}$ \\
\hline & Other Exempt (ECO, RadCon, Proc.Writer, Safety, $Q A)$ & 2 & 72 & $\mathrm{hr}$ & 144 & $\$ 59$ & $/ \mathrm{hr}$ & $\$ 8,496$ \\
\hline & Planner/Scheduler & 1 & 40 & $\mathrm{hr}$ & 40 & $\$ 59$ & thr & $\$ 2,360$ \\
\hline & HPT & 2 & 32 & $h r$ & 64 & $\$ 50$ & $\mathrm{hr}$ & $\$ 3,200$ \\
\hline & Operator & 2 & 48 & $\mathrm{hr}$ & 96 & $\$ 50$ & $\mathrm{hr}$ & $\$ 4,800$ \\
\hline & Craft Support (Pipe Fitter) & 4 & 16 & $h r$ & 64 & $\$ 78$ & hhr & $\$ 4,992$ \\
\hline & Contract Support Nideo Camera Operation) & 3 & 8 & $\mathrm{hr}$ & 24 & $\$ 70$ & thr & $\$ 1,680$ \\
\hline & Misc. Supplies \& Equpment (10\% Labor) & & & & & & & $\$ 1,467$ \\
\hline & Decon Equipment (Maint of Unit purchased in 2.4) & & & & & & & $\$ 1,000$ \\
\hline & Sample & & 1 & $e a$ & & $\$ 20,000$ & $\mid \mathrm{spl}$ & $\$ 20,000$ \\
\hline & Liquid Waste (See Subtask 7.3) & & 500 & gal & & & & \\
\hline & Subtask Subtotal & & & & 528 & & & $\$ 53,659$ \\
\hline \multirow[t]{12}{*}{6.3} & $\begin{array}{l}\text { Erect Greenhouse/ Install Exhauster } \\
\text { Duration: } 50 \text { Days }\end{array}$ & & 8 & & & & & \\
\hline & $\begin{array}{l}\text { Project Management } \\
\text { Operations Manager }\end{array}$ & $1:$ & 8 & $\mathrm{hr}$ & 8 & $\begin{array}{l}\$ 59 \\
\$ 59\end{array}$ & (hr & $\begin{array}{l}\$ 472 \\
\$ 472\end{array}$ \\
\hline & Engineer(s) (Project) & 1 & 24 & & 24 & $\$ 59$ & his & $\begin{aligned} \$ 472 \\
\$ 1,416\end{aligned}$ \\
\hline & Other Exempt (ECO RadCon, Proc Writer, Safety, QA) & 3 & 16 & & 48 & $\$ 59$ & thr & $\$ 2,832$ \\
\hline & PlanneriScheduler & 11 & 16 & & 16 & $\$ 59$ & thr & $\$ 944$ \\
\hline & $H P T$ & 1 & 16 & & 16 & $\$ 50$ & ihr & $\$ 800$ \\
\hline & Operator & 2 & 24 & & 48 & $\$ 50$ & /hr & $\$ 2,400$ \\
\hline & Craft Support (Inst., Electrician, Carpenter) & 3 & 24 & hr & 72 & $\$ 78$ & ihr & $\$ 5,616$ \\
\hline & Vent and Balance Personnel & 21 & 16 & $\mathrm{hr}$ & 32 & $\$ 50$ & hr & $\$ 1,600$ \\
\hline & Misc. Supplies \& Equipment (10\% Labor) & & & & & & & $\$ 882$ \\
\hline & Materials - Greenhouse/ Portable Exhauster & & & & & & & $\$ 16,000$ \\
\hline & Subtask Subtotal & & & & 272 & & & $\$ 33,434$ \\
\hline \multirow[t]{12}{*}{6.4} & Remove HEPA Filters and Dispose & & & & & & & \\
\hline & $\begin{array}{l}\text { Duration: } 10 \mathrm{D} \\
\text { Project Manage }\end{array}$ & 1 & 8 & hr & 8 & 859 & & \\
\hline & Operations Manager & 1 & 8 & $\mathrm{hr}$ & 8 & $\$ 59$ & /hr & $\begin{array}{l}\$ 472 \\
\$ 472\end{array}$ \\
\hline & (s) (Proj & 1 & 16 & $\mathrm{hr}$ & 16 & $\$ 59$ & hin & $\$ 944$ \\
\hline & Other Exempt (ECO, RadCon, Proc.Writer, Safety, QA) & 3 & 20 & $\mathrm{hr}$ & 60 & $\$ 59$ & $\mathrm{hr}$ & $\$ 3,540$ \\
\hline & Plannerlscheduler & 1 & 16 & $\mathrm{hr}$ & 16 & $\$ 59$ & $\mathrm{hr}$ & $\$ 944$ \\
\hline & HPT & 2 & 20 & $\mathrm{hr}$ & 40 & $\$ 50$ & $7 \mathrm{hr}$ & $\$ 2,000$ \\
\hline & Operator & 21 & 20 & $\mathrm{hr}$ & 40 & $\$ 50$ & $\mathrm{hr}$ & $\$ 2,000$ \\
\hline & Misc. Supplies \& Equipment ( $10 \%$ Labor) & & & & & & & $\$ 400$ \\
\hline & Burial boxes & & 3 & box & & $\$ 3,200$ & ea & $\$ 9,600$ \\
\hline & Low Level Waste & & 11 & $m 3$ & & $\$ 1,900$ & $1 \mathrm{~m} 3$ & $\$ 20,900$ \\
\hline & Subtask Subtotal & & & & 188 & & & $\$ 41,272$ \\
\hline \multirow[t]{12}{*}{6.5} & Isolate K-1 Stack and Ducting & & & & & & & \\
\hline & $\begin{array}{l}\text { Duration: } 33 \text { Days } \\
\text { Project Management }\end{array}$ & $1 i$ & 4 & $\mathrm{hr}$ & 4 & $\$ 59$ & $/ \mathrm{hr}$ & $\$ 236$ \\
\hline & Operations Manager & $1 \stackrel{1}{3}$ & 8 & $\mathrm{hr}$ & 8 & $\$ 59$ & hir & $\$ 472$ \\
\hline & Engineer(s) (Project) & 1 & 8 & $\mathrm{hr}$ & 8 & $\$ 59$ & $\mathrm{hr}$ & $\$ 472$ \\
\hline & Other Exempt (ECO, RadCo, ProcWriter, Safety, $Q A)$ & 2 & 8 & $\mathrm{hr}$ & 16 & $\$ 59$ & $/ \mathrm{hr}$ & $\$ 944$ \\
\hline & Planner/Scheduler & 1 & 8 & $\mathrm{hr}$ & 8 & $\$ 59$ & $\mathrm{hr}$ & $\$ 472$ \\
\hline & HPT & 2 & 16 & $\mathrm{hr}$ & 32 & $\$ 50$ & $\mathrm{hr}$ & $\$ 1,600$ \\
\hline & Operator & 3 & 16 & $\mathrm{hr}$ & 48 & $\$ 50$ & $\mathrm{hr}$ & $\$ 2,400$ \\
\hline & Craft Support (Sheet Metal) & 1 & 24 & $\mathrm{hr}$ & 24 & $\$ 78$ & hir & $\$ 1,872$ \\
\hline & Misc supplies \& Equipment (10\% Labor) & & & & & & & $\$ 587$ \\
\hline & Material (Blanks, flanges) & & & & & & & $\$ 400$ \\
\hline & Subtask Subtotal & & & & 148 & & & $\$ 9,455$ \\
\hline
\end{tabular}


HNF-2230 Rev. 0

Phase I WBS Cost Estimate Work Sheets

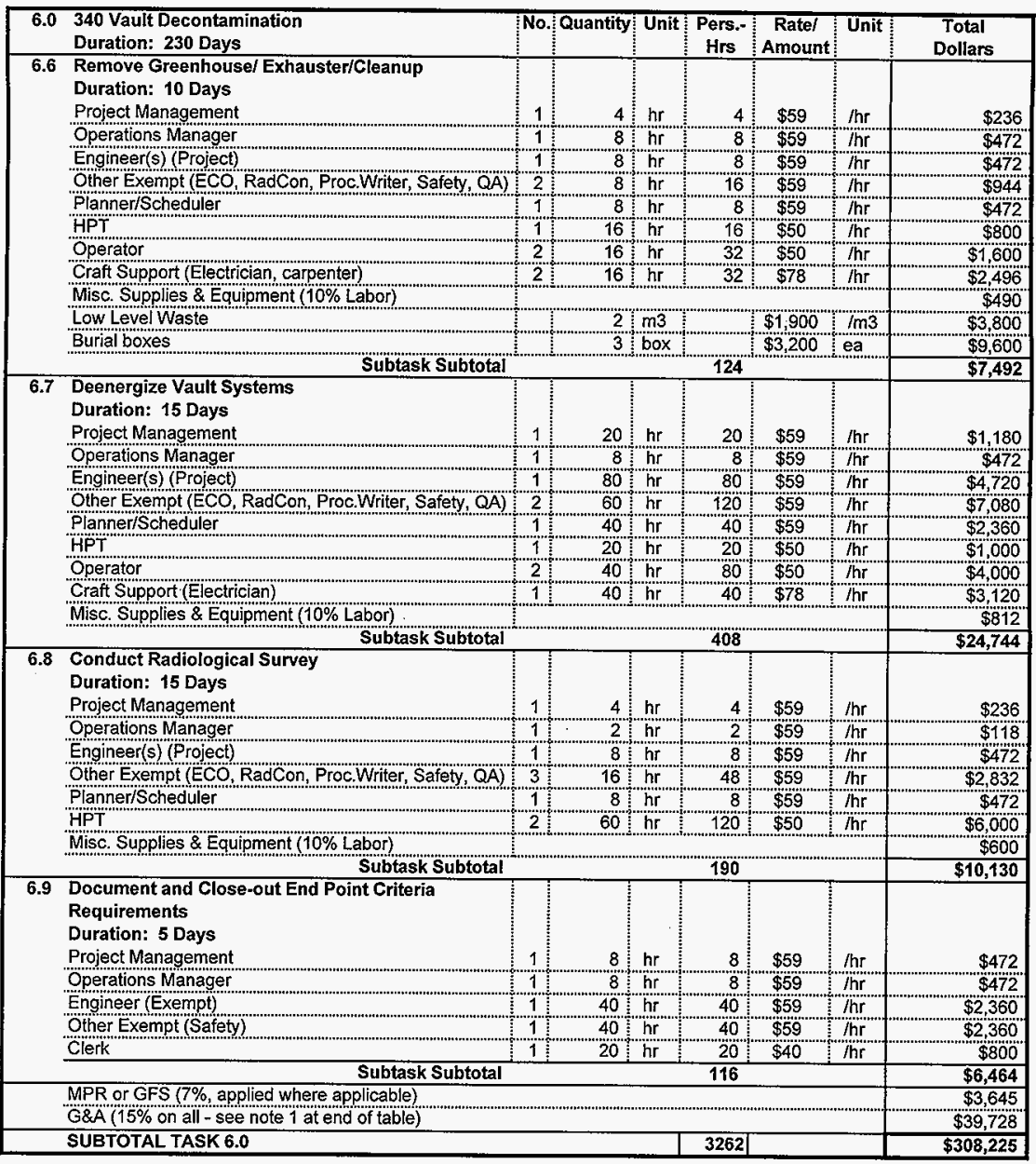


HNF-2230 Rev. 0

Phase I WBS Cost Estimate Work Sheets

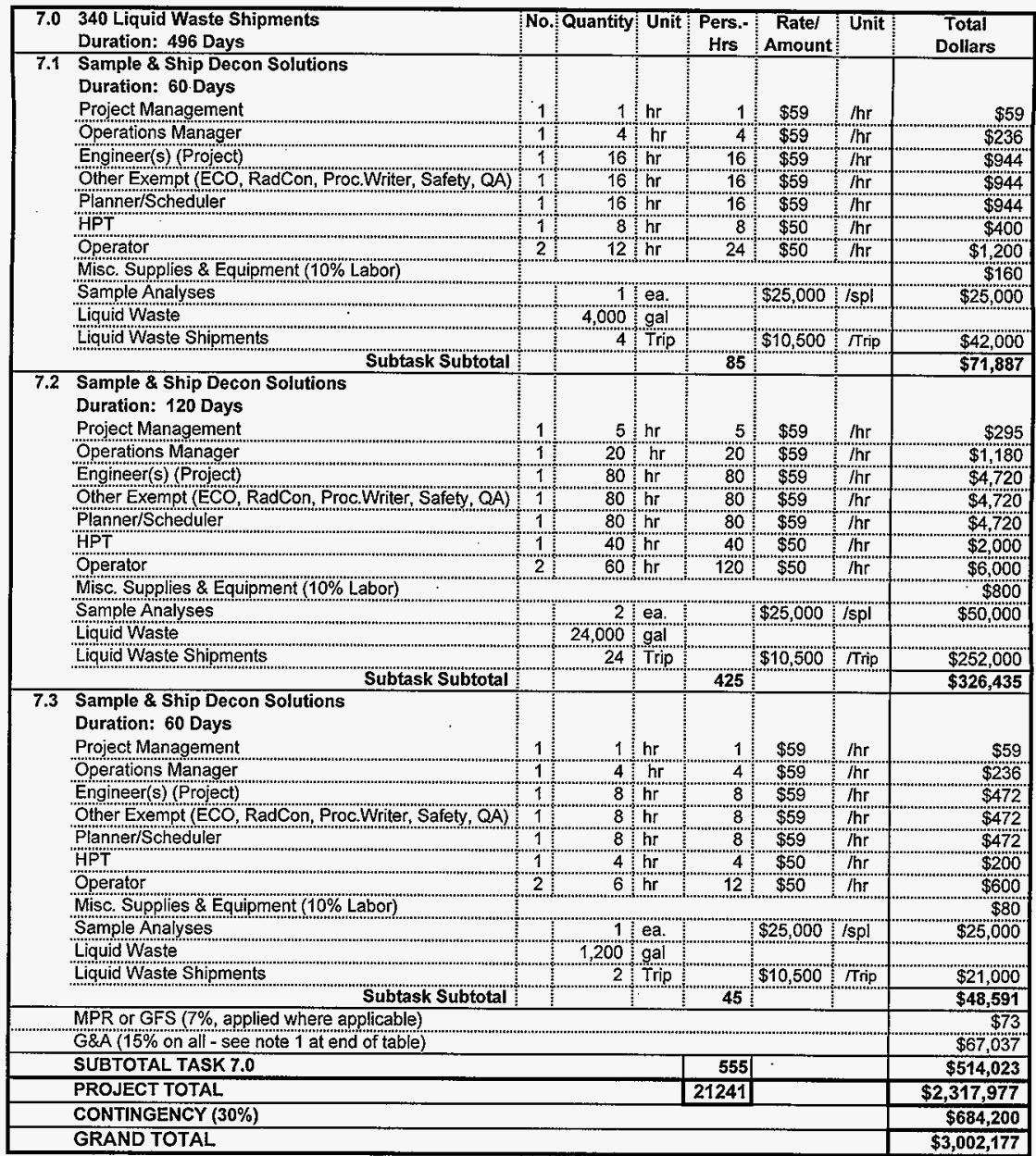

Note 1: The FY99 G\&A rate is $15 \%$. While it will rise to $22 \%$ for out-years, the MPR simultaneously goes away; therefore, no attempt is made here to segregate tasks by year for these overhead adders (this may slightly lower total estimate).

Note 2: Miscellaneous supplies (PPE, wipes, etc.) are estimated at a percentage of operator, craft, and HPT costs.

Durations are work days, not straight calendar days, and account for outside reviews, analytical turn around time, etc., in addition to hours listed here. 
HNF-2230 Rev. 0

\begin{tabular}{|c|c|c|}
\hline \multicolumn{3}{|c|}{ Phase II Cost Summary } \\
\hline Task No. & Task Description & Total Dollars \\
\hline 1.0 & Administrative/Engineering Documentation* & 180,000 \\
\hline 2.0 & Vault and Valve Pit Deactivation (Tanks to TSD) & 660,000 \\
\hline 3.0 & 340 Building Control Room Deactivation & 47,000 \\
\hline 4.0 & 340 Building Mech. Equipment Rm Deactivation & 34,000 \\
\hline 5.0 & 340 Building Decon Area Deactivation & 43,000 \\
\hline 6.0 & $\begin{array}{l}340 \text { Building Truck Lock/Mezzanine/Office } \\
\text { Deactivation }\end{array}$ & 48,000 \\
\hline 7.0 & 340-B Building (East $\&$ West) Deactivation & 70,000 \\
\hline 8.0 & 3707-F Building Deactivation & 23,000 \\
\hline 9.0 & 307 Basin Deactivation & 47,000 \\
\hline 10.0 & $\begin{array}{l}\text { Balance of } 340 \text { Complex (MOs/yard/etc) } \\
\text { Deactivation }\end{array}$ & 70,000 \\
\hline 11.0 & 340-A Bldg. Final Deactivation & 3,000 \\
\hline \multirow[t]{3}{*}{12.0} & Facility Transfer to ERC & 10,000 \\
\hline & Subtotal & $1,240,000$ \\
\hline & G\&A (22\%) & 270,000 \\
\hline \multirow[t]{3}{*}{. } & Subtotal & $1,500,000$ \\
\hline & Contingency $(35 \%)$ & 530,000 \\
\hline & Total (non-escalated 1998) & $\$ 2.000,000$ \\
\hline \multicolumn{3}{|c|}{ Potential Phase II Tasks } \\
\hline TBD & Remove AGS Tanks, Dismantle 340-A, Decon Pad & $\$ 690,000$ \\
\hline TBD & Retrieve and Dispose of RLWS Piping System & $\$ 3,200,000$ \\
\hline
\end{tabular}

* S\&M Plan, final EPC document, Revise this PMP, NOC for tank removal and vault decon, final FHA, roof \& structure analysis, asbestos assessment, final safety basis, etc. [Note, assumed interim monitoring costs will becovered under continuing RPS operations] 
HNF-2230 Rev. 0

\title{
APPENDIX C - WBS TASK DESCRIPTIONS
}

\section{DEACTIVATION TASKS}

This Appendix $C$ identifies and describes the task packages that will be implemented in order to complete the planned work (Phase I only).

\section{TASK PACKAGE 1.0: DOCUMENTATION}

Task Package 1.0 involves the preparation and/or revision of documents, listed below, needed to meet regulatiory requirements that will authorize and support Phase I deactivation work.

\author{
1.1 USQ Screening \\ 1.2 Administrative Manuals \\ 1.3 Prepare and maintain centralized file for turnover package items \\ 1.4. Transporter Approvals \\ 1.5 ISB Revision \\ 1.6 Revise FEMP \\ 1.7 Revise CSER \\ 1.8 Prepare Interim Monitoring Plan \\ 1.9 Prepare Notice of Construction for Vault clean out work \\ 1.10 Deactivation Fire Hazard Analysis \\ 1.11 ISB Revision (second) \\ 1.12 Regulatory Status Evaluation, Task 2.0 \\ 1.13 Regulatory Status Evaluation, Task 3.0 \\ 1.14 Regulatory Status Evaluation, Task 5.0 \\ 1.15 Regulatory Status Evaluation, Task 6.0
}

TASK PACKAGE 2.0: RLWS SYSTEM ISOLATION (Decouple RPS from RLWS)

\section{Background for Task Package 2.0}

The RLWS is composed of encased stainless steel piping connecting the 340 Complex Vault Tanks to the five waste generator facilities in the 300 Area. The RLWS system is used to direct liquid mixed waste to the 340 Complex vault tanks. Facilities connected to the RLWS system are the $324,325,326,327$, and 329 . buildings. Associated with the RLWS system are 15 concrete valve boxes that serve as 'engineered' manholes for the encased pipe-in-pipe system. The valve boxes are equipped with leak detection instrumentation and the piping is configured with system clean out ports. There is approximately $800 \mathrm{~m}(2,600 \mathrm{ft})$ of buried RLWS piping between the generator facilities and the 340 Vault. The inside volume of this RLWS piping is approximately $5.7 \mathrm{~kL}$ $(1,500-$ gal). 
The RPS system provides process wastewater with an alternate route for disposal should significant radioactivity be detected. The current configuration diverts the generator facility process wastewater to the 340 RLWS Vault tanks when significant radiation is detected. This path will be eliminated once the RLWS system is shut down. There are currently two locations in the RPS system that allow waste to be routed away from the process sewer. The first is at the generator building, where if radioactivity is detected in the RPS flow, it is diverted to the RLWS Vault tanks. The second location for wastewater diversion is the 307 Basins. These basins are subject to batch sampling. If radioactivity is detected, the contents of the basins can be pumped directly into the RLWS Vault tanks. With the elimination of the RLWS system, a potential diversion of the RPS will be routed to a dedicated 307 Basin for temporary holdup. After required sampling, the basin liquid will be rerouted around the 340 Vault tanks directly to the 340-B East liquid waste load-out station.

\section{Scope of Task Package 2.0}

- Reconfigure RPS alarm/signal to 3707-F Building which involves rewiring generator facility divert signals to existing RLWS wiring and modifying 307 Basin inlet manifold operating software to shunt entire RPS flow to dedicated basin in event any upstream monitors signal a divert;

- Install communication hardware and fiber optic link to 3707-F, to include network router. This communication upgrade will allow a reliable data link between $3707-\mathrm{F}$ and the TEDF control room.

- Cap and isolate RLWS lines at the flange inside each of the generator buildings;

- Install Vault tank bypass from one 307 Basin to 340-B East load-out station;

- Decontaminate approximately $800 \mathrm{~m}(2,600 \mathrm{ft})$ of RLWS pipe with EPA-approved physical extraction technology; rinse RLWS piping and drain to the vault tanks, and collect sample of the rinse solution;

- Inspect lines (visual verification with remote video camera system);

- Stabilize the 15 valve boxes between the generator facilities and Vault tanks; prepare and file relevant documentation and place in transition turnover package;

- Prepare relevant project documentation and place in 340 Complex transition turnover package file.

\section{Approach for Task Package 2.0}

Preliminary to deactivating the RLWS system, modifications to the RPS divert process will be implemented to prevent waste liquid from accumulating in the Vault tanks. This will be accomplished by reconfiguring the generator facility divert actuators so that when radioactivity is detected in the RPS flow it will be diverted to a dedicated 307 basin. Rewiring monitor alarms directly to the 3707-F Building controls will harden the reliability over existing phone line connections. Capping each of the RLWS lines at the generator facility will afford positive isolation of the RLWS system. In order to remove the accumulated liquid from the basin, a temporary hose connection will be installed on the outlet of the basin discharge pump for loading into truck tank trailers.

Flushing activities will be initiated from inside the $324,325,326,327$ and 329 facilities, 
or adjacent valve boxes. Existing valving and piping will be used to assure flow and wetting of all surfaces. The RLWS piping will be cleaned in sections. The internal surfaces of the piping will be spray washed using a high pressure nozzle spray system. The nozzle system will be fed down through the section of pipe to be cleaned, and then withdrawn. The section of piping will then be rinsed and drained to the vault tanks. A representative sample from each flush may be collected and combined for analysis to verify effectiveness of flushing activities. Flush volumes will vary depending on the amount of piping, perceived need, and sampling results. The internal surface of the pipe section will be inspected with a video camera to obtain/document a clean surface determination.

Stabilization of valve boxes involves isolating the electrical supply to the leak detectors and local alarm panels, verifying system configuration, and posting requirements.

\section{Schedule for Task Package 2.0}

RLWS system isolation is scheduled for completion in FY99. The estimated duration of work is identified on the detailed schedule attached as Appendix D. Cost estimates, including materials and proposed team members, are are attached as Appendix B. It may be possible to expedite some of the planning and arrangements with the generators for this task during FY98, especially if currently proposed header flushes are conducted (Section 3.0).

\section{TASK PACKAGE 3.0: $\quad 340$ BUILDING DECON AREA STABILIZATION}

\section{Background for Task Package 3.0}

The Decon Area is located in the east section of the 340 Building and consists of an open radiologically controlled area containing a sample hood, sink, emergency shower and eyewash station, work benches and sump. The K3 Stack ventilation pre-filters are also located in this area. The Decon Area design allows decontamination and rinse solutions to drain to the sump, which discharges to the Vault tanks. The eyewash station and decon sink also drain to the sump. With the termination of the RLWS system, there is no routine operational need for the Decon Area facilities. The Decon Area will be placed in standby and only activated, for example, in the event of a diversion to the 307 Basins for sample preparation, or if routine batch release sample counting shows an activity level increase in the RPS system during clean out of upstream generator facilities.

\section{Scope of Task Package 3.0}

- Decontamination and inspection of RLWS piping from sump to Vault tanks;

- Removal of sump pump and drain lines to the sump, to include the Process Water back-flow preventer drain; remove and cap sample and drain lines, and valving inside the decon hood; deactivate the decon sink, emergency shower and eyewash station; 
when RLWS decontamination is complete, the sump liner will be removed and disposed of as RMW;

- Clean out and housekeeping of the 340 Decon Area which includes removal of stored waste containers, elimination of storage areas, and removal of unattached materials and equiment; although housekeeping is an ongoing activity integral to most field work, there are many commonly used materials (tools, step ladders, buckets, chain hoists, small pumps, hoses) that are routinely staged in rad zones as a waste minimization practice; the subtask housekeeping, here and elsewhere, covers the final clean out of these materials;

- Decontamination and stabilization of radiation and contamination areas which will be limited to the 340 Decon Area, east section of the 340 Building;

- Conduct radiological survey to document post-decontamination conditions and verify loose surface contamination has been stabilized;

- Isolate pathways to and from the environment to prevent contamination migration and vermin intrusion; and

- Prepare relevant project documentation and place in 340 Complex transition turnover package file.

\section{Approach for Task Package 3.0}

Flush Sample Lines and drain to Vault Tanks. Remove section of sample line inside hood (source of existing dose rate). Cap open ends of sample line and dispose of the removed section as radioactive mixed waste (RMW). Decontaminate internal surfaces of hood. This task will stabilize source of removable contamination and reduce radiological hazards. The hood may be required to be utilized for sample preparation in the event of a diversion to the 307 Basins. Remove sink and drain lines and dispose of as RMW. Decontaminate general vicinity around sink location. Fix contamination to prevent migration. Remove emergency shower and eyewash station, drain lines and dispose of as low-level waste (LLW). Remove and blank section of Process Water back-flow preventer that drains to sump.

Flush sump and drain to Vault Tanks. Remove sump pump for disposal. The internal surfaces of the piping will be decontaminated using a high pressure nozzle spray system. The nozzle system will be fed through the section of pipe from the sump to Valve Box No. 9. The section of piping will then be rinsed and drained to the vault tanks. The internal surface of the pipe section will be inspected with a video camera to obtain a clean surface determination. The line will then be capped with a blank flange. The stainless steel sump liner will then be removed and disposed of as RMW.

After decontamination and system isolation activities are completed, housekeeping and clean out activities will be initiated in preparation of general area decontamination. Decontamination will be accomplished using conventional techniques and methods to include fixatives. Conduct final radiological survey of the 340 Decon Area. Post radiological conditions as required by HSRCM-1 (Hanford 1997). 


\section{Schedule for Task Package $\mathbf{3 . 0}$}

The 340 Decon Area stabilization activities are scheduled for completion in FY99. The estimated duration of work is identified on the detailed schedule attached as Appendix D. Cost estimates, including materials and proposed team members, are attached as Appendix B.

\section{TASK PACKAGE 4.0: $\quad 340-B$ EAST BUILDING STABILIZATION AND MODIFICATION}

\section{Background for Task Package 4.0}

The 340-B Building will be retained for 307/RPS operation. The 340-B West portion of the building will continue to be used for storage. The 340-B East portion will no longer be used for rail car transfers based on rail service termination at end of FY98. However, in order to continue the WMH mission of managing the RPS system so that potential diverts to the designated 307 Basin can be transferred, 340-B East will be modified to service truck tank trailers ${ }^{5}$. This modification would also accomodate transfers of deactivation, related RLWS clean out and decon solutions Current flex hose connections for rail car transfers are incompatible with existing on-site truck tank trailer fittings. Also, the LR56 tanker cannot accommodate solids as readily as the rail tanker.

\section{Scope of Task Package 4.0}

- Design, fabricate, and install jumper adaptors for tank truck load-out;

- Design, fabricate or purchase, and install filter system for tank truck load-outs;

- Flush load-out bay drain system and RLWS load-out piping in preparation for system decontamination;

- Decontaminate the 340-B East radiologically controlled area to reduce and/or eliminate radiological hazards;

- Conduct radiological survey to document existing conditions and post it in accordance with HSCRM-1 criteria; and

- Prepare and file relevant project documentation and place in 340 Complex transition turnover package file.

\section{Approach for Task Package 4.0}

Flush liquid waste transfer piping and drains to Vault tanks for ALARA considerations. Decontaminate the controlled radiological area in 340-B East. Decontamination of the work area will facilitate modification activities. Plan, prepare work packages, purchase

${ }^{5}$ Other tasks, e.g., Tasks 2.1, 2.2, and 3.2 in Phase I, and Task 7.6 in Phase Il in addition to this, address related aspects of this overall objective to decouple the RPS system and allow it to continue to operate. 


\section{HNF-2230 Rev. 0}

materials, install or construct modifications to liquid waste load-out system for truck tanker load-out. Although the existing entrance area is deemed adequate for backing tank trucks into 340-B East, detailed engineering preparations may determine that added pavement and/or fencing modifications may be necessary. Conduct radiological survey of the 340-B East work area. Post radiological conditions as required by HSRCM-1 (Hanford 1997).

\section{Schedule for Task Package 4.0}

The 340-B East liquid waste load-out modification tasks are scheduled for completion in the first quarter of FY00. This modification may be required earlier, if RLW needing shipment is acquired. Flushing and decon activities should be completed before the existing load-out capabilities are inactivated, otherwise the modifications may need to be completed under a 90-day waste accumulation clock. The estimated duration of work is identified on the detailed schedule attached as Appendix D. [It may be noted that while the tasks grouped under 4.0 all relate to the $340-B$ East Bldg., the sub-tasks are spread out in time due both to the nature of activities that occur in that area and an attempt to coordinate with other liquid waste producing tasks to maximize the efficiency of sample \& shipment events. The imminent loss of rail service pushed subtask 4.1 to the fore, due to the need to accommodate the task 7.1 shipment (possible RPS related waste, should it arise, could accelerate this need even more). The accelerated timing for the line flush under 4.2 is part of the waste shipment coordination intent.] Cost estimates, including materials and proposed team members, are attached as Appendix B.

\section{TASK PACKAGE 5.0: $\quad$ 340-A BUILDING DEACTIVATION}

\section{Background for Task Package $\mathbf{5 . 0}$}

The 340-A Building sits partially below grade and houses six $30-\mathrm{kL}(8,000$-gal) stainless steel tanks within a concrete berm. During routine operations these tanks are used as backup storage for the Vault tanks. Activities conducted in FY98 include tank sparging to eliminate sediment buildup inside the tanks. Cost, schedule, and work breakdown structure are based on obtaining a clean surface determination for the internal surfaces of the six tanks and that there is no TSCA impact relative to the existing tank liquids. If a clean surface determination cannot be obtained, the 340-A building will be dismantled and the tanks will be removed and transported to a TSD facility for final disposition.

\section{Scope of Task Package 5.0}

- Removing tank heels, cleaning tanks and related piping,

- Isolate tanks by blanking drain and vent lines,

- Remove, fix, or contain removable radioactive contamination,

- Remove unattached materials and equipment,

- Conduct radiological survey and post conditions, 
- Conduct safety evaluation and post hazards,

- Prepare building for interim monitoring (isolate pathways, access control, isolate utilities), and

- Document activities and place in central turnover package file.

\section{Approach for Task Package 5.0}

Remove all unattached materials and equipment. Decontaminate building interior to facilitate tank systems deactivation. Clean and flush tank heels to Vault tanks. Disconnect tank discharge and vent lines. Clean tank drain line to Vault tanks and sump drain line with high pressure nozzle spray system and inspect with video camera. Package tank interconnecting piping for transportation to TSD unit for treatment and disposal. Conduct radiological survey of the building interior and post conditions. Seal building penetrations and openings to prevent contamination migration and vermin intrusion. Isolate building electrical power, except to lighting and outlets needed for surveillance. Implement access control requirements and initiate interim monitoring program.

\section{Schedule for Task Package 5.0}

The 340-A Building stabilization activities are scheduled for completion in FY00. The scope of activities identified are based on regulatory agreement that the 340-A tanks meet alternate debris standard criteria and will remain in place. The estimated duration of work is identified on the detailed schedule attached as Appendix D. Cost estimates, including materials and proposed team members, are attached as Appendix B.

\section{TASK PACKAGE 6.0: $\quad 340$ VAULT AND VALVE PIT DECONTAMINATION}

\section{Background for Task Package 6.0}

The 340 Vault is an underground, reinforced concrete structure containing two stainless steel tanks and associated pumps, valving and piping. The valve pit is integral to the vault, though both have separate access locations. During routine operations, RLWS wastes routed to the Vault tanks are sampled and discharged to rail tank car via the 340-B East load-out station. The Vault and tanks are serviced by a common ventilation system, K1. Phase I activities are intended to prepare the Vault and tanks for closure activities scheduled for Phase II. Removing or fixing contamination in the vault should allow for the initial coverblock removal in Phase II to occur prior to erection of the greenhouse needed for disconnecting piping.

\section{Scope of Task Package 6.0}

- Decontaminate and stabilize Vault and Valve Pit surfaces;

- Decontaminate RLWS piping between 340-B Load-out and Vault tanks;

- Minimize tank content residuals. 
- Install and later dismantle greenhouse and exhaust filter unit;

- Downgrade K1 ventilation system, remove HEPA filters, and seal K1 duct openings;

- Isolate tanks and structure penetrations in preparation for Phase II activities;

- Conduct safety evaluation and radiological survey and post hazards; and

- Document activities and place in central turnover package file.

\section{Approach for Task Package 6.0}

The Vault interior surfaces will be decontaminated with conventional techniques and methods (washing, rinsing and wiping). Rinse liquids will be collected in the sump and pumped into the vault tanks. These solutions may be pre-filtered (with solids drummed for disposal) to preclude pluggage of the waste transporter, or the solids could be left in the tanks for eventual Phase II processing at the TSD facility. Residual contamination, if any, will be coated in place. Decontamination is intended to eliminate and fix removable contamination so that the operation of the $\mathrm{K} 1$ stack is no longer required, and, as noted under Background, to facilitate initial vault access during Phase II tank retrieval and vault scabbling tasks. It is possible that there will be a need for continued operation of the $\mathrm{K} 1$ system during Phase II as a minor stack. The option of mothballing part or all of this filtration exhaust system for possible use during Phase II tank removal and vault decon work will also be considered prior to taking any non-reversible deactivation steps. The RLWS fill and return lines between the vault tanks and the 340-B load-out will be decontaminated using high pressure nozzle spray system, followed by inspection with video camera. The high pressure spray liquids will drain back to the vault tanks. The remaining liquid in the vault tanks will then be pumped via an alternate path into a truck tank trailer for shipment to the designated TSD facility in the 200 Area. There may be alternatives such as leaving a heel in the tank to either evaporate, if $\mathrm{K} 1$ ventilation is maintained, and/or for co-shipment within the tanks to the TSD during Phase II. A greenhouse with portable exhaust filter unit will be installed over the K1 HEPA filters to facilitate their removal. All duct openings and the stack outlet will be sealed to prevent contamination migration. A safety evaluation and radiological survey will be conducted and the all hazards posted. The vault will be locked and interim monitoring will be initiated and remain in effect until Phase 11 of 340 Complex deactivation. To this end, the sump leak detector will be operationally retained.

\section{Schedule for Task Package 6.0}

The Vault and Valve Pit stabilization activities are scheduled for completion in FY01. The estimated duration of work is identified on the detailed schedule attached as Appendix D. Cost estimates, including materials and proposed team members, are attached as Appendix B. 


\section{TASK PACKAGE 7.0: LIQUID WASTE SHIPMENTS}

\section{Background for Task Package 7.0}

Phase I activities will involve rigorous RLWS system cleaning operations along with managing and shiping the accumulated liquid waste. Due to the shutdown of the Hanford rail system at the end of FY98, all liquid waste shipments will be made by truck tankers.

\section{Scope of Task Package 7.0}

- FY99 Shipments,

- FY00 Shipments, and

- FY01 Shipments.

\section{Approach for Task Package 7.0}

Liquid waste shipments will be managed and performed as all previous shipments except shipments will be made using truck tank trailers instead of rail cars. The number of estimated trips is predicated upon use of the 4.0-kL (approximately 1,060-gal) capacity French-made LR56 shielded cask truck (Lockheed 1996). In reality, depending upon the level of contamination in the waste solutions, larger 18.9-kL $(5,000-$ gal), non-shielded tank trucks may be usable. Using the vault tanks for staging RLW minimizes the number of expensive (approximately $\$ 25,000$ per suite) sample analyses required for shipments to the 200 Area receivers, since multiple trips could be made from a single, characterized tank. Waste generating tasks were grouped when feasible, to attempt to work within the 90-day waste accumulation clock for which a possible relief is discussed in Section 1.5 .

\section{Schedule for Task Package 7.0}

A total of four shipments are planned for $\mathrm{FY} 99$ and include liquid waste generated during the RLWS piping decontamination, 340 Decon Area decontamination, and 340-B load-out system initial flush. FYOO shipments will be the most extensive and involve approximately 24 shipments generated from $340-A$ tank decontamination. Final liquid waste shipments are scheduled for FY01 and comprise the remnants in the vault tanks, 340-B load-out piping cleaning solutions and the vault interior decontamination solutions. The estimated duration of work is identified on the detailed schedule attached as Appendix D. Cost estimates, including materials and proposed team members, are attached as Appendix B. Note that costs for samples identified under this task are slightly higher than for those indicated elsewhere. The $\$ 25,000$ reflects currently mandated analyses required by LMHC for acceptance of RLW; whereas sampling for other purposes (such as designation and ALARA input) is expected, (subject to later detailed planning and negotiations) to only involve a subset of the shipment suite. 
HNF-2230 Rev. 0

This page intentionally without substantive content. 
APPENDIX D - DETAILED SCHEDULE

\begin{tabular}{|c|c|c|c|c|c|c|c|c|}
\hline & & & & & FY98 & FY99 & FYOO & FY01 \\
\hline ID & TASK NAME & DUR. & START & FINISH & \begin{tabular}{|l|l|l|l|} 
Jun & Jul & Aug & Sep \\
\end{tabular} & \begin{tabular}{|l|l|l|l|l|l|l|l|l|l|} 
Oct & Nov & Dec & Jan & Feb & Mar & Apr & Ma & Jun & Jul \\
\end{tabular} & \begin{tabular}{|l|l|l|l|l|l|l|l|l|l|l|l|} 
Oct & Nov & Dec & Jan & Feb & Mar & Apr & Ma & Jun & Jul & Aug & Sep \\
\end{tabular} & \begin{tabular}{|l|l|l|l|l|l|l|l|l|l|l|} 
OCt & Nov & Dec & Jan & Feb & Mar & Apr & Ma & Jun & Jul & Aug \\
\end{tabular} \\
\hline 1.0 & ADMIN/ ENGINEERING & $837 \mathrm{~d}$ & $7 / 16 / 98$ & 9/28/01 & & & & \\
\hline 1.1 & USQ Screening & $837 \mathrm{~d}$ & $7 / 16 / 98$ & $9 / 28 / 01$ & & & & \\
\hline 1.2 & Administrative Manuals & $837 d$ & $7 / 16 / 98$ & $9 / 28 / 01$ & & & & \\
\hline 1.3 & Establish Turn-Over Pkg. (TOP) File & 120d & 7/30/98 & $1 / 13 / 99$ & 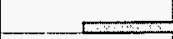 & & & \\
\hline 1.4 & Transporter Approvals & $143 \mathrm{~d}$ & 7/30/98 & $2 / 15 / 99$ & $=$ & & & \\
\hline 1.5 & ISB Revision & $175 \mathrm{~d}$ & $8 / 3 / 98$ & $4 / 2 / 99$ & & 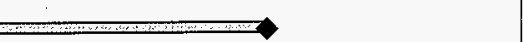 & & \\
\hline 1.6 & Revise FEMP & $90 \mathrm{~d}$ & $3 / 1 / 99$ & $7 / 2 / 99$ & & 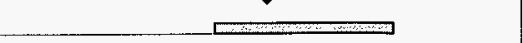 & & \\
\hline 1.7 & Revise CSER & $90 \mathrm{~d}$ & $7 / 7 / 99$ & $11 / 9 / 99$ & & & 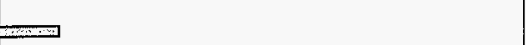 & \\
\hline 1.8 & Prepare Interim Monitoring Plan & $130 \mathrm{~d}$ & $10 / 2 / 00$ & $3 / 30 / 01$ & & & & 四 \\
\hline 1.9 & Prepare NOCs Vault Cleanout & 120d & $1 / 20 / 00$ & $6 / 9 / 00$ & & & 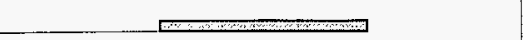 & \\
\hline 1.10 & Deactivation FHA & $30 \mathrm{~d}$ & $5 / 1 / 01$ & $6 / 11 / 01$ & & & & $\ldots$ \\
\hline 1.11 & ISB Revision (Second) & $50 \mathrm{~d}$ & $5 / 15 / 01$ & $7 / 23 / 01$ & & & & $\Longrightarrow$ \\
\hline 1.12 & Reg. Status Eval. Task 2.0 & $88 \mathrm{~d}$ & $6 / 1 / 99$ & $9 / 30 / 99$ & & & & \\
\hline 1.13 & Reg. Status Eval. Task 3.0 & $60 \mathrm{~d}$ & $10 / 1 / 99$ & $12 / 23 / 00$ & & & & \\
\hline 1.14 & Reg. Status Eval. Task 5.0 & $87 \mathrm{~d}$ & $6 / 1 / 00$ & $9 / 30 / 00$ & & & & \\
\hline 1.15 & Reg. Status Eval. Task 6.0 & 60d & $1 / 2 / 01$ & $3 / 26 / 01$ & & & & $=$ \\
\hline 2.0 & RLWS SYSTEM ISOLATION & $283 \mathrm{~d}$ & $9 / 1 / 98$ & 9/30/99 & & & & \\
\hline 2.1 & Reconfigure RPS Signals & $65 \mathrm{~d}$ & 9/1/98 & $11 / 30 / 98$ & & & & \\
\hline 2.2 & Cap/lsolate RLWS Piping & $65 \mathrm{~d}$ & $9 / 1 / 98$ & $11 / 30 / 98$ & $=$ & & & \\
\hline 2.3 & Install RPS Reroute & 45d & $12 / 1 / 98$ & $2 / 1 / 99$ & & 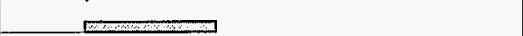 & & \\
\hline 2.4 & Decon. RLWS Piping & $64 \mathrm{~d}$ & $2 / 2 / 99$ & $4 / 30 / 99$ & & $=$ & & \\
\hline 2.5 & Inspect RLWS Piping & $80 \mathrm{~d}$ & $3 / 10 / 99$ & 6/29/99 & & 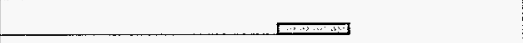 & & \\
\hline 2.6 & Stabilize Valve Boxes & 90d & $5 / 28 / 99$ & $9 / 30 / 99$ & & & & \\
\hline 2.7 & Prepare TOP ltems & $5 d$ & 9/24/99 & $9 / 30 / 99$ & & 四 & & \\
\hline 3.0 & 340 BLDG. DEACTIVATION & $143 \mathrm{~d}$ & $4 / 30 / 99$ & $11 / 16 / 99$ & & & & \\
\hline 3.1 & Decon. Hood and Sump & $21 d$ & $4 / 30 / 99$ & $5 / 28 / 99$ & & 正 & & \\
\hline 3.2 & Isolate Bldg. Piping & 44d & $6 / 1 / 99$ & $7 / 30 / 99$ & & $\Longrightarrow$ & & \\
\hline 3.3 & Housekeeping & $25 \mathrm{~d}$ & $8 / 2 / 99$ & $9 / 3 / 99$ & & ביב & & \\
\hline 3.4 & Decon/Stab. Decon Area & $25 \mathrm{~d}$ & $8 / 16 / 99$ & $9 / 17 / 99$ & & 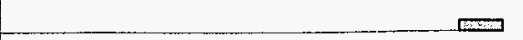 & & \\
\hline 3.5 & Conduct Rad. Survey & $15 \mathrm{~d}$ & $9 / 16 / 99$ & $10 / 6 / 99$ & & 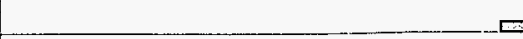 & & \\
\hline 3.6 & Isolate/Screen Pathways & $24 d$ & $10 / 7 / 99$ & $11 / 9 / 99$ & & & 舟 & \\
\hline 3.7 & Document TOP Items & 5d & $11 / 10 / 99$ & $11 / 16 / 99$ & & & 一ㅁ & \\
\hline & Deact. Decon Area & & & $11 / 16 / 99$ & & & & \\
\hline 4.0 & 340-BE STABILIZATION & $272 d$ & $11 / 30 / 98$ & $12 / 14 / 99$ & & & & \\
\hline 4.1 & Fabricate Jumpers for Load Out & $30 \mathrm{~d}$ & $11 / 30 / 98$ & $1 / 8 / 99$ & & & & \\
\hline
\end{tabular}




\begin{tabular}{|c|c|c|c|c|c|c|c|c|}
\hline & & & & & FY98 & FY99 & FYOO & FY01 \\
\hline $\mathrm{ID}$ & TASK NAME & DUR. & START & FINISH & Jun $\mid$ Jui| Aug Sep & 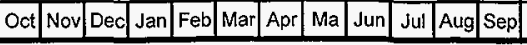 & 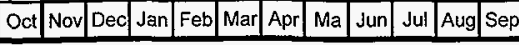 & 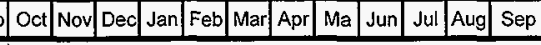 \\
\hline 4.2 & Flush System \& Drain Lines & $10 \mathrm{~d}$ & $5 / 28 / 99$ & $6 / 10 / 99$ & & $\square$ & & \\
\hline 4.3 & Decon Controlled Area & $15 \mathrm{~d}$ & $11 / 5 / 99$ & $11 / 25 / 99$ & & & $-\square$ & \\
\hline 4.4 & Conduct Rad. Survey & 15d & $11 / 26 / 99$ & $12 / 16 / 99$ & & & - & \\
\hline 4.5 & Document TOP Items & $5 \mathrm{~d}$ & $1218 / 99$ & $12 / 14 / 99$ & & & & \\
\hline & Stabilize 340-B East & & & $12 / 14 / 99$ & & & & \\
\hline 5.0 & 340-A BLDG DEACTIVATION & $194 \mathrm{~d}$ & $1 / 3 / 00$ & $9 / 28 / 00$ & & & & \\
\hline 5.1 & \begin{tabular}{|l} 
Decon Controlled Area \\
\end{tabular} & $33 \mathrm{~d}$ & $1 / 3 / 00$ & $2 / 16 / 00$ & & & 5 & \\
\hline 5.2 & Decon Tanks & 64d & $2 / 1100$ & 4/28/00 & & & - & \\
\hline 5.3 & Inspect Tanks & 44d & $3 / 27 / 100$ & $5 / 25 / 00$ & & & 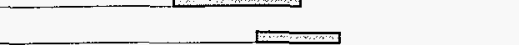 & \\
\hline 5.4 & Decon Piping & $22 \mathrm{~d}$ & $4 / 3 / 00$ & $5 / 2 / 00$ & & & \pm & \\
\hline 5.5 & Isolate Tanks/ Drains & $20 \mathrm{~d}$ & $5 / 25 / 00$ & $6 / 21100$ & & & & \\
\hline 5.6 & Housekeeping & $13 \mathrm{~d}$ & $6 / 22100$ & $7110 / 00$ & & & & \\
\hline 5.7 & Conduct Rad. Survey & $15 d$ & $7 / 111 / 00$ & $7 / 31 / 00$ & & & 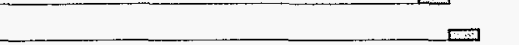 & \\
\hline 5.8 & Isolate/Screen Pathways & $10 \mathrm{~d}$ & $7 / 25 / 00$ & $8 / 7 / 00$ & & & 四 & \\
\hline 5.9 & De-energize Utilities & $35 \mathrm{~d}$ & $8 / 8 / 00$ & 9/25/00 & & & & \\
\hline 5.10 & Document TOP Items & 50 & $9 / 22 / 100$ & $9 / 28 / 00$ & & & 四 & \\
\hline & Deact. 340-A Building & & & $9 / 28 / 00$ & & & & \\
\hline 6.0 & 340 VAULT DECON & $230 \mathrm{~d}$ & 10/2/100 & $8 / 17 / 01$ & & & & \\
\hline 6.1 & Decon Vault Surfaces & $60 \mathrm{~d}$ & 10/2/00 & $12 / 22 / 00$ & & & & \\
\hline 6.2 & Decon 340-B Trans. Piping & $60 \mathrm{~d}$ & $11 / 20 / 00$ & $2 / 9 / 01$ & & & & \\
\hline 6.3 & Erect Grnhse//nstal Exhst. & $50 \mathrm{~d}$ & 2/12/101 & $4 / 20 / 01$ & & & & 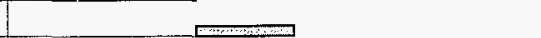 \\
\hline 6.4 & Remove HEPA Filters & 100 & $4 / 20 / 01$ & $5 / 3 / 01$ & & & & $\square$ \\
\hline 6.5 & Isolate K-1 Stack & $33 \mathrm{~d}$ & $4 / 30 / 01$ & 6/13/01 & & & & 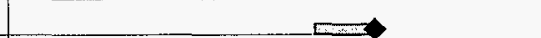 \\
\hline 6.6 & Remove Greenhouse/Exhauster & 10d & $6 / 18 / 01$ & $6 / 29 / 01$ & & & & 四 \\
\hline 6.7 & De-energ. Vault Systems & $15 \mathrm{~d}$ & $6 / 25 / 01$ & 7/13/01 & & & & $\Rightarrow$ \\
\hline 6.8 & \begin{tabular}{|l} 
Conduct Rad. Survey \\
\end{tabular} & $15 \mathrm{~d}$ & $7 / 9 / 01$ & $7 / 27 / 01$ & & & & 皿 \\
\hline 6.9 & Document TOP Items & 5d & $7 / 23 / 01$ & $8 / 17 / 01$ & & & & \\
\hline 7.0 & 340 LIQ. WASTE SHIPMENTS & 4960 & $5 / 3 / 99$ & 3/26/01 & & & & \\
\hline 7.1 & FY99 Shipment & $60 \mathrm{~d}$ & $5 / 3 / 99$ & $7 / 23 / 99$ & & 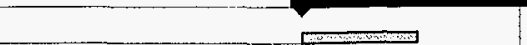 & & \\
\hline 7.2 & FYO0 Shipment & $120 \mathrm{~d}$ & $2 / 1 / 00$ & $7 / 17 / 00$ & & & & \\
\hline 7.3 & FY01 Shipment & $60 \mathrm{~d}$ & $1 / 2 / 01$ & 3/26/01 & & & & $=$ \\
\hline & $\begin{array}{l}\text { Project: } 340 \text { Deactivation - Pha } \\
\text { Daje: } 71198 \text { (Fiscal Years) }\end{array}$ & & & & & Milestone & & \\
\hline
\end{tabular}




\begin{tabular}{|c|c|c|c|c|}
\hline FACILITY / BUILDING & TASK TYPE & END POINT & NOTES & CLOSURE \\
\hline \multicolumn{5}{|l|}{340 Decon. Room } \\
\hline \multirow[t]{10}{*}{$\begin{array}{l}\text { Case 1: Internal Spaces, } \\
\text { Routine Access Required }\end{array}$} & TT-1 Hazard & $\begin{array}{l}\text { Remove unattached combustible materials to reduce the fire } \\
\text { hazard and meet the requirements of the deactivation FHA. }\end{array}$ & $\begin{array}{l}\text { Phase I - Verification to be completed by Facility } \\
\text { Safety }\end{array}$ & $\begin{array}{l}\text { OPN }-\ldots \\
\text { ENG }- \\
\text { DATE } \longrightarrow- \\
\text { REF }\end{array}$ \\
\hline & TT-1 Hazard & $\begin{array}{l}\text { Review remaining hazards and update the hazard } \\
\text { communication program (including sample hood and sink). }\end{array}$ & $\begin{array}{l}\text { Phase 1-Verification to be completed by Facility } \\
\text { Safety }\end{array}$ & $\begin{array}{l}\text { OPN } \\
\text { ENG }- \\
\text { DATE } \\
\text { REF } \\
\end{array}$ \\
\hline & TT-3 Contamination & $\begin{array}{l}\text { Include survey requirements as part of the turnover package to } \\
\text { verify containment of radioactive contamination. }\end{array}$ & $\begin{array}{l}\text { Survey requirements will be factored into Interim } \\
\text { Monitoring Plan for Phase I. This EPC will be re- } \\
\text { evaluated and addressed in S\&M Plan for Phase } \\
\text { II. (Rad Control) }\end{array}$ & $\begin{array}{l}\text { OPN } \\
\text { ENG } \\
\text { DATE } \\
\text { REF }\end{array}$ \\
\hline & TT-3 Contamination & Remove/ fix/ contain removable radioactive contamination. & See Task package 3.0, Subtask 3.5 & $\begin{array}{l}\text { OPN } \\
\text { ENG } \\
\text { DATE } \\
\text { REF } \\
\end{array}$ \\
\hline & TT-3 Contamination & $\begin{array}{l}\text { The } 340 \text { Building's Decon Room's general space removable } \\
\text { contamination level meets the definition of a CA as defined in } \\
\text { Hanford Site Radiological Control Manual (HSRCM-1), Chapter } \\
\text { 2, Rev } 2 \text { (Ref EPTI \#3). }\end{array}$ & See Task package 3.0 , Subtask 3.5 & $\begin{array}{l}\text { OPN } \\
\text { ENG } \\
\text { DATE } \\
\text { REF }\end{array}$ \\
\hline & TT-3 Contamination & $\begin{array}{l}\text { Post radiological conditions (including system(s) located in the } \\
\text { space) in accordance with Hanford Site Radiological Control } \\
\text { Manual (HSRCM-1), Chapter 2; Rev } 2 \text { (Ref EPTI \#3). }\end{array}$ & See Task package 3.0, Subtask 3.5 & $\begin{array}{l}\text { OPN } \\
\text { ENG } \\
\text { DATE } \\
\text { REF }\end{array}$ \\
\hline & TT-4 Waste & $\begin{array}{l}\text { Housekeep and remove unattached material, equipment and } \\
\text { office furniture. }\end{array}$ & See Task package 3.0, Subtask 3.3 & $\begin{array}{l}\text { OPN } \\
\text { ENG }- \\
\text { DATE } \\
\text { REF } \\
\end{array}$ \\
\hline & TT-4 Waste & Ensure sump is void of solution. & See Task package 3.0, Subtask 3.2 & $\begin{array}{l}\text { OPN } \\
\text { ENG } \\
\text { DATE } \\
\text { REF }\end{array}$ \\
\hline & TT-4 Waste & Ensure emergency lantern batteries are removed. & See Task package 3.0 , Subtask 3.3 & $\begin{array}{l}\text { OPN } \\
\text { ENG } \\
\text { DATE } \\
\text { REF } \\
\end{array}$ \\
\hline & TT-4 Waste & Remove accumulated radioactive, dangerous and mixed wastes. & See Task package 3.0 , Subtask 3.3 & $\begin{array}{l}\text { OPN } \\
\text { ENG }- \\
\text { DATE } \\
\text { REF }\end{array}$ \\
\hline
\end{tabular}




\begin{tabular}{|c|c|c|c|c|}
\hline FACILITY / BUILDING & TASK TYPE & END POINT & NOTES & CLOSURE \\
\hline \multicolumn{5}{|l|}{340 Decon. Room } \\
\hline \multirow[t]{6}{*}{$\begin{array}{l}\text { Case 1: Internal Spaces, } \\
\text { Routine Access Required }\end{array}$} & TT-5 Isolate \& Cont.. & $\begin{array}{l}\text { Isolate/ seal/ screen potential pathways to the environment to } \\
\text { inhibit vermin intrusion and contamination migration. }\end{array}$ & See Task package 3.0, Subtask 3.6 & $\begin{array}{l}\text { OPN } \\
\text { ENG }- \\
\text { DATE } \\
\text { REF } \\
\end{array}$ \\
\hline & TT-5 Isolate \& Cont.. & Isolate (close valves and remove handles) piping to/from sump. & See Task package 3.0, Subtask 3.2 & $\begin{array}{l}\text { OPN } \\
\text { ENG } \\
\text { DATE } \\
\text { REF }\end{array}$ \\
\hline & TT-8 Doc. \& Label & $\begin{array}{l}\text { Document identified area industrial hazards for inclusion in the } \\
\text { turnover package. }\end{array}$ & $\begin{array}{l}\text { Phase I - Verification to be completed by Facility } \\
\text { Safety }\end{array}$ & $\begin{array}{l}\text { OPN } \\
\text { ENG }- \\
\text { DATE } \\
\text { REF }\end{array}$ \\
\hline & TT-8 Doc. \& Label & Turnover package items: Deactivation work plans/packages. & $\begin{array}{l}\text { Documentation during Phase I will be maintained } \\
\text { in central project file and incorporated into final } \\
\text { Turnover Package. (Ref. Phase I Task 3.7) }\end{array}$ & $\begin{array}{l}\text { OPN } \\
\text { ENG } \\
\text { DATE } \\
\text { REF } \\
\end{array}$ \\
\hline & TT-8 Doc. \& Label & $\begin{array}{l}\text { Document space dose rates and contamination levels in the final } \\
\text { radiological survey report and map per Hanford Site Radiological } \\
\text { Control Manual (HSRCM-1), Chapter 5, Rev } 2 \text { (Ref EPT: \#4) for } \\
\text { inclusion in the turnover package. }\end{array}$ & See Task package 3.0, Subtask 3.5 & $\begin{array}{l}\text { OPN } \\
\text { ENG } \\
\text { DATE } \\
\text { REF } \\
\end{array}$ \\
\hline & TT-8 Doc. \& Label & $\begin{array}{l}\text { Document amount and location of remaining hazardous } \\
\text { substances/dangerous wastes (including systems) located in the } \\
\text { space. }\end{array}$ & $\begin{array}{l}\text { Phase I (This EPC will be re-evaluated for } \\
\text { Phase II.) End Point to be documented by } \\
\text { Facility Safety }\end{array}$ & $\begin{array}{l}\text { OPN } \\
\text { ENG } \\
\text { DATE } \\
\text { REF }\end{array}$ \\
\hline \multirow[t]{4}{*}{$\begin{array}{l}\text { Case 6: Systems } \\
\text { Abandoned in Place }\end{array}$} & TT-1 Hazard & $\begin{array}{l}\text { Drain/ vacate contents and isolate (close valves) utility feeder to } \\
\text { hoods. }\end{array}$ & See Task package 3.0, Subtask 3.2 & $\begin{array}{l}\text { OPN } \\
\text { ENG } \square \\
\text { DATE } \\
\text { REF } \\
\end{array}$ \\
\hline & TT-3 Contamination & Remove/ fix/ contain removable radioactive contamination. & See Task package 3.0, Subtask 3.4 & $\begin{array}{l}\text { OPN } \\
\text { ENG } \\
\text { DATE } \\
\text { REF } \\
\end{array}$ \\
\hline & TT-4 Waste & $\begin{array}{l}\text { Remove accumulated radioactive, dangerous, and mixed } \\
\text { wastes. }\end{array}$ & See Task package 3.0, Subtask 3.3 & $\begin{array}{l}\text { OPN } \\
\text { ENG } \\
\text { DATE } \\
\text { REF }\end{array}$ \\
\hline & TT-5 isolate \& Cont.. & Isolate /seal drains. & See Task package 3.0, Subtask 3.2 & $\begin{array}{l}\text { OPN } \\
\text { ENG } \\
\text { DATE } \\
\text { REF }\end{array}$ \\
\hline
\end{tabular}




\begin{tabular}{|c|c|c|c|c|}
\hline FACILITY / BUILDING & TASK TYPE & END POINT & NOTES & CLOSURE \\
\hline \multicolumn{5}{|l|}{340 Decon. Room } \\
\hline $\begin{array}{l}\text { Case 6: Systems } \\
\text { Abandoned in Place }\end{array}$ & TT-8 Doc. \& Label & Turnover package items: Deactivation work plans/ packages. & $\begin{array}{l}\text { Documentation during Phase I will be maintained } \\
\text { in central project file and incorporated into final } \\
\text { Turnover Package. (Ref. Phase I Task 3.7) } \\
\end{array}$ & $\begin{array}{l}\text { OPN } \\
\text { ENG }-- \\
\text { DATE }- \\
\text { REF }\end{array}$ \\
\hline \multicolumn{5}{|l|}{ Vault \& Valve Pit } \\
\hline \multirow[t]{9}{*}{$\begin{array}{l}\text { Case 2: Intern. Spaces, } \\
\text { No Rout. Acc. Required }\end{array}$} & TT-1 Hazard & $\begin{array}{l}\text { Remove unattached combustible materials to reduce the fire } \\
\text { hazard and meet the requirements of the deactivation FHA. }\end{array}$ & See Task package 6.0, Subtask 6.6 & $\begin{array}{l}\text { OPN } \\
\text { ENG }- \\
\text { DATE }- \\
\text { REF }\end{array}$ \\
\hline & TT-1 Hazard & Ensure valve pit is properly posted as a confined space. & See Task package 6.0, Subtask 6.9 & $\begin{array}{l}\text { OPN } \\
\text { ENG } \\
\text { DATE_- } \\
\text { REF } \\
\end{array}$ \\
\hline & TT-1 Waste & Ensure vault is properly posted as a confined space. & See Task package 6.0, Subtask 6.8 & $\begin{array}{l}\text { OPN } \\
\text { ENG }- \\
\text { DATE } \\
\text { REF } \\
\end{array}$ \\
\hline & TT-2 Radiation Fields & $\begin{array}{l}\text { Post radiological conditions (including system(s) located in the } \\
\text { space) in accordance with Hanford Site Radiological Control } \\
\text { Manual (HSRCM-1), Chapter 2, Rev } 2 \text { (Ref EPTI \#3). }\end{array}$ & See Task package 6.0 , Subtask 6.8 & $\begin{array}{l}\text { OPN } \\
\text { ENG } \\
\text { DATE } \\
\text { REF }\end{array}$ \\
\hline & TT-3 Contamination & $\begin{array}{l}\text { Post radiological conditions (including system(s) located in the } \\
\text { space) in accordance with Hanford Site Radiological Control } \\
\text { Manual (HSRCM-1), Chapter 2, Rev } 2 \text { (Ref EPTI \#3). }\end{array}$ & See Task package 6.0, Subtask 6.8 & $\begin{array}{l}\text { OPN } \\
\text { ENG } \\
\text { DATE } \\
\text { REF }\end{array}$ \\
\hline & TT-3 Contamination & $\begin{array}{l}\text { The Vault Penthouse Room's general space removable } \\
\text { contamination level meets the definition of a CA as defined in } \\
\text { Hanford Site Radiological Control Manual (HSRCM-1), Chapter } \\
\text { 2, Rev. } 2 \text { (Ref EPTI \#3) }\end{array}$ & See Task package 6.0, Subtask 6.8 & $\begin{array}{l}\text { OPN } \\
\text { ENG } \\
\text { DATE - } \\
\text { REF }\end{array}$ \\
\hline & TT-4 Waste & Housekeep and remove unattached materials/equipment. & See Task package 6.0, Subtask 6.6 & $\begin{array}{l}\text { OPN } \\
\text { ENG } \\
\text { DATE } \\
\text { REF }\end{array}$ \\
\hline & TT-4 Waste & Remove oil from equipment including valve pit. & See Task package 6.0, Subtask 6.1 & $\begin{array}{l}\text { OPN } \\
\text { ENG } \\
\text { DATE_- } \\
\text { REF }\end{array}$ \\
\hline & TT-4 Waste & $\begin{array}{l}\text { Remove accumulated radioactive, dangerous, and mixed } \\
\text { wastes. }\end{array}$ & See Task package 6.0 , Subtask 6.1 & $\begin{array}{l}\text { ENG }- \\
\text { DATE } \\
\text { REF }\end{array}$ \\
\hline
\end{tabular}




\begin{tabular}{|c|c|c|c|c|}
\hline FACILITY / BUIL.DING & TASK TYPE & END POINT & NOTES & CLOSURE \\
\hline \multicolumn{5}{|l|}{ Vault \& Valve Pit } \\
\hline \multirow[t]{3}{*}{$\begin{array}{l}\text { Case 2: Intern. Spaces, } \\
\text { No Rout. Acc. Required }\end{array}$} & TT-6 Monitor \& Control & Provide liquid monitoring for vault sump. & See Task package 6.0 , Subtask 6.7 & $\begin{array}{l}\text { OPN } \\
\text { ENG_- } \\
\text { DATE } \\
\text { REF }\end{array}$ \\
\hline & TT-8 Doc. \& Label & $\begin{array}{l}\text { Document amount and location of remaining hazardous } \\
\text { substances/dangerous wastes (including systems) located in the } \\
\text { space. }\end{array}$ & $\begin{array}{l}\text { Phase I - Verification to be completed by Facility } \\
\text { Safety }\end{array}$ & $\begin{array}{l}\text { OPN } \\
\text { ENG } \\
\text { DATE } \\
\text { REF }\end{array}$ \\
\hline & TT-8 Doc. \& Label & $\begin{array}{l}\text { Turnover package items: Deactivation work plans/ packages. } \\
\text { Description /photos of Case } 2 \text { spaces. }\end{array}$ & $\begin{array}{l}\text { Documentation during Phase I will be maintained } \\
\text { in central project file and incorporated into final } \\
\text { Turnover Package. (Ref. Task package } 6.0 \text {, } \\
\text { Subtask 6.9) }\end{array}$ & $\begin{array}{l}\text { OPN } \\
\text { ENG } \\
\text { DATE } \\
\text { REF }\end{array}$ \\
\hline \multicolumn{5}{|l|}{ 340-A Building } \\
\hline \multirow[t]{6}{*}{$\begin{array}{l}\text { Case 1: Internal Spaces, } \\
\text { Routine Access Required }\end{array}$} & TT-1 Hazards & $\begin{array}{l}\text { Remove unattached combustible materials to reduce the fire } \\
\text { hazard and meet the requirements of the deactivation FHA. }\end{array}$ & $\begin{array}{l}\text { Phase I - Verification to be completed by Facility } \\
\text { Safety }\end{array}$ & $\begin{array}{l}\text { OPN } \\
\text { ENG } \\
\text { DATE } \\
\text { REF }\end{array}$ \\
\hline & TT-1 Hazards & Ensure vessels are properly posted as confined spaces. & See Task package 5.0 , Subtask 5.5 & $\begin{array}{l}\text { OPN } \\
\text { ENG } \\
\text { DATE } \\
\text { REF }\end{array}$ \\
\hline & TT-1 Hazards & $\begin{array}{l}\text { Review remaining hazards and update the hazard } \\
\text { communications program (including vessels). }\end{array}$ & $\begin{array}{l}\text { Phase I - Verification to be completed by Facility } \\
\text { Safety }\end{array}$ & $\begin{array}{l}\text { OPN } \\
\text { ENG } \\
\text { DATE } \\
\text { REF }\end{array}$ \\
\hline & TT-2 Rad. Fields & $\begin{array}{l}\text { Post radiological conditions (including systems(s) located in the } \\
\text { space) in accordance with Hanford Site Radiological Control } \\
\text { Manual (HSRCM-1), Chapter 2, Rev } 2 \text { (Ref EPTI \#3). }\end{array}$ & See Task package 5.0, Subtask 5.7 & $\begin{array}{l}\text { OPN } \\
\text { ENG } \\
\text { DATE } \\
\text { REF }\end{array}$ \\
\hline & TT-3 Contamination & $\begin{array}{l}\text { The 340-A Building's general space removable contamination } \\
\text { level meets the definition of a CA as defined in Hanford Site } \\
\text { Radiological Control Manual (HSRCM-1), Chapter 2, Rev. } 2 \text { (Ref } \\
\text { EPTI \#3) }\end{array}$ & See Task package 5.0, Subtask 5.7 & $\begin{array}{l}\text { OPN } \\
\text { ENG } \\
\text { DATE } \\
\text { REF }\end{array}$ \\
\hline & TT-3 Contamination & $\begin{array}{l}\text { Remove/ fix/ contain radioactive contamination to inhibit } \\
\text { migration. }\end{array}$ & See Task package 5.0, Subtask 5.1 & $\begin{array}{l}\text { OPN } \\
\text { ENG } \\
\text { DATE } \\
\text { REF } \\
\end{array}$ \\
\hline
\end{tabular}




\begin{tabular}{|c|c|c|c|c|}
\hline FACILITY / BUILDING & TASK TYPE & END POINT & NOTES & CLOSURE \\
\hline \multicolumn{5}{|l|}{ 340-A Building } \\
\hline \multirow[t]{7}{*}{$\begin{array}{l}\text { Case 1: Internal Spaces, } \\
\text { Routine Access Required }\end{array}$} & TT-3 Contamination & $\begin{array}{l}\text { Post radiological conditions (including system(s) located in the } \\
\text { space) in accordance with Hanford Site Radiological Control } \\
\text { Manual (HSRCM-1), Chapter 2, Rev } 2 \text { (Ref EPTI \#3). }\end{array}$ & See Task package 5.0, Subtask 5.7 & $\begin{array}{l}\text { OPN } \\
\text { ENG } \\
\text { DATE } \\
\text { REF }\end{array}$ \\
\hline & TT-4 Waste & $\begin{array}{l}\text { Housekeep and remove unattached materials, equipment, and } \\
\text { office furniture. }\end{array}$ & See Task package 5.0, Subtask 5.6 & $\begin{array}{l}\text { OPN } \\
\text { ENG } \\
\text { DATE } \\
\text { REF }\end{array}$ \\
\hline & TT-4 Waste & Ensure sump is void of liquid. & See Task package 5.0, Subtask 5.1 & $\begin{array}{l}\text { OPN } \\
\text { ENG } \\
\text { DATE } \\
\text { REF } \\
\end{array}$ \\
\hline & TT-4 Waste & $\begin{array}{l}\text { Remove accumulated radioactive, dangerous, and mixed } \\
\text { wastes. }\end{array}$ & See Task package 5.0, Subtask 5.1 & $\begin{array}{l}\text { OPN } \\
\text { ENG } \\
\text { DATE } \\
\text { REF }\end{array}$ \\
\hline & TT-8 Doc. \& Label & $\begin{array}{l}\text { Document identified area industrial hazards for inclusion in the } \\
\text { turnover package. }\end{array}$ & $\begin{array}{l}\text { Phase I - Verification to be completed by Facility } \\
\text { Safety }\end{array}$ & $\begin{array}{l}\text { OPN } \\
\text { ENG } \\
\text { DATE } \\
\text { REF }\end{array}$ \\
\hline & TT-8 Doc. \& Label & $\begin{array}{l}\text { Document amount and location of remaining hazardous } \\
\text { substances/ dangerous wastes (including system(s) located in } \\
\text { the spaces). }\end{array}$ & $\begin{array}{l}\text { Phase I - Verification to be completed by Facility } \\
\text { Safety }\end{array}$ & $\begin{array}{l}\text { OPN } \\
\text { ENG } \\
\text { DATE } \\
\text { REF }\end{array}$ \\
\hline & TT-1 Hazard & $\begin{array}{l}\text { Perform zero energy check to verify electrical Isolation } \\
\text { (Excluding lighting) }\end{array}$ & See Task package 5.0, Subtask 5.9 & $\begin{array}{l}\text { OPN } \\
\text { ENG } \\
\text { DATE } \\
\text { REF }\end{array}$ \\
\hline \multicolumn{5}{|l|}{ 340-B East } \\
\hline \multirow[t]{3}{*}{$\begin{array}{l}\text { Case 1: Internal Spaces, } \\
\text { Routine Access Required }\end{array}$} & TT-1 Hazards & $\begin{array}{l}\text { Remove unattached combustible materials to reduce the fire } \\
\text { hazard and meet the requirements of the deactivation FHA. }\end{array}$ & $\begin{array}{l}\text { Phase I - Verification to be completed by Facility } \\
\text { Safety }\end{array}$ & $\begin{array}{l}\text { OPN } \\
\text { ENG } \\
\text { DATE } \\
\text { REF } \\
\end{array}$ \\
\hline & TT- 1 Hazards & $\begin{array}{l}\text { Review remaining hazards and update the hazard } \\
\text { communications program (including vessels). }\end{array}$ & $\begin{array}{l}\text { Phase I - Verification to be completed by Facility } \\
\text { Safety }\end{array}$ & $\begin{array}{l}\text { OPN } \\
\text { ENG } \\
\text { DATE } \\
\text { REF }\end{array}$ \\
\hline & TT-2 Rad. Fields & $\begin{array}{l}\text { The 340-B Load-out Area's general space dose rate meets the } \\
\text { definition of a RA ( }>5 \text { mrem/hr and , = } 100 \text { mrem/hr at } 30 \mathrm{~cm} \text { ) as. } \\
\text { defined in Hanford Site Radiological Control Manual (HSRCM-1), } \\
\text { Chapter 2, Rev. } 2 \text { (Ref EPTI \#3) }\end{array}$ & See Task package 4.0, Subtask 4.4 & $\begin{array}{l}\text { OPN } \\
\text { ENG } \\
\text { DATE } \\
\text { REF }\end{array}$ \\
\hline
\end{tabular}




\begin{tabular}{|c|c|c|c|c|}
\hline FACILITY / BUILDING & TASK TYPE & END POINT & NOTES & CLOSURE \\
\hline \multicolumn{5}{|l|}{ 340-B East } \\
\hline \multirow[t]{10}{*}{$\begin{array}{l}\text { Case 1: Internal Spaces, } \\
\text { Routine Access Required }\end{array}$} & TT-2 Rad. Fields & $\begin{array}{l}\text { Post radiological conditions (including systems(s) located in the } \\
\text { space) in accordance with Hanford Site Radjological Control } \\
\text { Manual (HSRCM-1), Chapter 2, Rev } 2 \text { (Ref EPTI \#3). }\end{array}$ & See Task package 4.0, Subtask 4.4 & $\begin{array}{l}\text { OPN } \\
\text { ENG } \\
\text { DATE } \\
\text { REF }\end{array}$ \\
\hline & TT-3 Contamination & $\begin{array}{l}\text { The 340-B Load-out Area's general space removable } \\
\text { contamination level meets the definition of a CA as defined in } \\
\text { Hanford Site Radiological Control Manual (HSRCM-1), Chapter } \\
\text { 2, Rev. } 2 \text { (Ref EPTI \#3) }\end{array}$ & See Task package 4.0, Subtask 4.4 & $\begin{array}{l}\text { OPN } \\
\text { ENG } \\
\text { DATE } \\
\text { REF }\end{array}$ \\
\hline & TT-3 Contamination & $\begin{array}{l}\text { Remove/ fix/ contain radioactive contamination to inhibit } \\
\text { migration. }\end{array}$ & See Task package 4.0 , Subtask 4.3 & $\begin{array}{l}\text { OPN } \\
\text { ENG } \\
\text { DATE } \\
\text { REF }\end{array}$ \\
\hline & TT-3 Contamination & $\begin{array}{l}\text { Post radiological conditions (including system(s) located in the } \\
\text { space) in accordance with Hanford Site Radiological Control } \\
\text { Manual (HSRCM-1), Chapter 2, Rev } 2 \text { (Ref EPTI \#3). }\end{array}$ & See Task package 4.0 , Subtask 4.4 & $\begin{array}{l}\text { OPN } \\
\text { ENG } \\
\text { DATE } \\
\text { REF }\end{array}$ \\
\hline & TT-4 Waste & Housekeep and remove unattached material/ equipment. & See Task package 4.0, Subtask 4.3 & $\begin{array}{l}\text { OPN } \\
\text { ENG } \\
\text { DATE } \\
\text { REF } \\
\end{array}$ \\
\hline & TT-4 Waste & $\begin{array}{l}\text { Remove accumulated radioactive, dangerous, and mixed } \\
\text { wastes. }\end{array}$ & See Task package 4.0, Subtask 4.3 & $\begin{array}{l}\text { OPN } \\
\text { ENG } \\
\text { DATE } \\
\text { REF }\end{array}$ \\
\hline & TT-8 Doc. \& Label & $\begin{array}{l}\text { Document identified area industrial hazards for inclusion in the } \\
\text { turnover package. }\end{array}$ & $\begin{array}{l}\text { Phase 1 - Verification to be completed by Facility } \\
\text { Safety }\end{array}$ & $\begin{array}{l}\text { OPN } \\
\text { ENG } \\
\text { DATE } \\
\text { REF }\end{array}$ \\
\hline & TT-8 Doc. \& Label & Turnover package items: Deactivation work plans/ packages. & $\begin{array}{l}\text { Documentation during Phase I will be maintained } \\
\text { in central project file and incorporated into final } \\
\text { Turnover Package. (Ref. Task package } 4.0 \text {, } \\
\text { Șubtask 4.6.) }\end{array}$ & $\begin{array}{l}\text { OPN } \\
\text { ENG } \\
\text { DATE- } \\
\text { REF }\end{array}$ \\
\hline & TT-8 Doc. \& Label & $\begin{array}{l}\text { Document amount and location of remaining hazardous } \\
\text { substances/ dangerous wastes (including system(s) located in } \\
\text { the space). }\end{array}$ & $\begin{array}{l}\text { Phase I - Verification to be completed by Facility } \\
\text { Safety }\end{array}$ & $\begin{array}{l}\text { OPN } \\
\text { ENG } \\
\text { DATE } \\
\text { REF } \\
\end{array}$ \\
\hline & TT-8 Doc. \& Label & $\begin{array}{l}\text { Document space dose rates and contamination levels in the final } \\
\text { radiological survey report and map per Hanford Site Radiological } \\
\text { Control Manual (HSRCM-1), Chapter 5, Rev } 2 \text { (Ref EPTI \#4) for } \\
\text { inclusion in the turnover package. }\end{array}$ & See Task package 4.0, Subtask 4.4 & $\begin{array}{l}\text { OPN } \\
\text { ENG } \\
\text { DATE } \\
\text { REF }\end{array}$ \\
\hline
\end{tabular}




\begin{tabular}{|c|c|c|c|c|}
\hline FACILITY I BUILDING & TASK TYPE & END POINT & NOTES & CLOSURE \\
\hline \multicolumn{5}{|l|}{ HVAC, $\mathrm{K}-1$ Stack } \\
\hline \multirow[t]{5}{*}{$\begin{array}{l}\text { Case 6: Systems, } \\
\text { Abandoned In Place }\end{array}$} & TT-5 Isolate \& Cont.. & $\begin{array}{l}\text { Cap K-1 stack opening to inhibit contamination migration and } \\
\text { water/ vermin intrusion. }\end{array}$ & See Task package 6.0, Subtask 6.7 & $\begin{array}{l}\text { OPN } \\
\text { ENG }- \\
\text { DATE } \\
\text { REF }\end{array}$ \\
\hline & TT-5 Isolate \& Cont.. & $\begin{array}{l}\text { Remove } 340 \text { Vault } \mathrm{K}-1 \text { exhaust filters and isolate to inhibit } \\
\text { contamination migration. }\end{array}$ & See Task package 6.0, Subtask 6.4 & $\begin{array}{l}\text { OPN } \\
\text { ENG } \\
\text { DATE } \\
\text { REF }\end{array}$ \\
\hline & TT-5 Isolate \& Cont.. & $\begin{array}{l}\text { isolate/ seal main supply fan inlet to inhibit contamination } \\
\text { migration. }\end{array}$ & See Task package 6.0, Subtask 6.5 & $\begin{array}{l}\text { OPN } \\
\text { ENG } \\
\text { DATE } \\
\text { REF }\end{array}$ \\
\hline & TT-8 Doc. \& Label & Turnover package items: Deactivation work plans/packages. & $\begin{array}{l}\text { Documentation during Phase I will be maintained } \\
\text { in central project file and incorporated into final } \\
\text { Turnover Package. (Ref. Task package 6.0, } \\
\text { Subtask 6.9) }\end{array}$ & $\begin{array}{l}\text { OPN } \\
\text { ENG } \\
\text { DATE } \\
\text { REF }\end{array}$ \\
\hline & TT-8 Doc. \& Label & Document K-1 stack closure to DOH. & & $\begin{array}{l}\text { OPN } \\
\text { ENG } \\
\text { DATE } \\
\text { REF }\end{array}$ \\
\hline \multicolumn{5}{|l|}{ Vessels } \\
\hline \multirow[t]{5}{*}{$\begin{array}{l}\text { Case 6: Systems, } \\
\text { Abandoned.In Place }\end{array}$} & TT-3 Contamination & $\begin{array}{l}\text { Fix/ contain residual material in AGS \#1 to inhibit contamination } \\
\text { migration. }\end{array}$ & See Task package 5.0, Subtask 5.5 & $\begin{array}{l}\text { OPN } \\
\text { ENG } \\
\text { DATE } \\
\text { REF }\end{array}$ \\
\hline & TT-3 Contamination & $\begin{array}{l}\text { Fix/ contain residual material in AGS \#2 to inhibit contamination } \\
\text { migration. }\end{array}$ & See Task package 5.0, Subtask 5.5 & $\begin{array}{l}\text { OPN } \\
\text { ENG } \\
\text { DATE } \\
\text { REF } \\
\end{array}$ \\
\hline & $\mathrm{TT}-3$ Contamination & $\begin{array}{l}\text { Fix/ contain residual material in AGS \#3 to inhibit contamination } \\
\text { migration. }\end{array}$ & See Task package 5.0, Subtask 5.5 & $\begin{array}{l}\text { OPN } \\
\text { ENG } \\
\text { DATE } \\
\text { REF } \\
\end{array}$ \\
\hline & TT-3 Contamination & $\begin{array}{l}\text { Fix/ contain residual material in AGS \#4 to inhibit contamination } \\
\text { migration. }\end{array}$ & See Task package 5.0, Subtask 5.5 & $\begin{array}{l}\text { OPN } \\
\text { ENG } \\
\text { DATE } \\
\text { REF }\end{array}$ \\
\hline & TT-3 Contamination & $\begin{array}{l}\text { Fix/ contain residual material in AGS \#5 to inhibit contamination } \\
\text { migration. }\end{array}$ & See Task package 5.0, Subtask 5.5 & $\begin{array}{l}\text { OPN } \\
\text { ENG } \\
\text { DATE } \\
\text { REF }\end{array}$ \\
\hline
\end{tabular}




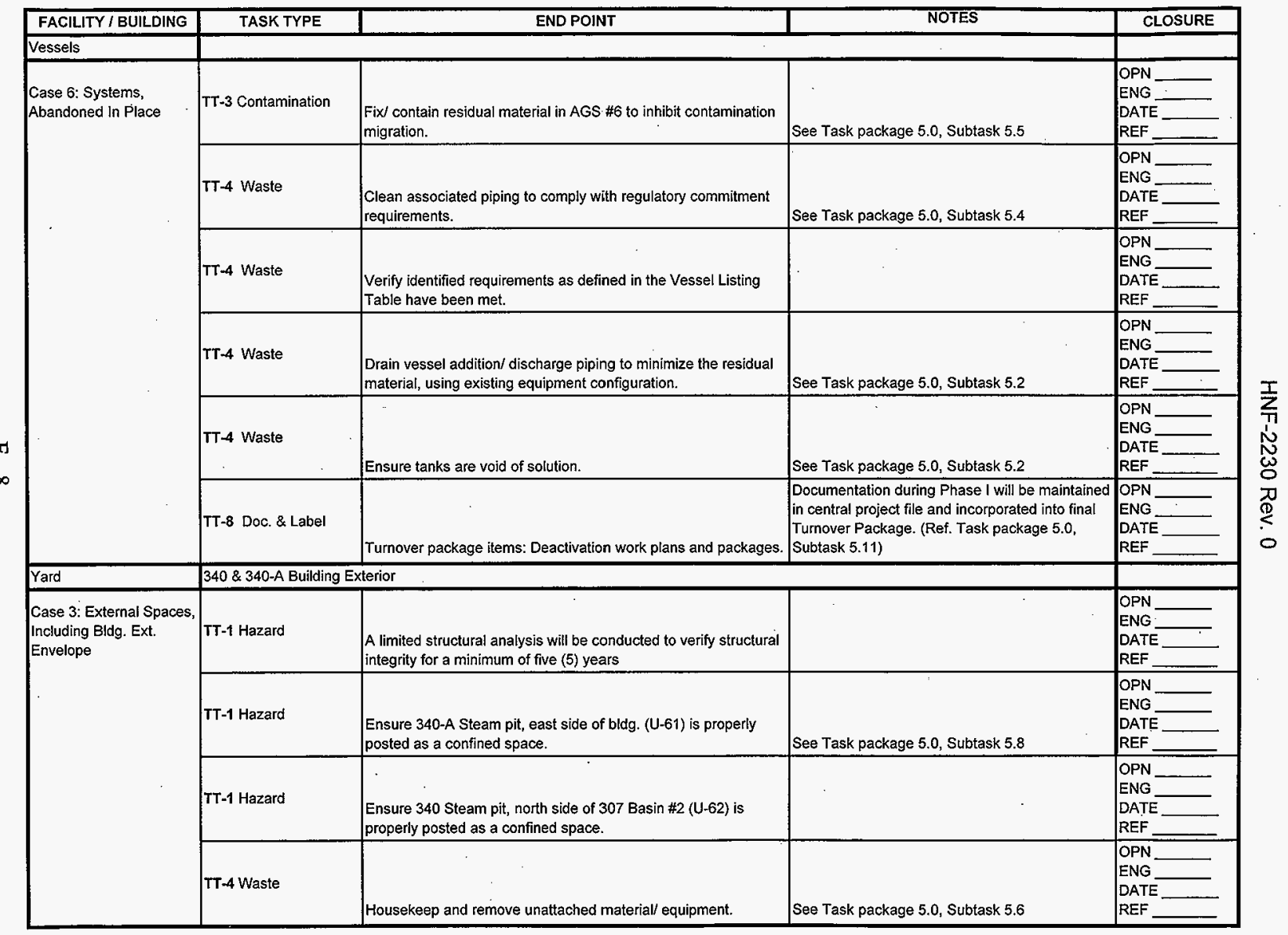




\begin{tabular}{|c|c|c|c|c|}
\hline FACILITY / BUILDING & TASK TYPE & END POINT & NOTES & CLOSURE \\
\hline Yard & \multicolumn{3}{|c|}{$340 \& 340-A$ Building Exterior } & \\
\hline \multirow[t]{10}{*}{$\begin{array}{l}\text { Case 3: External Spaces, } \\
\text { Including Bldg. Ext. } \\
\text { Envelope }\end{array}$} & TT-5 Isolate \& Contain & 340-A: Ensure exterior door seals are in proper working order. & See Task package 5.0, Subtask 5.8 & $\begin{array}{l}\text { OPN } \\
\text { ENG } \\
\text { DATE } \\
\text { REF }\end{array}$ \\
\hline & TT-5 Isolate \& Contain & $\begin{array}{l}\text { Isolate/ screen } 340-A \text { potential pathways from the environment to } \\
\text { inhibit vermin intrusion. }\end{array}$ & See Task package 5.0 , Subtask 5.8 & $\begin{array}{l}\text { OPN } \\
\text { ENG } \\
\text { DATE } \\
\text { REF }\end{array}$ \\
\hline & Tr-5 Isolate \& Contain & $\begin{array}{l}\text { 340-A: Place postings at entrances and lock doors to prevent } \\
\text { unintentional/ unauthorized access. }\end{array}$ & See Task package 5.0, Subtask 5.8 & $\begin{array}{l}\text { OPN } \\
\text { ENG } \\
\text { DATE } \\
\text { REF }\end{array}$ \\
\hline & TT-5 Isolate \& Contain & $\begin{array}{l}\text { Assess roof integrity for the prevention of in-leakage for a } \\
\text { minimum of five (5) years. }\end{array}$ & & $\begin{array}{l}\text { OPN } \\
\text { ENG } \\
\text { DATE } \\
\text { REF }\end{array}$ \\
\hline & TT.5 Isolate \& Contain & $\begin{array}{l}\text { 340-A: Label entrances stating all systems within are abandoned } \\
\text { in place. }\end{array}$ & See Task package 5.0, Subtask 5.8 & $\begin{array}{l}\text { OPN } \\
\text { ENG } \\
\text { DATE } \\
\text { REF } \\
\end{array}$ \\
\hline & TT-7 Refurb. or Install & $\begin{array}{l}\text { Refurbish } 340-A \text { Building as required by the structural and } \\
\text { integrity studies. }\end{array}$ & & $\begin{array}{l}\text { OPN } \\
\text { ENG } \\
\text { DATE } \\
\text { REF }\end{array}$ \\
\hline & TT-8 Doc. \& Label & $\begin{array}{l}\text { Document identified area industrial hazards for inclusion in the } \\
\text { turnover package. }\end{array}$ & $\begin{array}{l}\text { Phase I - Verification to be completed by Facility } \\
\text { Safety }\end{array}$ & $\begin{array}{l}\text { OPN } \\
\text { ENG } \\
\text { DATE } \\
\text { REF }\end{array}$ \\
\hline & TT-8 Doc. \& Label & $\begin{array}{l}\text { Verify ancillary building identifications are clearly posted on the } \\
\text { exterior of the building. }\end{array}$ & See Task package 5.0, Subtask 5.8 & $\begin{array}{l}\text { OPN } \\
\text { ENG } \\
\text { DATE } \\
\text { REF }\end{array}$ \\
\hline & TT-8 Doc. \& Label & Turnover package items: Deactivation work plans/ packages. & $\begin{array}{l}\text { Documentation during Phase I will be maintained } \\
\text { in central project file and incorporated into final } \\
\text { Turnover Package. (Ref. Task package 5.0, } \\
\text { Subtask 6.11) }\end{array}$ & $\begin{array}{l}\text { OPN } \\
\text { ENG } \\
\text { DATE } \\
\text { REF } \\
\end{array}$ \\
\hline & TT-8 Doc. \& Label & $\begin{array}{l}\text { Document amount and location of remaining hazardous } \\
\text { substances/dangerous wastes (including systems) located in the } \\
\text { space. }\end{array}$ & $\begin{array}{l}\text { Phase I - Verification to be completed by Facility } \\
\text { Safety }\end{array}$ & $\begin{array}{l}\text { OPN } \\
\text { ENG } \\
\text { DATE } \\
\text { REF } \\
\end{array}$ \\
\hline
\end{tabular}




\begin{tabular}{|c|c|c|c|c|}
\hline FACILITY / BUILDING & TASK TYPE & END POINT & NOTES & CLOSURE \\
\hline \multicolumn{5}{|l|}{ RIWS } \\
\hline \multirow[t]{6}{*}{$\begin{array}{l}\text { Case 6: Systems, } \\
\text { Abandoned In Place }\end{array}$} & TT-1 Hazard & Isolate/ blank line from 327 Building. & \multirow[b]{2}{*}{ See work package 2.0 , Subtask 2.2} & $\begin{array}{l}\text { OPN } \\
\text { ENG } \\
\text { DATE } \\
\text { REF }= \\
\end{array}$ \\
\hline & TT-1 Hazard & Isolate/_blank line from 326 Building. & & $\begin{array}{l}\text { OPN } \\
\text { ENG }- \\
\text { DATE } \\
\text { REF }=\end{array}$ \\
\hline & TT-1 Hazard & Isolate/ blank line from 325 Building. & See work package 2.0, Subtask 2.2 & $\begin{array}{l}\text { OPN } \\
\text { ENG } \\
\text { DATE } \\
\text { REF } \\
\end{array}$ \\
\hline & TT-1 Hazard & Isolate/ blank line from 324 Building. & See work package 2.0, Subtask 2.2 & $\begin{array}{l}\text { OPN } \\
\text { ENG } \\
\text { DATE } \\
\text { REF }=\end{array}$ \\
\hline & TT-1 Hazard & Isolate/ blank line from 329 Building. & See work package 2.0, Subtask 2.2 & $\begin{array}{l}\text { OPN } \\
\text { ENG } \\
\text { DATE } \\
\text { REF } \\
\end{array}$ \\
\hline & TT-8 Doc. \& Label & Turnover package items: Deactivation work plans/ packages. & $\begin{array}{l}\text { Documentation during Phase I will be maintained } \\
\text { in central project file and incorporated into final } \\
\text { Turnover Package. (Ret. Task package } 2.0, \\
\text { Subtask } 2.7 \text { ) }\end{array}$ & $\begin{array}{l}\text { OPN } \\
\text { ENG } \\
\text { DATE } \\
\text { REF }\end{array}$ \\
\hline
\end{tabular}




\section{HNF-2230 Rev. 0}

\section{APPENDIX F - FORMAL ENDPOINT CRITERIA DOCUMENT}

This Appendix $F$ is a placeholder for a later PMP revision, and will contain the final EPC to be developed negotiated with, and approved by, the ERC during Phase II (Task 1.2). The interim endpoint criteria (IEPC) in Appendix E should dovetail with this and the resulting IEPC closure signatures obtained during Phase I should facilitate final closure on the formal EPC. Also, a draft, complete set of EPC, that pertain to the entire 340 Complex prior to turnover at the end of Phase II have been prepared by the BWHC FASTER team, Section 1.4.15. This set of EPC were used to create Appendix E, and could serve as the starting point for producing the final, formal EPC Document. 
HNF-2230 Rev. 0

This page intentionally without substantive content.

F - 2 
HNF-2230 Rev. 0

\section{APPENDIX G - SURVEILLANCE AND MAINTENANCE PLAN}

As with Appendix $F$ this Appendix $G$ is a placeholder for the final S\&M Plan, to be developed, negotiated with, and approved by the ERC during Phase II, Task 1.1. The interim monitoring plan developed during Phase I for use by WMH during Phase II should serve as a lead-in to this S\&M Plan.

$\mathrm{G}-1$ 
HNF-2230 Rev. 0

This page intentionally without substantive content.

$\mathrm{G}-2$ 


\begin{tabular}{|c|c|c|c|c|c|}
\hline \multicolumn{6}{|c|}{ DISTRIBUTION SHEET } \\
\hline \multirow{2}{*}{$\begin{array}{l}\text { TO } \\
\text { DISTRIBUTION }\end{array}$} & \multirow{2}{*}{\multicolumn{3}{|c|}{$\begin{array}{l}\text { From } \\
300 \text { Area LEF Engineering }\end{array}$}} & \multicolumn{2}{|c|}{ Page 1 of 1} \\
\hline & & & & \multicolumn{2}{|c|}{ Date $06-24-98$} \\
\hline \multirow{2}{*}{$\begin{array}{l}\text { Project Title/Work Order } \\
300 A \text { Liquid Effluent Facility }\end{array}$} & \multirow[b]{2}{*}{ HNF -2230} & & \multirow{2}{*}{\multicolumn{2}{|c|}{$\begin{array}{ll}\text { EDT No. } & 618209 \\
\text { ECN No. } & \text { N/A } \\
\end{array}$}} \\
\hline & & & & & \\
\hline Name & MSIN & $\begin{array}{l}\text { Text } \\
\text { With All } \\
\text { Attach. }\end{array}$ & Text Only & $\begin{array}{l}\text { Attach./ } \\
\text { Appendix } \\
\text { Only }\end{array}$ & $\begin{array}{c}\text { EDT/ECN } \\
\text { Only }\end{array}$ \\
\hline CENTRAL FILES & $\mathrm{B} 1-07$ & $x$ & & & \\
\hline $\begin{array}{l}\text { RB BARMETTLOR } \\
\text { LD BERNESKI } \\
\text { JF BECKSTROM } \\
\text { VW BRIGGS, JR. } \\
\text { MW CLAYTON } \\
\text { SB GARNETT } \\
\text { DL HALGREN } \\
\text { DW LINDSEY } \\
\text { SS LOWE } \\
\text { RM MILLIKIN } \\
\text { AG MISKHO } \\
\text { WA PEIFFER } \\
\text { DR SCHELL } \\
\text { LD STEFANSKI } \\
\text { RT STORDEUR } \\
\text { KJ SVOBODA } \\
\text { RM SZELMECZKA }\end{array}$ & $\begin{array}{l}L 6-04 \\
L 6-04 \\
L 6-40 \\
P 7-63 \\
L 6-05 \\
L 6-05 \\
L 6-04 \\
T 3-01 \\
H 6-29 \\
L 5-65 \\
H 6-23 \\
S 6-15 \\
L 6-05 \\
S 6-15 \\
L 6-40 \\
N 1-26 \\
L 6-05\end{array}$ & 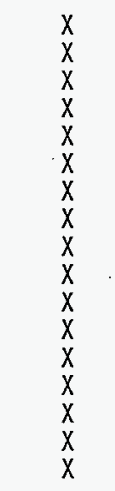 & & & \\
\hline
\end{tabular}

